Curso de Pós-graduação em

Ciência dos Alimentos

\title{
VALOR NUTRICIONAL DA BIOMASSA DE Saccharomyces cerevisiae. ESTUDO EM GERAÇÕES SUCESSIVAS DE RATOS
}

SILVIA MARIA FRANCISCATO COZZOLINO

\author{
Tese para obtenção do título de \\ DOUTOR \\ Orientador: \\ Prof. Dr. SÉRGIO MIGUEL ZUCAS
}


Ao meu marido

Federico

$e$ aos meus filhos

Flävia e ciro. 
Aos meus pais sylvio e Nexme. 


\section{AGRADECIMENTOS}

- Ao Proj. Dr. Sērgio Miguel zucas, pela amizade e orientação deste trabalho.

- Ao Prof. Dr. Franco M. Lajolo, pelo apoio recebido.

- A Prob. Dra. Marilene De Vuono Camargo Penteado, pela amizade, interesse e auxilio prestados.

- A Prof. Dra. Lor Cury, pelo interesse demonstrado em relação ao nosso trabalho.

- Ao CNPa pela bolsa de pesquisa concedida.

- A FINEP, pelos auxilios recebidos.

- A Federico cozzolino Projetos Estruturais, pela elaboração dos gräficos e fotos.

- Aos colegas do Departamento de Alimentos e Nutrição Experi mental, que sempre nos apoiaram.

- Ao João da Penha e Inês Maria Henrique, pelos auxilios téc nicos prestados.

- A Loanda d'Eurydice e Benedita E. S. de Oliveira, pelos ser viços prestados. 


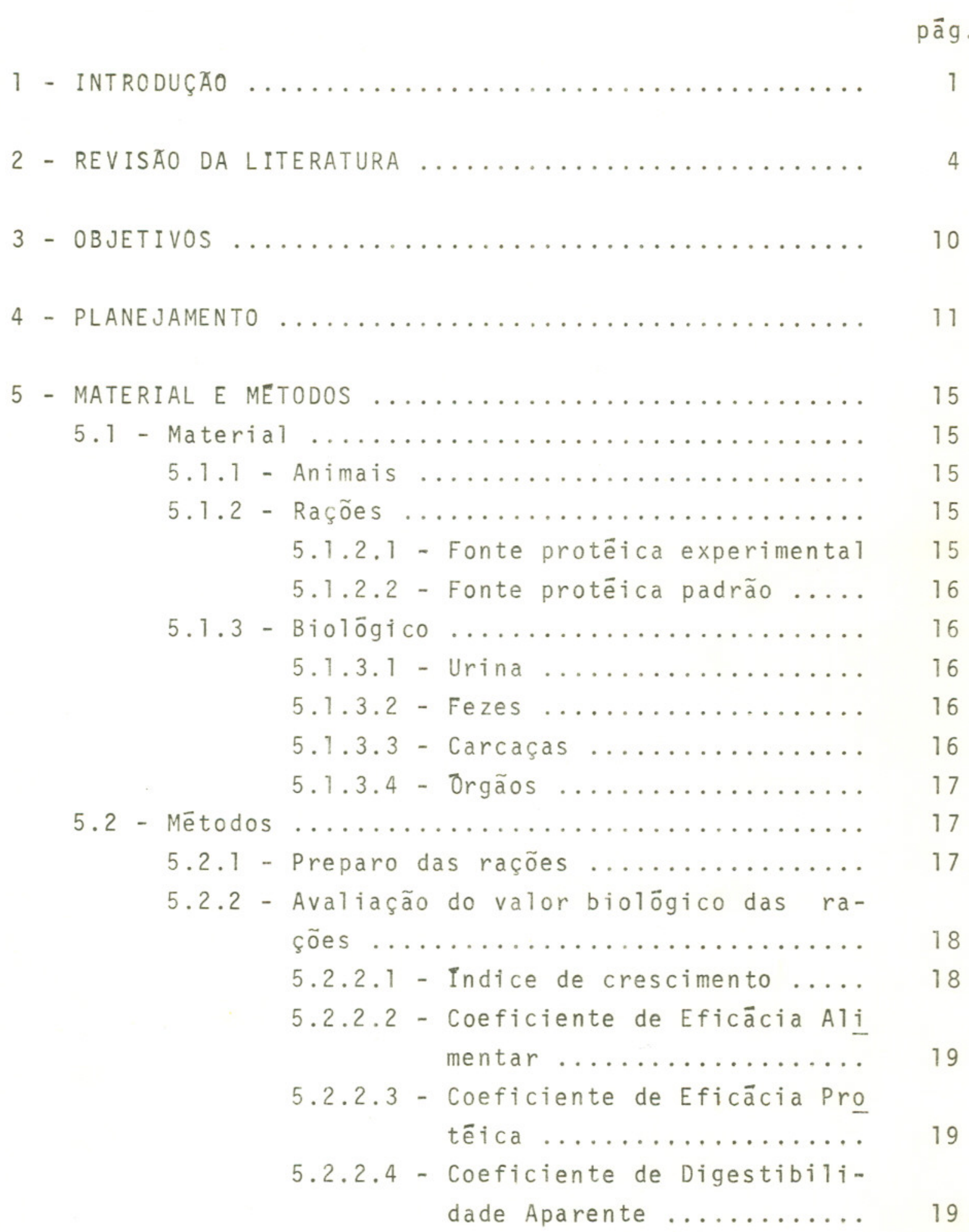


pāg.

5.2.2.5 - Valor Biológico Aparente...

5.2.2.6 - Utilização Protêica Lĩquida Aparente .............. 20

5.2.3 - Anālise das Rações e Biomassa ...... 20

5.2.3.1 - Umidade ............... 20

5.2 .3 .2 - Cinzas .............. 20

5.2 .3 .3 - Extrato etēreo ........... 21

5.2 .3 .4 - Nitrogênio total ....... 21

5.2.3.5 - Aminograma da Biomassa.... 21

5.2 .4 - Anālise dos örgãos .............. 22

5.2.4.1 - Proteinas totais ......... 22

5.2.4.2 - Lipides totais .......... 22

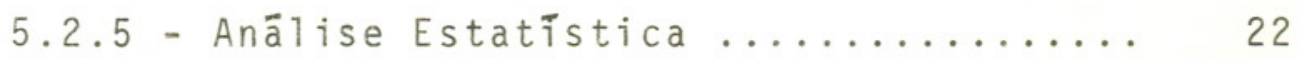

6 - ANÁlise e discussão dos Resultados ............... 23

6.1 - Composição da Biomassa .................. 23

6.1 .1 - Composição Centesimal ............ 23

6.1.2 - Composição aminoacídica da proteĩna da biomassa ................... 24

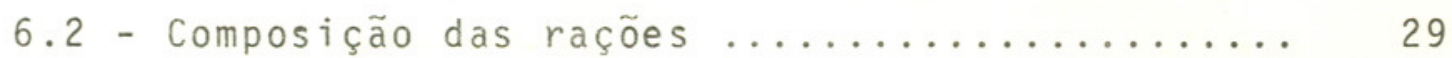

6.3 - Valor biolögico da proteina da biomassa no en saio preliminar de curta duração ............ 6.3.1 - Resultados do valor biolögico das rações ............................ 34

6.3 .2 - Resultados da anālise dos örgãos .... 48

6.4 - Resultado do valor nutricional da biomassa no estudo de longa duração ................ 53

6.4.1 - Resultados de Fertilidade ......... 55

6.4 .2 - Resultados do valor biolögico da proteîna da biomassa em estudos de gera-

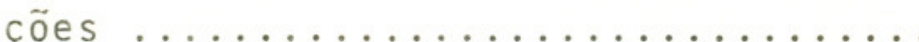

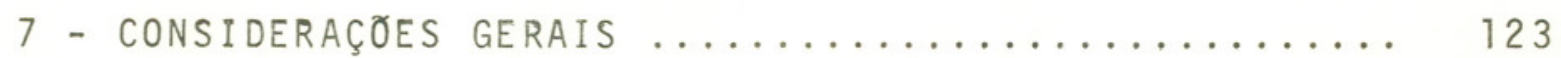

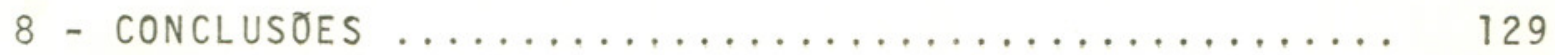

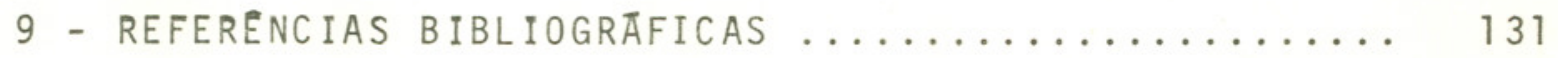

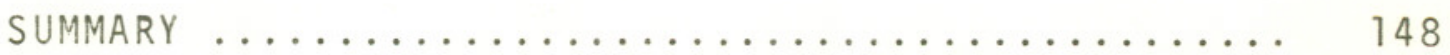


1 - INTRODUÇÃO

Neste final de século, quando os progressos alcançados pela Ciência, especialmente na ārea de Nutrição, vieram contribuir para uma me lhoria das condições de saūde das popula ções de muitos países, ainda defrontamos com problemas de certa gravidade nos paises em desenvolvimento.

As consequências da ingestão insuficiente de alimentos, ou mesmo de uma dieta desequilibrada são amplamente conhe cidas, refletindo seus efeitos negativos no desempenho dos indivĩduos no âmbito da sociedade, o que sem dūvida influencia o desenvolvimento do pais.

No Brasil, têm-se conhecimento atravēs de inquēritos alimentares, que grande parte da população não recebe a quanti dade mīnima de calorias e nutrientes necessārios para o seu bom desenvolvimento ${ }^{(42)}$.

Assim, uma das grandes preocupações dos örgãos gover namentais è equacionar uma precāria agricultura, aliada a uma deficiente indūstria alimentar, para obter alimentos em quantidade e qualidade suficientes para suprir as necessidades da população. (85)

Paralelamente, as estatísticas mundiais demonstram, que os indices de crescimento populacional continuam subindo, e previsões para um futuro prōximo têm mostrado que haverā fạ 
ta de alimento, constituindo portanto, um alerta às autorida des prepostas a resolverem este problema $(7)(15)(21)(63)(115)$ (120).

Dentre os programas que visam dar solução a esta crị se destacam-se alēm do incremento da agricultura, atravēs da modernização das tēcnicas convencionais de obtenção de alimentos e da aplicação dos resultados de pesquisas na área de gené tica vegetal, tambëm o processamento de alimentos, principal mente atravēs da industrialização, permitindo um maior tempo de estocagem, diminuindo consequentemente as perdas $(7)(15)(36)$ $(100)$.

Por outro lado, existem ainda outros alimentos, tambēm chamados de "não convencionais", que embora utilizados por certos grupos populacionais desde épocas remotas, não são sufi cientemente difundidos, e, por is to mesmo, pouco conhecidos. Dentre estes destacam-se as fontes oriundas de microorganismos, que devido à grande facilidade de obtenção, com custos de produção relativamente baixos comparados aos de outros alimentos convencionais, tornam-se um grande atrativo para os setores $1 \underline{i}$ gados à àrea economica (4)(95).

Entretanto, a introdução destes alimentos na alimentação humana e animal, tem causado sērias controvērsias, indicando que hā necessidade de estudos mais detalhados quanto ao seu valor nutricional e sua inocuidade.

Foi devido a este fato, que nos propusemos a estuar esta fonte alternativa de alimentos, em particular a biomas sa protéica obtida a partir de Saccharomyces cerevisiae em me- 
laço da cana de açūcar, em escala industrial, contribuindo para o melhor conhecimento desta fonte protēica quanto às suas propriedades nutricionais. 
Os microorganismos foram introduzidos na alimentação humana hä milênios, quando iniciou-se o processamento de bebi das alcoōlicas, queijos e panificação(19)(21)(94).

Dentre os microorganismos utilizados na alimentação tanto humana como animal, destacam-se vārios gêneros e espécies de bactērias, algas, leveduras e fungos (21)(93)(94).

Entretanto, foi somente a partir da I e II Guerras Mundiais, que as leveduras particularmente, foram estudadas com finalidade de suplemento protéico, a fim de melhorar as dietas deficientes daquele periodo $(15)(18)(19)(21)(56)(70)(99)$.

os fatores preponderantes para a utilização desta fon te não convencional de proteîna, estão baseados na peculiaridade dos microorganismos de se reproduzirem rapidamente, pode rem utilizar os mais diferentes tipos de substrato, podendo ser controlados laboratorialmente, tornando-se portanto independentes de fatores ambientais ou climāticos, alēm de possuirem um alto teor de proteinas e vitaminas $(55)(62)(67)(68)(91)(94)(106)(114)$ $(119)(123)(124)$.

Por outro lado, hā algumas desvantagens, pois sendo resíduos de células, as biomassas contém elevado teor de àcidos nucleicos, podendo causar problemas na eliminação de àcido ürico proveniente do metabolismo das purinas, conforme am- 
plamente discutido em värios trabalhos $(73)(78)(88)(91)(99)(127)$ e por não se conhecer atē o momento, qual a influência do uso contīnuo com possíveis fatores tóxicos ou alergênicos.

Quimicamente, esta varia de acordo com o tipo de microorganismo empregado, bem como das condições de crescimento.

Tomaremos como base de referência as leveduras, que constituiram o motivo de nossa pesquisa.

Quanto ao teor de proteina bruta (nitrogênio $\times 6,25$ ), têm-se para as leveduras uma variação de 50 a $70 \%(19)(94)(99)$ (109), porēm nem todo nitrogênio encontra-se sob a forma de proteĩna, estabelecendo-se atravēs de värios trabalhos a cifra de aproximadamente $20 \%$ para nitrogênio não protēico, derí vado de ácidos nucleicos e outros constituintes (1)(19)(25)(62)(63) (68)(93)(94)(106)(123).

Quanto à composição aminoacídica, estas se mostram deficientes em sulfurados totais, contendo um alto teor de lisina, parecendo-se portanto, com as proteínas de leguminosas $(19)(27)$ $(62)(93)(94)(118)(123)$.

Em relação aos minerais, as leveduras apresentam alta porcentagem de cinzas, da ordem de 6 a $9 \%$ baseada em peso seco, sendo aproximadamente a metade constituída por fosfatos, encontrando-se tambēm sais de $\mathrm{Ca}, \mathrm{K}, \mathrm{Mg}, \mathrm{Na} \mathrm{eSO}_{3}(19)(62)(94)$ (106)(119)(123).

Quanto às vitaminas, são excelentes fontes de vitami nas do complexo B, com exceção da vitamina $B_{12}$. Segundo vārios autores, as quantidades obtidas variaram na dependencia do meio de crescimento, por exemplo, num meio enriquecido com 
tiamina, os valores encontrados para esta vitamina foram maiores $(94)(112)(119)$. Contêm tambëm pequena quantidade de vitami na E e prō vitamina D. A maioria das leveduras não contêm vitami na $A$, nem $\beta$-caroteno, existindo entretanto, algumas espēcies que constituem exceções $(19)(94)$.

o teor de gordura obtido atravēs de extração com solventes orgânicos, varia de 1 a $2 \%$ para a maioria das espécies. A natureza destas substâncias não tem sido determinada, embora existam estudos indicando ācidos graxos e substāncias in saponificāveis(19). Alguns resultados tambëm indicaram que o meio de cultura influencia o conteūdo de gordura, que aumenta quando o meio ē rico em açūcares.

Os carboidratos estão presentes sob a forma de glico gênio e a fibra bruta ē representada pelas substâncias da pare de celular(19).

Nos Estados Unidos, o uso de leveduras ē disciplinado por uma legislação, que especifíca as quantidades mínimas para os nutrientes. Esta legislação foi publicada pelo Natio nal Formulary em 1970, apresentando os seguintes valores: umidade, māximo de $7 \%$; cinzas, māximo de $8 \%$; proteîna bruta ( $N$ x 6,25), mínimo de 45\%; tiamina, mīnimo de $120 \mu \mathrm{g} / \mathrm{g}$; riboflavina, mīnimo de $40 \mu \mathrm{g} / \mathrm{g}$; niacina, mīnimo de $300 \mu \mathrm{g} / \mathrm{g}$; bactērias vi vas, māximo de $7.500 / g$; bolor vivo, mäximo de $50 / g$. (94)

Biologicamente, analisando-se o valor nutricional da proteỉna da biomassa, vārios experimentos foram realizados com animais e no ser humano. Os animais utilizados foram aves domésticas, ratos, cachorros, porcos, coelhos, vacas, macacos, 
peixes de lago e outros, chegando-se à conclusão atravēs dos resultados obtidos, que esta fonte alimentar produzia bons resultados, quando utilizada em substituição a parte da proteĩna da ração $(10)(80)(94)(101)(102)$.

Em 1968, BRESSANI fêz uma revisão da literatura, de 1910 a 1968, sobre o valor nutricional de proteínas derivadas de leveduras, obtidas de värios tipos de substratos, chegando à conclusão que estas proteĩnas tinham um valor biolōgico infe rior ao esperado, com deficiências de aminoācidos sulfurados; ressaltando tambēm, que a adição de levedura a uma dieta con vencional, poderia melhorar o valor nutricional desta, atravēs da complementação dos aminoācidos (19).

Em tērmos gerais, as experiências realizadas com leveduras não apresentaram resultados muito divergentes quanto ao valor nutricional, entretanto o tipo de levedura empregada,bem como o meio de crescimento utilizado para sua propagação, podem influenciar os resultados (19)(63)(123).

As primeiras experiências com leveduras realizadas no ser humano, não alcançaram grande sucesso, por produzirem sintomas ligados a desconforto gastro-intestinal, diarrēias e vômitos sem causa comprovada, surgindo hipóteses de que este fato poderia ser devido ao processamento tecnológico empregado para sua obtenção(18)(43)(44)(70)(99)(117).

Outras pesquisas demonstraram, que a ingestão de leveduras em pequena quantidade, não causou anormalidades na maio ria dos indivíduos que serviram como voluntārios nestas expe riēncias (64), entretanto indivĩduos mais sensīveis, apre - 
sentaram sinais de intolerāncia logo apōs as primeiras doses( ${ }^{(99)}$. Os trabalhos realizados no ser humano, visando a relação existente entre ingestão de leveduras e eliminação de ācido ūrico, demonstraram que hā correlação positiva, e tal fato poderia levar à produção de gota em pessoas jă predispostas geneticamente, bem como aumentar o risco para aquelas que não o fossem $(17)(32)(58)(121)(122)$ Neste sentido, värios pesquisadores tem procurado obter biomassas com teores reduzidos de ācidos nucléicos. Os métodos utilizados tem produzido bons resultados, embora o custo de produção seja algumas vezes inviāvel $(22)(26)(57)(74)(83)(103)(104)$.

Foi neste sentido, que o grupo FAO/OMS/UNICEF inte ressado em proteinas, passou a discutir os limites de segurança que deveriam ser respeitados, ao introduzir esta fonte protēica não convencional na alimentação humana ou animal. Foram propostos estudos controlados e ao mesmo tempo foram agrupados os conhecimentos na ārea, estabelecendo-se desde a primeira reunião, que a quantidade de äcidos nucleicos não deveria ultrapassar o limite de $2 \mathrm{~g}$ por dia, para um indivïduo adulto nor mal, sendo ainda mais reduzida, quando administrada a crianças $(6)(33)(51)(52)(87)$.

Sabe-se que alëm dos problemas normais para obtenção da biomassa; que deve ser controlada em todas as fases pelas quais o microorganismo passa, atē a fase final; e do teor de ācidos nucleicos; um outro fator de preocupação, estā na utili zação de substratos como hidrocarbonetos, que podem deixar resīduos nas cēlulas, tornando-se portanto, impröprias para con- 
sumo humano(21). Por outro lado, a utilização destas biomas sas em rações animais deve ser feita com cuidado, a fim de que a ingestão de carnes, ovos e leite destes animais pelo ser humano, não causem contaminação indireta.

POKROVSKY(93) relata que em experimentos utilizando animais alimentados com biomassas contendo cerca de $2 \%$ de hidrocarbonetos residuais, estes apresentaram alterações principalmente no fígado e rins, recomendando que mesmo para rações animais, a taxa de hidrocarbonetos residuais não deve exceder $0,1 \%$.

Na maioria dos experimentos realizados com leveduras, empregando-se vārias espēcies e diferentes meios de cultura, não ficou demonstrado problemas de toxicidade nem para o homem, nem para os animais experimentais, mesmo quando em estudos de longa duração $(5)(14)(19)(92)(110)$ entretanto como citado por OSER (88) as Nações Unidas estabeleceram que:

"Antes que um alimento seja oferecido para utilização humana, deve-se ter certeza, da inocuidade e qualidade do alimento manufaturado pelos processos sugeridos. Mas, mesmo com a maior das precauções, qualquer nova fonte de proteîna, precisa ser testada primeiro no homem, em escala limitada, com observa ções cuidadosas, a fim de se identificar qualquer pos sivel risco insuspeito". 
3 - OBJETIVOS

Estudar o valor nutricional da biomassa, obtida a par tir de Saccharomyces cerevisiae em melaço de cana de açūcar, em escala industrial, no desenvolvimento de ratos em gerações sucessivas.

3.1 - Verificar a influência do nível protēico da biomassa a $10 \%$ e $25 \%$, no desenvolvimento de ratos em gerações sucessivas.

3.2 - Verificar o comportamento dos animais frente à gestação e lactação.

3.3 - Verificar possiveis fatores tóxicos advindos da ingestão de biomassa, como única fonte protēica na ração, durante um perīodo de longa duração. 
4 - Planejamento

Nosso trabalho foi realizado em duas etapas, a primeira foi constituīda de um ensaio biolögico preliminar de cur ta duração, para avaliarmos o valor nutricional da fonte pro tēica escolhida, a fim de justificarmos os ensaios posteriores, e a segunda etapa foi realizada para verificar o comportamento desta fonte por um longo perīodo de tempo.

No ensaio preliminar utilizamos 30 ratos, sendo 15 fêmeas e 15 machos, divididos da seguinte forma:

$$
\begin{array}{r}
\text { Grupo zero - } \\
\text { meas, que foram sacrificados no inīcio da ex- } \\
\text { periência, para anālise de carcaça e örgãos. }
\end{array}
$$
Grupo de biomassa - constituĩdo por 12 ratos, 6 ma- chos e 6 fēmeas.
Grupo de caseina _ constituĩdo por 12 ratos, tambēm 6 machos e 6 fëmeas.

Portanto, a fonte protéica experimental foi consti tuĩda pela biomassa e a fonte proteíca padrão pela caseína. 
Os animais foram mantidos em gaiolas metabōlicas individuais, por um período de 28 dias, onde coletou-se urina e fezes. Ao final da experiēncia, todos os animais foram sacrificados, suas carcaças foram secas e desengorduradas e os örgãos foram congelados e mantidos à temperatura de $-18^{\circ} \mathrm{C}$ (freezer).

Na fase complementar, selecionamos 72 ratos, 54 fê meas e 18 machos, que foram colocados em gaiolas pröprias para criação, na proporção de 3 fêmeas para cada macho, e mantidos acasalados por 5 dias, devido ao ciclo estral da rata ser de 4 dias (81)(105). Apōs este periodo, os machos foram retirados e as fêmeas foram mantidas juntas atē o final da gestação, quan do então foram separadas, pouco antes do nascimento dos filhotes. Logo apōs o nascimento, o total das ratas com filhotes foi dividido em 4 grupos, aos quais foram administrados rações experimentais; portanto jā na fase de lactação as ratas recebe ram rações de: caseĩna e biomassa, aos nîveis protéicos de 10\% e $25 \%$ cada uma.

Entre os 25 e 30 dias de vida, os filhotes foram des mamados e iniciou-se o experimento com a primeira geração.

Cada grupo ficou constituīdo de 12 fëmeas e 6 machos, somando-se portanto 72 animais, que foram mantidos ate a fase adulta (com cerca de 120 dias), sendo então cruzados entre si para obtenção da 20 Geração.

Após o acasalamento os machos foram sacrificados, e seus örgãos foram congelados e conservados para anālises.

Os filhotes foram mantidos com suas respectivas maẽs atē o desmame, e foi iniciada a 2a. Geração. Nesta fase, cada 
grupo de animais foi subdividido em dois, sendo um para repro dução e outro para sacrifícios aos 30,60 e 90 dias de vida.

Os grupos para reprodução foram compostos de 4 fêmeas e 2 machos, e os grupos para sacrifícios de 9 animais no mỉnimo.

Na fase adulta, fêz-se novo acasalamento para obten ção da 3a. Geração, novamente foram separados 9 animais de ca da grupo para sacrificios aos 30,60 e 90 dias de vida.

Na pāgina 14 apresentamos o fluxograma do planeja mento. 


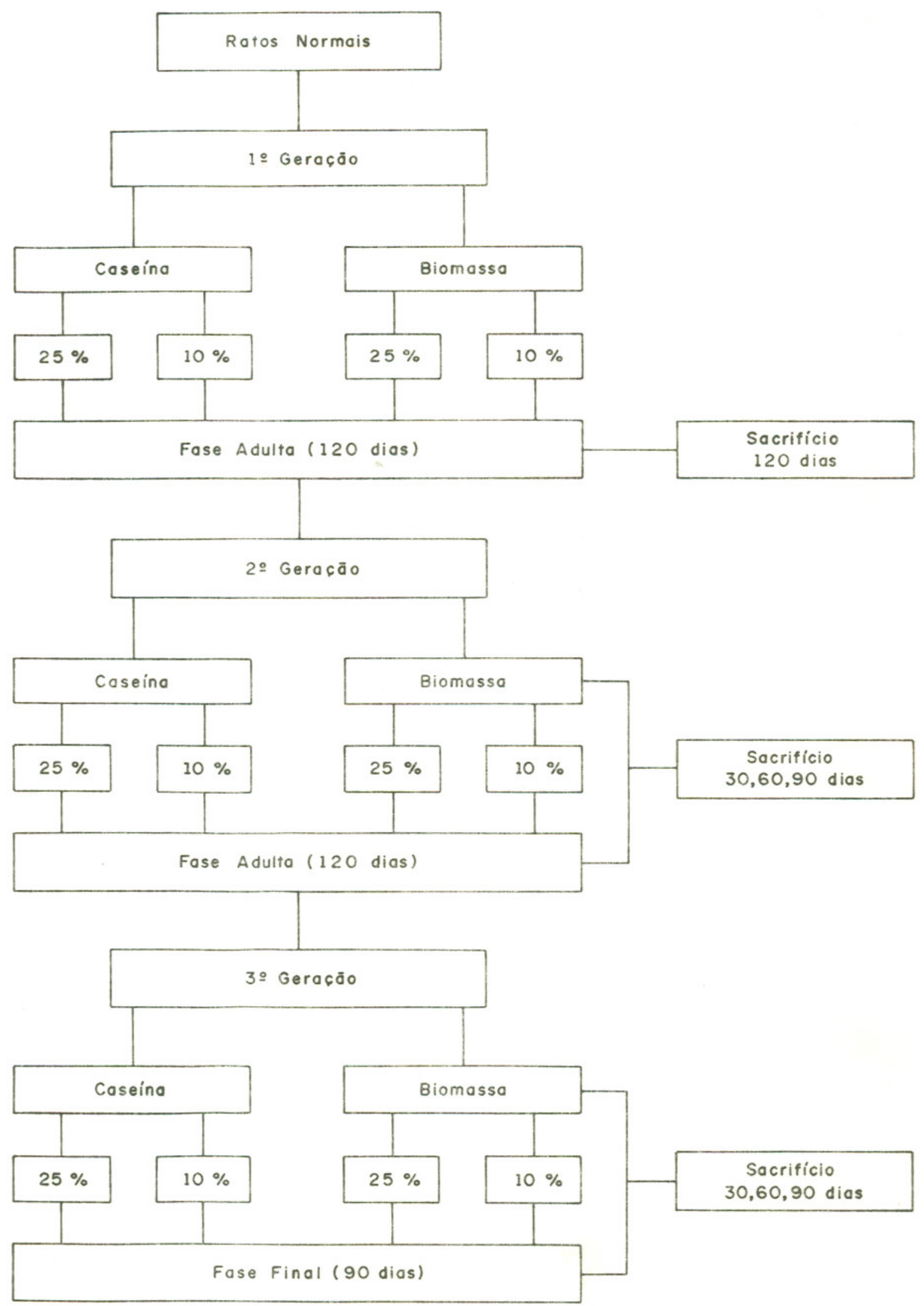


5 - material e metodos

5.1 - Material

5.1 .1 - Animais

Utilizamos em nosso experimento ratos albinos, da li nhagem Wistar (Rattus norvergicus, var. albinus, Rodentia, Mam malia) provenientes do Biotērio da Faculdade de Ciências Farma cêuticas da USP.

5.1 .2 - Rações

As rações estudadas foram nutricionalmente balanceadas, testadas aos nĩveis protëicos de $10 \%$ e $25 \%$.

5.1.2.1 - Fonte protëica experimental

Como fonte protêica experimental utilizamos a biomas sa, obtida a partir de Saccharomyces cerevisiae em melaço de cana de açūcar, em escala industrial.(84) 


\subsubsection{2 - Fonte protēica padrão}

Como fonte protēica padrão, utilizamos a caseina, ad quirida no comērcio de São Pauto.

\section{$5.1 .3-$ Biológico}

$$
5.1 .3 .1-\text { Urina }
$$

A urina dos animais submetidos aos diferentes tratamentos, no ensaio preliminar de curta duração, foi coletada diariamente, sendo mantida em pH ac̄ido e em geladeira, atē o final do experimento, para anālise de nitrogênio total.

\section{$5.1 .3 .2-$ Fezes}

As fezes foram coletadas com intervalos de 2 dias, tambēm durante o experimento de curta duração, sendo conservadas no estado seco para anālise de nitrogênio total.

\section{1 .3 .3 - Carcaças}

Ao final do periodo experimental de curta duração, os animais foram sacrificados, suas carcaças foram pesadas, se cas, desengorduradas e pulverizadas para anālise de nitrogê nio total. 


\section{$5.1 .3 .4-$ Orgãos}

Os cërebros e fígados dos animais tanto do periodo ex perimental de 28 dias, como dos demais grupos experimentais sub sequentes, foram retirados no momento do sacrifício, pesados, imediatamente congelados em nitrogênio líquido e conservados a $-18^{\circ} \mathrm{C}$ para anālises posteriores.

\section{2 - Métodos}

\subsection{1 - Preparo das rações}

As rações controle e experimental foram preparadas se gundo as normas do Departamento de Alimentos e Nutrição Experí mental da Faculdade de Ciências Farmacêuticas da USP, que se baseiam na mistura dos componentes na proporção indicada pelo quadro 1, sendo transformados em massa por meio da goma de ami do e àgua. Esta massa foi transformada em granulado vermicu lar e dessecada a $60^{\circ} \mathrm{C}$ em estufa ventilada.

As misturas salina e vitaminica encontram-se descritas em trabalho anterior dos autores $(29)$ e basearam-se nas necessidades do rato(81)(105) 
QUADRO 1 - Composição percentual bäsica das rações

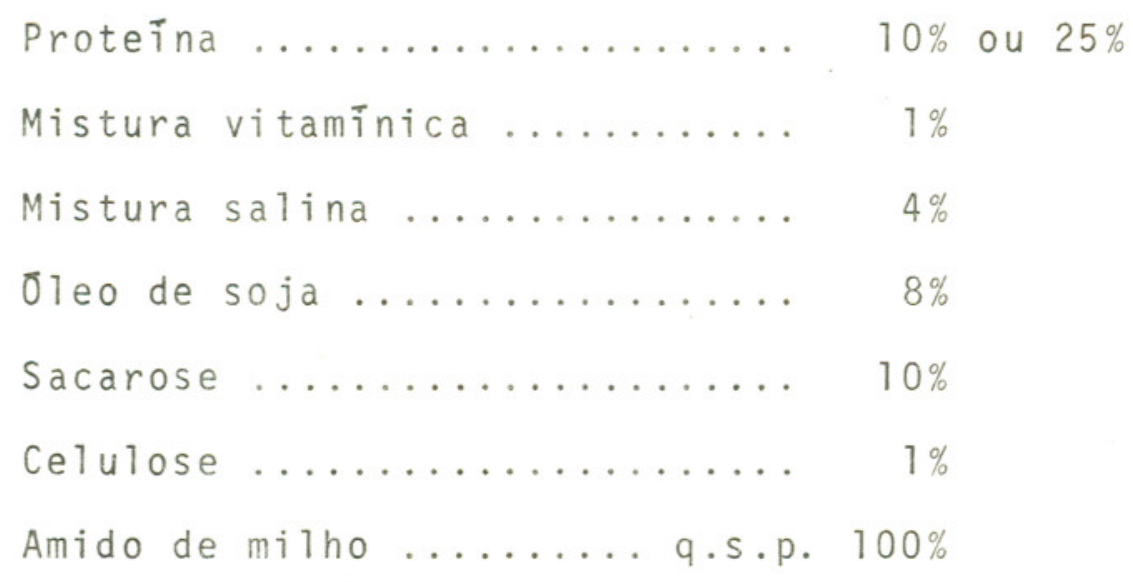

5.2.2 - Avaliação do valor biolögico das rações

Para avaliação do valor biolögico das rações, foram utilizados os seguintes indices:

\subsubsection{1 - Indice de crescimento (I.C.)}

Para determinação do indice de crescimento dos animais submetidos aos diferentes tratamentos, estes foram pesa dos semanalmente durante o período experimental. A mëdia dos resultados de cada grupo nas diferentes semanas, demons tra a eficācia da ração em relação ao aumento de peso corporal dos animais. 
5.2.2.2 - Coeficiente de Eficäcia Alimentar ( CEA )

As diferenças de peso corporal dos animais, podem estar relacionadas à quantidade de ração ingerida, portanto, con trolando-se o ganho de peso dos animais e o consumo de ração, poderemos determinar o coeficiente de eficácia alimentar, que representa o aumento de peso do animal por grama de ração inge rida.

5.2.2.3 - Coeficiente de Eficäcia Protēica (CEP)

o coeficiente de eficācia protëica è o indice de valor biológico mais utilizado em ensaios com animais, embora atualmente existam algumas modificações neste método, permitin do avaliações mais rápidas(13). Representa o aumento de peso do animal por grama de proteína ingerida.

$$
\begin{gathered}
\text { 5.2.2.4 - Coeficiente de Digestibilidade Apa } \\
\text { rente (C.Dap.) }
\end{gathered}
$$

As proteinas possuem diferentes graus de digestibili dade. Atravēs do balanço entre a quantidade de nitrogênio ingerido e excretado pelas fezes, teremos o nitrogênio absorvido, cuja porcentagem em relação ao ingerido nos darā o coeficiente de digestibilidade aparente. 


$$
5.2 .2 .5 \text { - Valor biológico aparente (V.Bap.) }
$$

o valor biolögico aparente calcula-se em função da quantidade de nitrogēnio retido pelo animal. Pode-se calcular atravēs do ba.lanço nitrogenado ou da anälise da carcaça, e a porcentagem de nitrogēnio retido em relação ao nitrogênio absorvido nos darā o V.B ap.

$$
\begin{gathered}
5.2 .2 .6 \text { - Utilização Protēica Lĩquida Aparen } \\
\text { te (UPL ap.) }
\end{gathered}
$$

A utilização protēica lîquida aparente, também calcula-se em função da quantidade de nitrogēnio retido pelo animal, entre tanto relaciona-se percentualmente com a quantidade de nitrogê nio ingerido.

\subsection{3 - Anälise das Rações e Biomassa}

$$
5.2 .3 .1 \text { - Umidade }
$$

A determinação da umidade foi realizada por gravimetria em estufa regulada a $105^{\circ} \mathrm{C}$, até peso constante ${ }^{(60)}$.

\subsubsection{2 - Cinzas (Residuo mineral fixo)}

A determinação de cinzas foi realizada por gravime tria, em mufla a $550^{\circ} \mathrm{C}$, até peso constante $(60)$. 


\subsubsection{3 - Extrato Etēreo}

A fração extrato etēreo foi determinada em extrator intermitente de Soxhlet, utilizando-se ëter etïlico como sol vente $(60)$.

\subsubsection{4 - Nitrogênio total}

0 teor de nitrogēnio total foi determinado atravēs do mëtodo de Microkjeldahl (8), utilizando-se o fator 6,25 para transformação deste em proteīna.

\subsubsection{5 - Aminograma da Biomassa}

O aminograma da biomassa foi realizado na Escola Pau lista de Medicina, em analisador automātico.

0 mëtodo empregado, baseou-se na hidrōlise äcida do material segundo STEWART e YOUNG(107).

Para determinação do triptofano, utilizou-se hidrölise específica segundo LIU e CHANG(69).

As determinações de metionina e cistina, foram reali zadas na Faculdade de Ciências Farmacêuticas da USP, utilizando-se o mëtodo de MOORE ${ }^{(76)}$. 
5.2 .4 - Anālise dos örgãos

$$
\text { 5.2.4.1 - Proteinas totais }
$$

Para determinação de proteỉnas totais no fĩgado e cẹ rebro utilizamos o mëtodo de Microkjeldahl ${ }^{(8)}$.

$$
\text { 5.2.4.2 - Lïpides Totais }
$$

Os lipides totais no fígado foram determinados utili zando-se o método de FOLCH et cols. (41).

\subsection{5 - Anālise Estatīstica}

A anālise estatisstica foi realizada utilizando-se a Anālise de Variância Multivariada desenvolvida por WILKS (125), e a significância do teste $F$ verificada a nível de $0,1,1$ e $5 \%$ de probabilidade, no Centro de Computação Eletrônica da USP. Calculou-se o desvio padrão, que foi representado nas tabelas precedido do sinal \pm . 
6 - AnÁlise e discussão dos resultados

os resultados obtidos neste experimento encontram-se nas Tabelas de 1 a 41 e nas Figuras de 1 a 34.

\section{1 - Composição da Biomassa}

\section{1 .1 - Composição Centesimal}

De acordo com o que pudemos observar atravēs da lite ratura e descrito no inīcio do presente trabalho, a biomassa obtida a partir de leveduras, pode apresentar uma composição centesimal, cuja variação está na dependência do tipo de levedura empregada, bem como do meio de crescimento.

A biomassa utilizada em nosso estudo, foi obtida a partir de Saccharomyces cerevisiae, utilizando como substrato o melaço de cana de açūcar, e analisada apresentou a seguin te composição centesimal: umidade 5,3; cinzas 7,3; extrato etê reo 2,0; proteína bruta $(N \times 6,25) 51,2$; fração NIFEXT (incluindo a fração fibra) 35,2 .

Verificamos que tais valores, estão em concordāncia 
com as especificações para alimentos derivados de leveduras, apresentando quantidade significativa de proteína.

\subsection{2 - Composição aminoacídica da proteîna da bio- massa}

Como jā sabemos, os aminoācidos presentes na fração protéica de uma determinada fonte de proteína, caracteri zam o valor biolögico da mesma. Os diversos autores que estudaram proteinas derivadas de leveduras, obtiveram resultados semelhantes, principalmente no que diz respeito ao excesso de lisina e deficiência em sulfurados totais.

o aminograma da proteína de biomassa utilizada em nosso experimento, encontra-se na Tabela 1.

A anālise da Tabela 1 , demonstra que os resultados ob tidos encontram-se dentro dos parāmetros previstos para esta fonte alimentar.

Por outro lado, sabemos tambēm que o valor biolögico de uma proteína não depende exclusivamente do seu aminograma, uma vez que a quantidade total de aminoācidos essenciais, rela cionada com o teor total de nitrogēnio da proteína, pode nos indicar a capacidade da mesma em construir tecido, que $\vec{e}$ em ūltima anālise o objetivo bāsico a ser atingido.

Assim sendo, procuramos analisar atravēs do cômputo quîmico dos aminoácidos, que traduz o interrelacionamento entre os aminoäcidos essenciais e a relação E/T, as limitações 
TABELA 1 - Teor em aminoācidos ( $/ 100 \mathrm{~g}$ de proteīna) presentes na proteína da biomassa, determinado através do emprego de analisador automático (Cozzolino, 1982).

\begin{tabular}{|c|c|}
\hline Aminoācido Teor & g/100g de Proteína \\
\hline Lisina & 9,09 \\
\hline Histidina & 2,60 \\
\hline Arginina & 5,20 \\
\hline Triptofano & 1,04 \\
\hline Ácido Aspārtico + Asparagina & 10,70 \\
\hline Treonina & 4,79 \\
\hline Serina & 4,75 \\
\hline Acido Glutâmico + Glutamina & 19,81 \\
\hline Prolina & 3,65 \\
\hline Glicina & 4,81 \\
\hline Alanina & 6,20 \\
\hline $1 / 2$ Cistina & 1,23 \\
\hline Valina & 6,07 \\
\hline Metionina & 1,96 \\
\hline Isoleucina & 4,57 \\
\hline Leucina & 6,51 \\
\hline Tirosina & 3,16 \\
\hline Fenilalanina & 3,89 \\
\hline Total & 100,03 \\
\hline
\end{tabular}


da proteỉna da biomassa em relação à proteīna do ovo, proteîna do leite (caseina) e proteīna provisional da F.A.0*. Os resul tados obtidos encontram-se nas Tabelas 2 e 3 .

A anālise destas tabelas demonstra que dependendo do padrão utilizado, os amino ācidos limitantes primārio, secundārio e terciārio tambëm se modificaram. Assim, comparan do-se a proteîna da biomassa com a proteina do ovo, verifica mos pelo cômputo quîmico atravēs da relação A/E (Tabela 2) e percentual (Tabela 3), uma limitação primäria de sulfurados tó tais, da ordem de $33,6 \%$ e $44,9 \%$ respectivamente, seguidos de triptofano, da ordem de $13,8 \%$ e $30,2 \%$ e de aromáticos totais, da ordem de $13,5 \%$ e $28,7 \%$.

A relação existente entre proteina da biomassa e pro teīna provisional da F.A.0, tambēm indicam pelas mesmas determinações anteriores, os sulfurados totais como limitantes primārios, da ordem de $22,7 \%$ e $8,9 \%$, seguidos de leucina, da ordem de $20,6 \%$ e $7,0 \%$ e finalmente triptofano, da ordem de 10,7\%, não havendo limitação quando calculado pela relação percentual. A comparação com a proteína do leite (caseĩna), apre sentou uma limitação primäria para aromāticos totais, da ordem de $24,1 \%$ e $37,5 \%$, seguidos de triptofano, da ordem de $21,9 \%$ e $37,0 \%$ e finalmente leucina, da ordem de $18,5 \%$ e $33 \%$. Verificamos neste caso, que a biomassa utilizada, não apresen tou limitação em aminoácidos sulfurados, fato perfeitamente com preensīvel, pois a caseīna, embora utilizada comumente como pa

${ }^{\star}$ F.A.0 - Food Agricultural Oranization 
TABELA 2 - Teor em aminoācidos, relação A/E e cômputo quīmico dos aminoācidos essenciais da proteîna da Biomassa, em relação ä proteína do ovo, proteína do leite e proteína provisio nal da FAO (COZZOLINO, 1982).

\begin{tabular}{|c|c|c|c|c|c|c|c|c|}
\hline \multirow{2}{*}{ Aminoācidos } & \multicolumn{2}{|c|}{ Biomassa } & \multicolumn{2}{|c|}{$0 \vee 0$} & \multicolumn{2}{|c|}{ Caseina $(35)$} & \multicolumn{2}{|c|}{$F A O(37)$} \\
\hline & $\begin{array}{l}\mathrm{g} / 100 \mathrm{~g} \\
\text { protein na }\end{array}$ & $A / E$ & $A / E$ & Computo & $A / E$ & Cômputo & $A / E$ & Cômputo \\
\hline Isoleucina & 4,57 & 108 & 123 & 87,8 & 108 & 100,0 & 111 & 97,3 \\
\hline Leucina & 6,51 & 154 & 172 & 89,5 & 189 & $81,5^{\star \star \star}$ & 194 & $79,4^{\star \star}$ \\
\hline Lisina & 9,09 & 215 & 136 & 158,1 & 162 & 132,7 & 153 & 140,5 \\
\hline Fenil-alanina & 3,89 & 92 & 112 & 82,1 & 104 & 88,5 & - & - \\
\hline Tirosina & 3,16 & 75 & 81 & 92,6 & 116 & 64,7 & - & - \\
\hline Aromāticos totais & 7,05 & 167 & 193 & $86,5^{\star \star \star}$ & 220 & $75,9^{\star}$ & 167 & 100,0 \\
\hline Metionina & 1,96 & 46 & 66 & 69,7 & 56 & 82,1 & - & - \\
\hline $1 / 2$ Cistina & 1,23 & 29 & 47 & 61,7 & 7 & 414,3 & & $-\ldots$ \\
\hline Sulfurados totais & 3,19 & 75 & 113 & $66,4^{\star}$ & 63 & 119,0 & 97 & $77,3^{*}$ \\
\hline Treonina & $4,7,9$ & 113 & 100 & 113,0 & 93 & 121,5 & 111 & 107,8 \\
\hline Triptofano & 1,04 & 25 & 29 & $86,2^{\star *}$ & 32 & $78,1^{* *}$ & 28 & $89,3^{* * *}$ \\
\hline Valina & 6,07 & 144 & 134 & 107,5 & 134 & 107,5 & 139 & 103,6 \\
\hline Total & 42,48 & & & & & & & \\
\hline
\end{tabular}

\footnotetext{
*aminoäcido limitante primärio

** aminoācido limitante secundārio *** aminoäcido limitante terciārio
}

$$
\frac{A}{E}=\frac{m g \text { do aminoācido essencial }}{\text { total de aminoàcidos essenciais }}
$$


TABELA 3 - Teor em aminoācidos essenciajs (g/100g proteīna), cômputo quĩmi co percentual e relação E/T dos aminoācidos da proteína da biomassa em relação à proteína do ovo, proteína do leite e a proteîna provisional da FAO (COZZOLINo, 1982)

\begin{tabular}{|c|c|c|c|c|c|c|c|}
\hline \multirow{2}{*}{ Aminoācidos } & \multirow{2}{*}{$\begin{array}{c}\text { Biomassa } \\
\text { g/100g } \\
\text { proteina }\end{array}$} & \multicolumn{2}{|c|}{$0 \vee 0$} & \multicolumn{2}{|c|}{ Caseína } & \multicolumn{2}{|c|}{$\begin{array}{lll}\mathrm{A} & \mathrm{O}\end{array}$} \\
\hline & & $\begin{array}{c}\mathrm{g} / 100 \mathrm{~g} \\
\text { proteina }\end{array}$ & Cômputo & $\begin{array}{c}\mathrm{g} / 100 \mathrm{~g} \\
\text { proteína }\end{array}$ & Cômputo & $\begin{array}{c}\mathrm{g} / 100 \mathrm{~g} \\
\text { proteina }\end{array}$ & Cōmputo \\
\hline Isoleucina & 4,57 & 6,29 & 72,7 & 5,52 & 82,8 & 4,0 & 114,3 \\
\hline Leucina & 6,51 & 8,82 & 73,8 & 9,71 & $67,0^{* \star *}$ & 7,0 & $93,0^{* *}$ \\
\hline Lisina & 9,09 & 6,98 & 130,2 & 8,29 & 109,7 & 5,5 & 165,3 \\
\hline Fenilalanina & 3,89 & 5,73 & 67,9 & 5,34 & 72,8 & - & - \\
\hline Tirosina & 3,16 & 4,16 & 76,0 & 5,94 & 53,2 & - & - \\
\hline Aromäticos totais & 7,05 & 9,89 & $71,3^{\star \star \star}$ & 11,38 & $62,5^{\star}$ & 6,0 & 117,5 \\
\hline Metionina & 1,96 & 3,36 & 58,3 & 2,85 & 68,8 & - & - \\
\hline $1 / 2$ Cistina & 1,23 & 2,43 & 50,6 & 0,37 & 332,4 & - & - \\
\hline Sulfurados totais & 3,19 & 5,79 & $55,1^{*}$ & 3,22 & 99,1 & 3,5 & $91,1^{*}$ \\
\hline Treonina & 4,79 & 5,12 & 93,6 & 4,75 & 100,8 & 4,0 & 119,8 \\
\hline Triptofano & 1,04 & 1,49 & $69,8^{* \star}$ & 1,65 & $63,0^{* *}$ & 1,0 & 104,0 \\
\hline Valina & 6,07 & 6,85 & 88,6 & 6,88 & 88,2 & 5,0 & 121,4 \\
\hline Total & 42,28 & 51,23 & & 51,30 & & 36,0 & \\
\hline$E / T$ & 2,64 & 3,20 & & 3,20 & & 2,25 & \\
\hline
\end{tabular}

*aminoācido limitante primärio **aminoācido limitante secundārio ***aminoācido limitante terciārio

\footnotetext{
$\underline{E}=$ total de aminoācidos essenciais
} 
drão, è deficiente nestes aminoācidos, recomendando-se inclusi ve a adição de metionina como suplemento em ensaios biolögicos. Quanto à relação E/T dos aminoäcidos, representada na Tabela 3 , verificamos que o resultado obtido para a proteína da biomassa $(2,64)$ foi inferior ao da proteina do ovo $(3,20)$ e do leite $(3,20)$; entretanto foi superior ao da proteina provisional da F.A.O $(2,25)$. Outros autores encontraram relações $E / T$ de 2,94 a 3,26 para biomassas obtidas de vārias espēcies de le veduras (19).

Portanto, a partir destes resultados, podemos concluir que a proteína da biomassa utilizada, apresentou limitações moderadas de alguns aminoācidos essenciais, principalmente de sulfurados totais, quando comparada à proteína do ovo e proteina provisional da F.A.O. Os teores de lisina foram significantes, mostrando a importância do estudo desta fonte protēica em complementação alimentar.

Esta anālise, vem reforçar as considerações anteriores, em concordância com a maioria dos trabalhos jā citados anteriormente.

\section{2 - Composição das Rações}

Como sabemos, a introdução de uma nova fonte alimen tar, tanto para animais como para seres humanos, deve ser racionalmente estudada e planejada, e estes estudos devem conter resultados obtidos atravës dos insumos que entram nesta 
nova fonte de alimentos.

No presente caso, estamos estudando a biomassa obtida de Saccharomyces cerevisiae como fonte de proteína, e que deve ser analisada quanto à sua inocuidade, valor nutricional, con dições sanitārias, aceitabilidade e propriedades tecnológicas.

Evidentemente, dentro dos parâmetros acima citados, procuramos estudar os aspectos de inocuidade e valor nutricio nal. Este ültimo, diz respeito não tão somente ao que foi ex posto com relação ao estudo da composição química da biomassa,co mo tambēm aos ensaios biológicos que devem se suceder.

Neste particular, procuramos estudar o valor biológico em ratos, e associamos este estudo aos testes de inocuidade prē-clīnicos, através de geraçöes sucessivas de ratos.

Para que este estudo se efetivasse, procuramos preparar rações isocalöricas e isonitrogênicas, aos nīveis protéicos de $25 \%$ e $10 \%$, tomando-se como referéncia protēica a caseîna.

As rações, preparadas de acordo com o îtem 5.2.1, apōs anālise, apresentaram a composição percentual contida nas Tabelas 4 e 5 .

Os dados da Tabela 4, referem-se à composição das rações do experimento de curta duração, e os da Tabela 5, às de longa duração.

Pode-se observar através destas tabelas, que as rações controle e experimentais, apresentaram-se de acordo com 0 esperado, diferindo apenas quanto ao teor de cinzas, fato que não pode ser evitado, pois a anāilise da biomassa, como jā des- 
TABELA 4 - Composição percentual das rações de caseĩna e biomassa, ao nível protéico de $10 \%$, utilizadas no ensaio pre liminar de curta duração. (COzZOLINo, 198?).

$\begin{array}{rrr} & & \\ \text { RAÇAOO UMIDADE } & \text { CINZA } & \text { ETEREO }\end{array}$

CASEINA

$10 \%$

$\begin{array}{llll}4,3 & 3,9 & 7,9 & 10,8\end{array}$

B I OMASSA

$10 \%$

$4,3 \quad 5,0$

8,0

10,3 
TABELA 5 - Composição percentual das rações de caseĩna e biomassa, aos nỉveis protēicos de $25 \%$ e $10 \%$, utilizados no experimento de longa duração. (COzzolino, 1982).

\begin{tabular}{|c|c|c|c|c|}
\hline Ração & Umidade & Cinza & $\begin{array}{l}\text { Extrato } \\
\text { Etēreo }\end{array}$ & Proteína \\
\hline $\begin{array}{c}\text { Caseína } \\
25 \%\end{array}$ & 5,0 & 4,2 & 8,5 & 26,5 \\
\hline $\begin{array}{c}\text { Biomassa } \\
25 \%\end{array}$ & 5,2 & 7,2 & 9,2 & 26,0 \\
\hline $\begin{array}{c}\text { Caseĩna } \\
10 \%\end{array}$ & 4,4 & 4,0 & 8,0 & 10,8 \\
\hline $\begin{array}{c}\text { Biomassa } \\
10 \%\end{array}$ & 4,4 & 5,1 & 8,6 & 10,7 \\
\hline
\end{tabular}


crito anteriormente, apresentou 7,3\% para esta fração.

Quanto ao valor calōrico das rações, verificamos que todas continham cerca de $400 \mathrm{kcal}$ para cada $100 \mathrm{~g}$.

\section{3 - Valor biológico da proteina da biomassa no ensaio preliminar da curta duração}

o valor biológico de uma proteîna não está condicionado apenas ao seu aspecto químico, pois sabemos que uma determinada proteína pode conter todos os aminoācidos em quantidade adequada para a espécie a que se destina, sem entretanto ser perfeitamente utilizada a nivel celular. Assim os experimen tos biológicos, contribuem para uma anāilise complementar do va lor biológico desta proteína.

os indices utilizados para esta avaliação, conforme jā descritos anteriormente no item 5.2.2, tem sido revistos por muitos autores, que procuram aprimorā-los cada vez mais, objeti vando resultados mais fidedignos $(12)(13)(34)$.

A determinação do valor biológico da proteīna da bio massa, bem como das análises dos örgãos, para o período experimental de curta duração, encontram-se nas Tabelas de 6 a 15 . 


\subsection{1 - Resultados do valor biolögico das raçöes}

Utilizamos neste ensaio, rações contendo cerca de $10 \%$ de proteina, a fim de que todo o nitrogênio presente, fosse destinado para fins plàsticos, pois sabemos que o excedente das necessidades proteícas do animal, quando não utilizado para sua função primāria de construção de tecidos, da mesma for ma que em relação aos lîpides e carboidratos, será transformado em calorias e posteriormente em gordura de reserva, uma vez que o organismo não possue reserva protéica.

Na Tabela 6 , apresentamos os resultados de ganho de peso dos animais, coeficientes de eficācia alimentar e protéica, calculados em função do consumo de ração e proteîna respectivamente.

Analisando esta tabela, podemos verificar que o ga nho de peso dos animais foi semelhante para todos os grupos, en tretanto, sabemos que o indice de crescimento, embora muito utilizado como indicador do valor biológico de uma proteína, se analisado separadamente do consumo de ração e de proteîna não traz resultados muito significantes.

Assim, quando levamos em consideração o consumo de ração, analisando-se o coeficiente de eficācia alimentar (CEA), verificamos que os grupos apresentaram comportamentos diferentes. A anāise estatistica demonstrou que a comparação entre os grupos de fêmeas alimentadas com rações de caseĩna e biomassa, apresentaram valores diferentes para este indice, ao 
TABELA 6 - Médias e desvio padrão do ganho de peso, consumo de ração, coeficiente de efí cácia alimentar (CEA), consumo de proteína, coeficiente de eficácia protēica (CEP), dos animais alimentados com ração controle de caseĩna e ração experimental de biomassa, ao nível protéico de $10 \%$, durante 28 dias de experiēncia. (COZZOLINO, 1982).

\begin{tabular}{|c|c|c|c|c|c|c|c|c|}
\hline \multirow{2}{*}{ GRUPOS } & \multirow{2}{*}{ SEXO } & \multicolumn{2}{|c|}{$\operatorname{PESO}(\mathrm{g})$} & \multirow{2}{*}{$\begin{array}{c}\text { GANHO } \\
\text { DE PESO } \\
(\mathrm{g})\end{array}$} & \multirow{2}{*}{$\begin{array}{c}\text { RAÇĀO } \\
\text { INGERIDA } \\
(\mathrm{g})\end{array}$} & \multirow{2}{*}{ CEA } & \multirow{2}{*}{$\begin{array}{c}\text { PROTEINA } \\
\text { INGERIDA } \\
(\mathrm{g})\end{array}$} & \multirow{2}{*}{ CEP } \\
\hline & & INICIAL & FINAL & & & & & \\
\hline \multirow{4}{*}{$\begin{array}{c}\text { CASEINA } \\
10 \%\end{array}$} & \multirow[t]{2}{*}{$0^{\pi}$} & 38,6 & 125,6 & 87,0 & 266,4 & 0,327 & 28,8 & 3,025 \\
\hline & & $\pm 2,2$ & $\pm 16,6$ & $\pm 15,1$ & $\pm 44,0$ & $\pm 0,019$ & $\pm 4,8$ & $\pm 0,182$ \\
\hline & \multirow{2}{*}{ q. } & 39,2 & 128,6 & 89,4 & 285,3 & 0,313 & 30,8 & 2,901 \\
\hline & & $\pm 2,7$ & $\pm 13,3$ & $\pm 12,1$ & $\pm 32,7$ & $\pm 0,017$ & $\pm 3,5$ & $\pm 0,159$ \\
\hline \multirow{4}{*}{$\begin{array}{l}\text { BIOMASSA } \\
10 \%\end{array}$} & \multirow[t]{2}{*}{$0^{\pi}$} & 38,8 & 126,8 & 88,0 & 286,7 & 0,306 & 30,7 & 2,866 \\
\hline & & $\pm 2,1$ & $\pm 10,6$ & $\pm 9,8$ & $\pm 25,1$ & $\pm 0,014$ & $\pm 2,7$ & $\pm 0,131$ \\
\hline & \multirow[t]{2}{*}{ 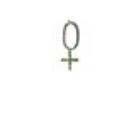 } & 39,6 & 123,7 & 84,1 & 319,6 & 0,264 & 34,2 & 2,467 \\
\hline & & $\pm 2,7$ & $\pm 10,9$ & $\pm 9,8$ & $\pm 20,3$ & $\pm 0,033$ & $\pm 2,2$ & $\pm 0,309$ \\
\hline
\end{tabular}


nīvel de 1\% de significāncia, sendo superior para o grupo de ca seína. Por outro lado, este grupo apresentou maior consumo de ração quando comparado aos demais grupos, tal fato contraria o previsto, pois geralmente, quando uma ração possue limitações em nutrientes, existe uma tendência do animal, no sentido de in gerir menor quantidade de alimento. Com estes resultados, pode mos concluir que houve um menor aproveitamento da ração para este grupo de animais.

o consumo de proteîna é outro dado importante, pois alēm de estar relacionado ao efeito de consumo de ração, a anālise química destas rações, também pode apresentar pequenas variações, que influem no resultado final.

Portanto, a partir da quantidade de proteina ingerida pelos animais, podemos determinar o coeficiente de eficácia protēica (CEP), que possibilita a análise representativa do aproveitamento da proteîna para fins biológicos.

Pela anālise dos nossos resultados, verificamos que os grupos de biomassa, apresentaram indices inferiores aos dos grupos controle de caseīna, tanto para o coeficiente de eficácia alimentar (CEA) como para o coeficiente de eficācia protéica $(C E P)$.

'Anteriormente, a anālise quỉmica dos aminoácidos, de monstrou que comparativamente à proteina da caseina, a da bio massa apresentou 1 imitações moderadas de aminoācidos essenciais, entretanto, como jā sabemos, uma proteína pode conter todos os aminoācidos essenciais em quantidade adequada e apresentar ba $\underline{i}$ xo rendimento biológico, devido a problemas de digestibilidade, 
motivo pelo qual analisamos tambëm o coeficiente de digestibili dade aparente das rações.

Na Tabela 7 , procuramos estudar a quantidade de nitrogênio eliminado nas fezes dos animais, e verificamos que aqueles alimentados com ração de biomassa, eliminaram praticamente o dobro de fezes dos animais do grupo controle de caseîna. A anälise estatística destes resultados mostrou diferença signifí cativa ao nível de $0,1 \%$.

A partir destes dados, calculamos o coeficiente de di gestibilidade aparente das rações (Tabela 8 ), e verificamos que os valores obtidos foram superiores para a ração controle de ca seīna em relação à ração experimental de biomassa, da ordem de $90 \%$ e $80 \%$, respectivamente.

Estes resultados estão em concordāncia com värios autores que trabalharam com diferentes tipos de leveduras, obtendo resultados que variaram de 75 a $92 \%(20)(25)(31)(39)(48)$.

Portanto, os resultados anterioremtne descritos para CEA e CEP, podem ser explicados atravēs deste coeficiente, mostrando que realmente houve um menor aproveitamento protëico das rações de biomassa.

Procuramos tambēm avaliar o coeficiente de eficäcia protëica real, a partir do nitrogēnio absorvido das rações e portanto disponível para a sintese protëica animal (Tabela 9). 
TABELA 7 - Médias e desvio padrão da quantidade de fẹ zes eliminadas, porcentagem de nitrogênio nas fezes e total de nitrogênio eliminado, dos animais alimentados com ração controle de caseina e experi mental de biomassa, ao nivel protéico de $10 \%$, durante 28 dias de experiência. (COZZOLINo, 1982).

\begin{tabular}{|c|c|c|c|c|}
\hline \multirow[t]{3}{*}{ GRUPOS } & SEXO & $\begin{array}{c}\text { FEZES } \\
\text { DESSECADAS } \\
(\mathrm{g})\end{array}$ & $\% \quad \mathrm{~N}$ & $\begin{array}{c}\text { TOTAL DE } \\
\text { ELIMINA } \\
(\mathrm{g})\end{array}$ \\
\hline & $0^{7}$ & 12,0 & 3,78 & 0,46 \\
\hline & & $\pm 1,2$ & $\pm 0,18$ & $\pm 0,05$ \\
\hline
\end{tabular}

CASEINA

$10 \%$

$q$

13,5
$+\quad 1,6$

3,68

0,50

1,6

$\pm 0,17$

$\pm 0,08$

$0^{7}$

24,2
$\pm \quad 1,8$

4,15

1,03

$\pm 0,16$

$\pm 0,09$

BIOMASSA

$10 \%$

$\begin{array}{rrr}24,3 & 4,08 & 0,99 \\ \pm 8,6 & \pm 0,24 & \pm 0,07\end{array}$


TABELA 8 - Médias e desvio padrão do nitrogënio ingerido, nitrogênio fecal, nitrogênio absorvido e coeficien te de digestibilidade aparente, dos animais alimenta dos com ração controle de caseỉna e experimental de biomassa, ao nīvel protēico de $10 \%$, durante 28 dias de experiēncia (COZZOLINO, 1982).

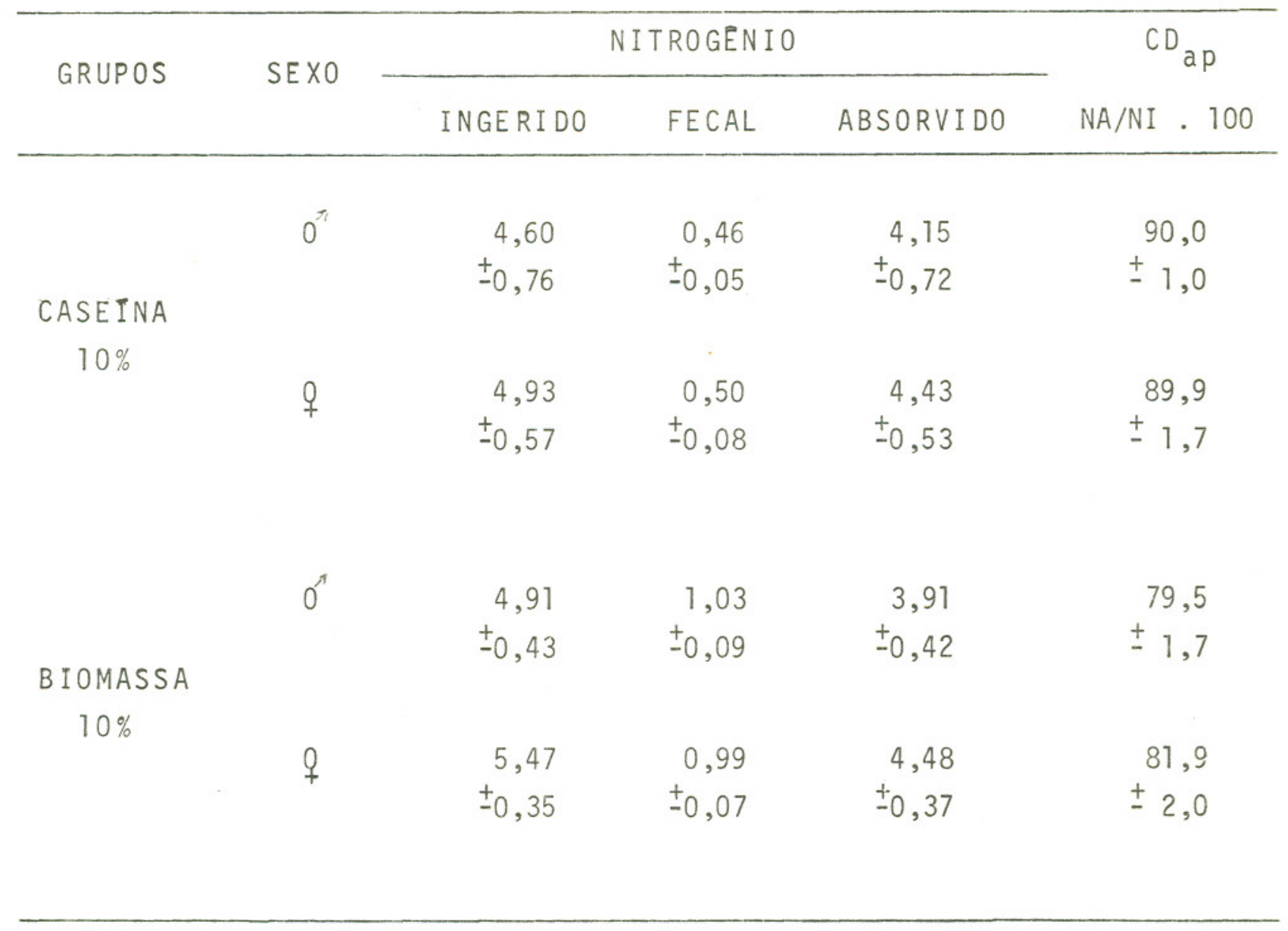

$N A=$ nitrogēnio absorvido

NI = nitrogēnio ingerido

$C D_{\text {ap }}=$ coeficiente de digestibilidade aparente 
TABELA 9 - Médias e desvio padrão do ganho de peso, coeficiente de digestibilidade aparente $\left(C D_{a p}\right)$, proteīna ingerida e absorvida, coeficiente de eficäcia protēi ca (CEP) e coeficiente de eficäcia protēica real (CEP real), dos animais alimen tados com ração controle de caseĩna e experimental de biomassa, ao nīvel pro tēico de 10\%, durante 28 dias de experiência. (COZZOLIno, 1982).

\begin{tabular}{|c|c|c|c|c|c|c|c|}
\hline \multirow{2}{*}{ GRUPOS } & \multirow{2}{*}{ SEXO } & \multirow{2}{*}{$\begin{array}{l}\text { GANHO } \\
\text { PESO } \\
(\mathrm{g})\end{array}$} & \multirow{2}{*}{$C D_{\text {ap }}$} & \multicolumn{2}{|c|}{ PROTEINA (g) } & \multirow{2}{*}{ CEP } & \multirow{2}{*}{${ }^{C E P_{\text {real }}}$} \\
\hline & & & & Ingerida & Absorvida & & \\
\hline \multirow{5}{*}{$\begin{array}{c}\text { CASEINA } \\
10 \%\end{array}$} & \multirow[t]{2}{*}{$0^{-1}$} & 87,0 & 90,0 & 28,8 & 25,9 & 3,025 & 3,359 \\
\hline & & $\pm 15,1$ & $\pm 1,0$ & $\pm 4,8$ & $\pm 4,3$ & $\pm 0,182$ & $\pm 0,202$ \\
\hline & & & & & & & \\
\hline & \multirow{2}{*}{$q$} & 89,4 & 89,9 & 30,8 & 27,7 & 2,901 & 3,227 \\
\hline & & $\pm 12,1$ & $\pm 1,7$ & $\pm 3,5$ & $\pm 3,2$ & $\pm 0,159$ & $\pm 0,176$ \\
\hline \multirow{4}{*}{ BIOMASSA } & \multirow[t]{2}{*}{0} & 88,0 & 79,5 & 30,7 & 24,4 & 2,866 & 3,605 \\
\hline & & $\pm 9,8$ & $\pm 1,7$ & $\pm 2,7$ & $\pm 2,2$ & $\pm 0,131$ & $\pm 0,165$ \\
\hline & \multirow{2}{*}{$q$} & 84,1 & 81,9 & 34,2 & 28,0 & 2,467 & 3,012 \\
\hline & & $\pm 9,8$ & $\pm 2,0$ & $\pm 2,2$ & $\pm 1,8$ & $\pm 0,309$ & $\pm 0,376$ \\
\hline
\end{tabular}


Os resultados contidos na Tabela 9 , mostram valores superiores para o grupo de animais machos alimentados com ração de biomassa e inferiores para as fêmeas submetidas ao mesmo tratamento. Este fato sugere uma adaptação do animal, visando o melhor aproveitamento do nitrogénio presente no seu "pool" de aminoàcidos.

Como o balanço nitrogenado é outro resultado importante para avaliação do valor biológico aparente e utilizacão protēica líquida aparente da proteîna das rações, determinamos tambēm a quantidade de nitrogēnio excretado através da urina destes animais(Tabela 10), e verificamos que houve um maior vo lume de urina excretado, aumentando, consequentemente, o total de nitrogēnio eliminado.

Desta forma, pudemos calcular o valor biolōgico apa rente (VB ${ }_{a p}$ ) e utilização protēica lîquida aparente (UPL ap) das rações (Tabela 11).

Nossos resultados vieram confirmar o discutido ante riormente. Assim, verificamos novamente atravēs destes indices, a superioridade da ração controle de caseĩna em relação à ração experimental de biomassa.

A comparação dos resultados obtidos para os animais machos alimentados com rações de caseína e biomassa, mostrou valores superiores para a ração de caseîna da ordem de $7 \%$ e $13 \%$ em relação ao VB ap e UPL ap respectivamente, e os resultados obtidos para as fémeas tratadas da mesma maneira, também foram superiores para caseína da ordem de $6 \%$ e $15 \%$ para os mes mos indices. 
TABELA 10 - Médias e desvio padrão do volume de urina ex cretado e total de nitrogênio eliminado, pelos animais alimentados com ração controle de caseīna e ex perimental de biomassa, ao nível protéico de $10 \%$, du rante 28 dias de experiência. (COZZOLINo, 1982).

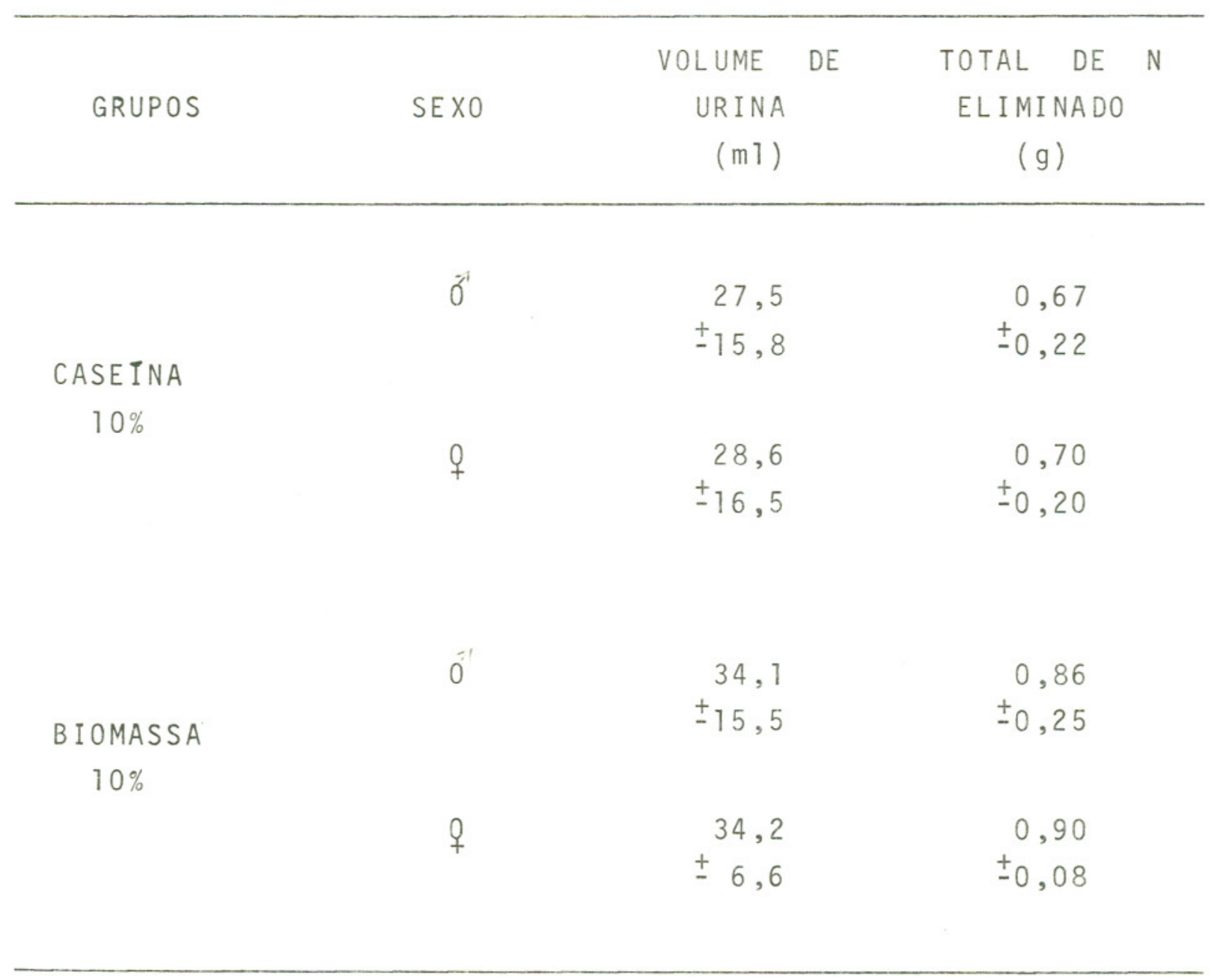


TABELA 11 - Mēdias e desvio padrão do nitrogênio ingerido, nitrogênio fecal, nitrogênio urinārio, balanço nitrogenado, do valor biolōgico aparente e utilização protēica lí quida aparente, calculados em função do balanço nitrogenado, dosanimais alimentados com ração controle de caseĩna e experimental de biomassa, ao nî́vel protēico de $10 \%$, durante 28 dias de experiência. (COZZOLINo, 1982).

\begin{tabular}{|c|c|c|c|c|c|c|c|}
\hline \multirow[b]{2}{*}{ GRUPOS } & \multirow[b]{2}{*}{ SEXO } & \multicolumn{3}{|c|}{ NITROGÊNIO } & \multirow{2}{*}{$\begin{array}{l}\text { BALANÇO } \\
\text { NITROGENADO } \\
\text { BN } \\
(\mathrm{g})\end{array}$} & \multirow{2}{*}{$\begin{array}{c}\text { VB } \\
\text { aparente }\end{array}$} & \multirow{2}{*}{$\begin{array}{c}\text { UPL } \\
\text { aparente }\end{array}$} \\
\hline & & $\begin{array}{l}\text { INGERIDO } \\
\text { NI } \\
(\mathrm{g})\end{array}$ & $\begin{array}{l}\text { FECAL } \\
\text { NF } \\
(\mathrm{g})\end{array}$ & $\begin{array}{l}\text { URINARIO } \\
\text { NU } \\
(\mathrm{g})\end{array}$ & & & \\
\hline \multirow{4}{*}{$\begin{array}{c}\text { CASEINA } \\
10 \%\end{array}$} & \multirow[t]{2}{*}{$0^{7}$} & 4,60 & 0,46 & 0,67 & 3,48 & 84,1 & 75,6 \\
\hline & & $\pm 0,76$ & $\pm 0,05$ & $\pm 0,22$ & $\pm 0,55$ & $\pm 3,3$ & $\pm 2,6$ \\
\hline & \multirow[t]{2}{*}{$q$} & 4,93 & 0,50 & 0,70 & 3,86 & 84,7 & 76,6 \\
\hline & & $\pm 0,57$ & $\pm 0,08$ & $\pm 0,20$ & $\pm 0,48$ & $\pm 4,5$ & $\pm 4,2$ \\
\hline \multirow{4}{*}{$\begin{array}{l}\text { BIOMASSA } \\
10 \%\end{array}$} & \multirow[t]{2}{*}{$0^{\pi}$} & 4,91 & 1,03 & 0,86 & 3,05 & 78,2 & 62,1 \\
\hline & & $\pm 0,43$ & $\pm 0,09$ & $\pm 0,25$ & $\pm 0,36$ & $\pm 5,3$ & $\pm 3,7$ \\
\hline & \multirow{2}{*}{$q$} & 5,47 & 0,99 & 0,90 & 3,58 & 79,8 & 65,3 \\
\hline & & $\pm 0,35$ & $\pm 0,07$ & $\pm 0,08$ & $\pm 0,37$ & $\pm 2,2$ & $\pm 2,9$ \\
\hline
\end{tabular}

$B N=N I-(N F+N U)$

$$
\begin{aligned}
V B_{a p} & =\frac{B N}{N A} \cdot 100 \\
U P L_{a p} & =\frac{B N}{N I} \cdot 100
\end{aligned}
$$


As diferenças percentuais superiores para o indice de utilização protéica lĩquida aparente são perfeitamente compreensiveis, pois este indice relaciona apenas a quantidade de nitrogēnio ingerido, sem levar em consideração o coeficiente de digestibilidade.

Vārios autores tem calculado os indices de VBap e UPL ap atravēs dos mētodos de balanço nitrogenado e anālise da carcaça, encontrando correlação positiva entre os dois métodos $(12)(20)$.

Assim, procuramos tambēm determinar estes indices, atravēs da anālise da carcaça dos animais no início e no final da experiência.

Os resultados contidos na Tabela 12 , demonstram que não houve diferenças acentuadas quanto aos teores percentuais de umidade, gordura e nitrogênio na carcaça dos animais submetidos aos diferentes tratamentos, entretanto, a quantidade total de nitrogênio na carcaça mostrou-se levemente superior para os grupos de caseina.

0 cálculo do valor biológico aparente (VBap) e utị lização protéica lĩquida aparente (UPL ${ }_{a p}$ ) das rações, atravēs da anālise da carcaça, contidos na Tabela 13, vem nos demonstrar mais uma vez, que os resultados estão coerentes com os demais indices estudados, e em concordāncia com os autores acima cita dos.

Como pudemos verificar ao analisar os resultados deste ensaio biológico preliminar, a biomassa obtida de Saccharomyces cerevisiae em melaço de cana de açūcar, segundo 
TABELA 12 - Médias e desvio padrão do peso corporal no sacrifício, peso da carcaça, \% de umidade na carcaça, \% de gordura na carcaça, \% de nitrogênio na carcaça e quantidade total de nitrogênio na carcaça dos animais alimentados com ração controle de caseỉna e ração experimental de biomassa, ao nīvel protéico de 10\%, durante 28 dias de experiência. (COZZOLINO, 1982).

\begin{tabular}{|c|c|c|c|c|c|c|c|}
\hline \multirow{2}{*}{ GRUPOS } & \multirow{2}{*}{ SEXO } & \multicolumn{2}{|c|}{ PESO } & \multicolumn{3}{|c|}{$\mathrm{g} \%$} & \multirow{2}{*}{$\begin{array}{c}\text { NITROGENIC } \\
\text { TOTAL } \\
\text { (g) }\end{array}$} \\
\hline & & $\begin{array}{l}\text { CORPORAL } \\
\text { SACRIF. } \\
\text { (g) }\end{array}$ & $\begin{array}{c}\text { CARCAÇA } \\
(\mathrm{g})\end{array}$ & UMIDADE & GORDURA & NITROGÊNIO & \\
\hline \multirow[t]{2}{*}{ ZERO } & $0^{7}$ & $\begin{array}{r}34,5 \\
\pm \quad 0,1\end{array}$ & $\begin{array}{r}24,8 \\
+\quad 1,4\end{array}$ & $\begin{array}{r}70,3 \\
\pm \quad 2,0\end{array}$ & $\begin{array}{r}7,3 \\
+2,4\end{array}$ & $\begin{array}{r}2,77 \\
\pm 0,06\end{array}$ & $\begin{array}{r}0,69 \\
\pm 0,03\end{array}$ \\
\hline & $q$ & $\begin{array}{r}34,6 \\
\pm \quad 4,2\end{array}$ & $\begin{array}{r}25,5 \\
\pm \quad 2,5\end{array}$ & $\begin{array}{r}68,5 \\
+\quad 0,9\end{array}$ & $\begin{array}{r}9,1 \\
+1,4\end{array}$ & $\begin{array}{r}2,80 \\
\pm 0,10\end{array}$ & $\begin{array}{r}0,71 \\
\pm 0,07\end{array}$ \\
\hline \multirow{2}{*}{$\begin{array}{c}\text { CASEINA } \\
10 \%\end{array}$} & 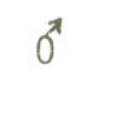 & $\begin{array}{r}125,6 \\
+\quad 16,6\end{array}$ & $\begin{array}{r}97,5 \\
+12,6\end{array}$ & $\begin{array}{r}63,1 \\
\pm \quad 3,3\end{array}$ & $\begin{array}{r}14,1 \\
\pm \quad 4,3\end{array}$ & $\begin{array}{r}2,88 \\
\pm 0,20\end{array}$ & $\begin{array}{r}2,80 \\
\pm 0,40\end{array}$ \\
\hline & 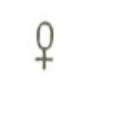 & $\begin{array}{r}128,6 \\
\pm \quad 13,3\end{array}$ & $\begin{array}{r}100,7 \\
+\quad 10,3\end{array}$ & $\begin{array}{r}60,3 \\
\pm \quad 3,6\end{array}$ & $\begin{array}{r}16,7 \\
\pm \quad 3,8\end{array}$ & $\begin{array}{r}2,90 \\
\pm 0,17\end{array}$ & $\begin{array}{r}2,93 \\
\pm 0,31\end{array}$ \\
\hline \multirow{2}{*}{$\begin{array}{l}\text { BIOMASSA } \\
10 \%\end{array}$} & $0^{2}$ & $\begin{array}{r}126,8 \\
+\quad 10,6\end{array}$ & $\begin{array}{r}97,7 \\
+\quad 9,7\end{array}$ & $\begin{array}{r}61,5 \\
\pm \quad 1,9\end{array}$ & $\begin{array}{r}16,5 \\
\pm \quad 2,5\end{array}$ & $\begin{array}{r}2,74 \\
\pm 0,10\end{array}$ & $\begin{array}{r}2,67 \\
\pm 0,19\end{array}$ \\
\hline & $q$ & $\begin{array}{r}123,7 \\
\pm \quad 10,9\end{array}$ & $\begin{array}{r}95,5 \\
\pm 10,1\end{array}$ & $\begin{array}{r}60,7 \\
+\quad 2,6\end{array}$ & $\begin{array}{r}16,8 \\
\pm \quad 3,6\end{array}$ & $\begin{array}{r}2,82 \\
\pm 0,12\end{array}$ & $\begin{array}{r}2,69 \\
\pm 0,21\end{array}$ \\
\hline
\end{tabular}


TABELA 13 - Médias e desvio padrão do valor biolōgico aparente e utilização protēica lí quida aparente, calculados em função da anālise da carcaça dos animais alimentados com ração controle de caseĩna e experimental de biomassa, ao nỉvel protéico de $10 \%$, durante 28 dias de experiência. (COZZOLINO, 1982).

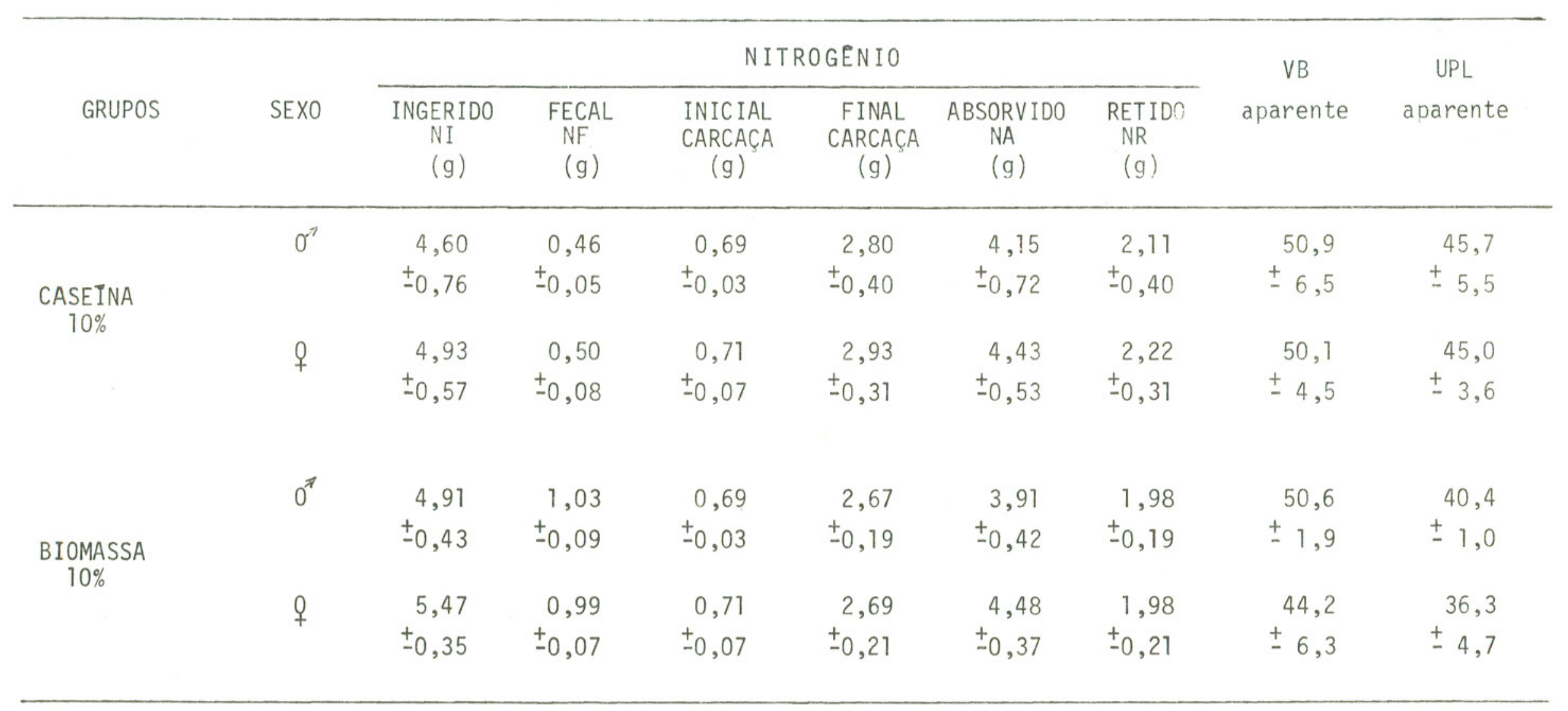

$V B_{a p}=\frac{N R}{N A} \cdot 100$
$U P L_{a p}=\frac{N R}{N I} \cdot 100$


a tecnologia utilizada( $(84)$, apresentou resultados satisfatórios neste estudo de curta duração com ratos.

Verificamos que o coeficiente de digestibilidade, que é um indice importante do valor nutricional de uma proteína foi cerca de $80 \%$, valor significativo, uma vez que sabemos que parte da quantidade de Nitrogênio ingerido é de material não protéico.

os indices relativos a crescimento, coeficiente de eficācia alimentar (CEA) e protéica (CEP), valor biolōgico aparente e utilização protéica líquida, todos indicadores do valor nutricional de uma proteina, foram ligeiramente superiores para a caseina, com pequenas variações devidas ao sexo dos animais. Entretanto, outros trabalhos de pesquisa desenvolvidos com biomassas em nosso laboratōrio, apresentaram resultados inferiores àqueles por nōs obtidos, assim MOURA (78) trabalhando com biomassa obtida de Saccharomyces, sp. em subproduto de fermentação alcoōlica, ao nîvel protēico de $8 \%$ na ração, em ratos, encontrou indices de coeficiente de eficācia alimentar (CEA) da ordem de 0,11 em 4 semanas, enquanto os nossos resultados foram de 0,31 , o mesmo podendo-se dizer em relação ao coeficiente de eficācia protēica (CEP), cujos resultados foram 1,35 contra 2,87 respectivamente.

Por outro lado, MARIATH ${ }^{(73)}$, trabalhando com isolado protēico de biomassa obtida de Saccharomyces carlbergensis em resĩduo de fermentação alcoōlica para obtenção de cerveja, ao nỉvel protēico de $10 \%$ na ração, tambēm para ratos, encontrou resultados semelhantes aos de MOURA, obtendo valores para CEA e CEP da 
ordem de 0,12 e 1,16 respectivamente, portanto tambēm inferiores aos obtidos em nossa experiēncia. Os coeficientes de digestibilidade encontrados pelos mesmos autores, foram da ordem de $70 \%$, portanto tambëm, em relação a este ĩndice, obtivemos resultados superiores.

A explicaçăo para estes resultados, poderia estar re lacionada ao tipo de levedura utilizada, bem como do processo empregado para obtenção das biomassas, uma vez que em nosso ex perimento, utilizamos uma biomassa especialmente preparada para fins alimentares, obtida em escala industrial, ao passo que as biomassas estudadas pelos autores acima citados, foram obti das de resỉduos industriais, sendo que MARIATH ${ }^{(73)}$ trabalhou com isolado protëico de biomassa obtido em escala laboratorial. Os resultados deste ensaio preliminar, serão complementados como ensaio de longa duração.

\section{3 .2 - Resultados da anālise dos ōrgãos}

A fim de avaliarmos possīveis fatores tōxicos, anali samos tambēm o fỉgado e cërebro dos animais para alguns parâmetros. Os resultados obtidos para anälise do fígado, encontram-se na Tabela 14.

A anālise desta tabela demonstra,que no perīodo estú dado, não não houve diferenças em relação ao peso do örgão e porcentagem do ōrgão em relação ao peso corporal dos animais. Este dado è muito importante em avaliações biolögicas, pois 
TABELA 14 - Médias e desvio padrão do peso do fīgado, \% de fĩgado em relação ao peso cor poral, lipides totais em mg/g de fïgado, lipides totais no fígado, proteinas totais em $\mathrm{mg} / \mathrm{g}$ de figado, proteínas totais no fígado,dos animais alimentados com ração con trole de caseĩna e experimental de biomassa, ao nỉvel protēico de 10\%, durante 28 dias de experiência. (COZZOLINo, 1982).

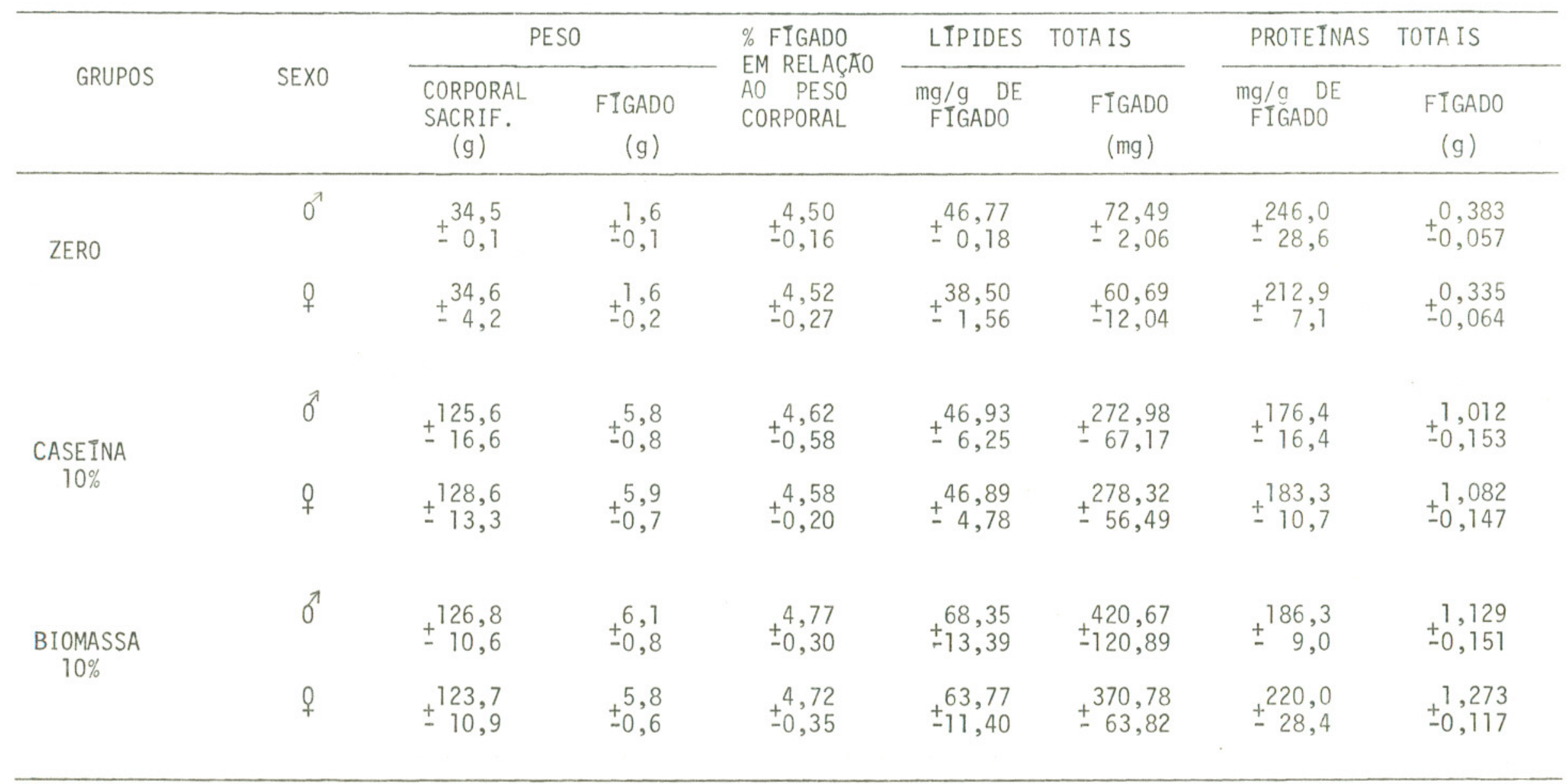


sabemos que animais desnutridos, quer em proteinas e/ou calori as, apresentam entre outras alterações, uma diminuição no peso dos örgãos $(2)(3)(9)(30)(53)(61)(72)(108)(126)(128)$. Tâl fá to não foi observado neste ensaio preliminar.

Analisamos tambēm o teor de proteinas totais e lïpides totais neste örgão, verificando que houve diferença siani ficativa em relação ao teor de lípides totais entre os animals alimentados com ração à base de caseĩna comparativamente aos de biomassa. Os valores superiores encontrados para os gru pos alimentados com a fonte protēica de biomassa, poderiam ser facilmente explicados, se a comparação entre as proteīnas da biomassa e da caseĩna tivessem apresentado deficiēncia acentua da de aminoäcidos sulfurados, fato que não ocorreu, assim neste caso, tambēm os animais alimentados com ração à base de caseỉna, deveriam apresentar este aumento.

Uma segunda hipötese para explicar este fenōmeno, po deria estar condicionada à diminuição da taxa protēica de $10 \%$ para cerca de $8 \%$ para a proteinna da biomassa, devido aos $20 \%$ de nitrogēnio não protēico, encontrado na determinação do amino grama e em concordância com a maioria dos autores pesquisados. Desta forma, uma menor disponibilidade de aminoācido para a sīntese protēica tambēm diminuiria a taxa de sỉntese de lipo protēinas de baixa densidade responsäveis pelo transporte dos triglicerídeos para fora do fïgado, acumulando-se, portanto, neste örgão(40) (71).

Em relação aos teores encontrados para proteỉnas totais, verificamos que tambēm foram superiores para os grupos 
de biomassa, principalmente no caso das fêmeas. A explicação para esta observação è difícil, porēm sabendo-se que a compo sição de um tecido estā na dependência quantitativa de outros constituintes, talvez uma alteração no teor de umidade e/ou glicogênio, poderiam ter sido responsāveis por este aumento. os estudos realizados no cērebro dos animais, (Tabe 1 a 15 ) não indicaram alterações em relação ao peso do örgão, porcentagem de ōrgão em relação ao peso corporal do animal e proteīnas totais no ōrgão.

Estes resultados jā eram esperados, pois sabemos que - cērebro do rato se desenvolve atē os 21 dias de vida(2)(126) (128), entretanto, como no experimento de longa duração, pretendemos analisar estes parāmetros, realizamos estas anāi ises, a fim de correlacionarmos os dados com este experimento inici a) 1 . 
TABELA 15 - Médias e desvio padrão do peso do cérebro, \% de cérebro em relação ao peso corpo ral, proteínas totais em $\mathrm{mg} / \mathrm{g}$ de cérebro e proteínas totais do cérebro, dos ani= mais alimentados com raçao controle de caseina e experimental de biomassa, nîvel protéico de $10 \%$, durante 28 dias de experiência. (COZZOLIN0, 1982).

\begin{tabular}{|c|c|c|c|c|c|c|}
\hline \multirow[b]{2}{*}{ GRUPOS } & \multirow[b]{2}{*}{ SEXO } & \multicolumn{2}{|c|}{ PESO } & \multirow{2}{*}{$\begin{array}{l}\% \text { CEREBRO } \\
\text { EM RELACCAO } \\
\text { AO PESO } \\
\text { CORPORAL }\end{array}$} & \multirow{2}{*}{$\begin{array}{l}\text { PROTEINAS } \\
\mathrm{mg} / \mathrm{g} \text { DE } \\
\text { CEREBRO }\end{array}$} & \multirow{2}{*}{$\begin{array}{c}\text { TOTAIS } \\
\text { CEREBRO } \\
(\mathrm{g})\end{array}$} \\
\hline & & $\begin{array}{l}\text { CORPORAL } \\
\text { SACRIF. } \\
\quad(\mathrm{g})\end{array}$ & $\begin{array}{c}\text { CEREBRO } \\
(\mathrm{g})\end{array}$ & & & \\
\hline \multirow{2}{*}{ ZERO } & $\sigma$ & $\begin{array}{r}34,5 \\
\pm \quad 0,1\end{array}$ & $\begin{array}{r}1,3 \\
\pm 0,0\end{array}$ & $\begin{array}{r}3,77 \\
\pm 0,01\end{array}$ & $\begin{array}{r}129,3 \\
\pm \quad 1,2\end{array}$ & $\begin{array}{r}0,168 \\
\pm 0,002\end{array}$ \\
\hline & 0 & $\begin{array}{r}34,6 \\
\pm \quad 4,2\end{array}$ & $\begin{array}{r}1,3 \\
\pm 0,0\end{array}$ & 3,76 & $\begin{array}{r}133,2 \\
+\quad 6,3\end{array}$ & $\begin{array}{r}0,173 \\
\pm 0,008\end{array}$ \\
\hline \multirow{2}{*}{$\begin{array}{l}\text { CASEINA } \\
10 \%\end{array}$} & 0 & $\begin{array}{r}125,6 \\
\pm \quad 16,6\end{array}$ & $\begin{array}{r}1,6 \\
\pm 0,1\end{array}$ & $\begin{array}{r}1,27 \\
\pm 0,17\end{array}$ & $\begin{array}{r}145,2 \\
\pm \quad 6,3\end{array}$ & $\begin{array}{r}0,233 \\
+0,017\end{array}$ \\
\hline & $q$ & $\begin{array}{r}128,6 \\
\pm \quad 13,3\end{array}$ & $\begin{array}{r}1,5 \\
\pm 0,0\end{array}$ & $\begin{array}{r}1,17 \\
\pm 0,12\end{array}$ & $\begin{array}{r}138,1 \\
\pm \quad 11,6\end{array}$ & $\begin{array}{r}0,207 \\
+0,017\end{array}$ \\
\hline \multirow{2}{*}{$\begin{array}{c}\text { B I OMASSA } \\
10 \%\end{array}$} & $\sigma^{\lambda}$ & $\begin{array}{r}126,8 \\
\pm \quad 10,6\end{array}$ & $\begin{array}{r}1,5 \\
\pm 0,2\end{array}$ & $\begin{array}{r}1,18 \\
\pm 0,14\end{array}$ & $\begin{array}{r}143,8 \\
+\quad 12,5\end{array}$ & $\begin{array}{r}0,215 \\
\pm 0,030\end{array}$ \\
\hline & $q$ & $\begin{array}{r}123,7 \\
+\quad 10,9\end{array}$ & $\begin{array}{r}1,5 \\
\pm 0,0\end{array}$ & $\begin{array}{r}1,21 \\
\pm 0,10\end{array}$ & $\begin{array}{r}149,4 \\
+\quad 26,2\end{array}$ & $\begin{array}{r}0,227 \\
+0,040\end{array}$ \\
\hline
\end{tabular}


6.4 - Resultado do valor nutricional da biomassa no estudo de longa duração.

Como pudemos verificar pela anāilise anterior, a fon te protéica escolhida para estudo no presente trabalho, mostrou-se de boa qualidade, justificando portanto o interesse de estudos mais prolongados, visando a possibilidade da uti lização na alimentação humana e/ou animal.

No Brasil, esta fonte protēica jā vem sendo pesqui sada hā alguns anos(23)(24)(50)(73)(79)(91)(97) demonstrando que existe grande interesse na sua utilização. Para melhor elucidar este fato, verificamos que com a crise energética mundial, a indūstria do ālcool tornou-se importante, trazendo como consequência uma disponibilidade de residuos, normalmente poluentes, que poderiam ser convertidos em fon te protéica de baixo custo.

A introdução destes produtos, na alimentação animal jāē realidade no Brasil, embora não seja muito divulgada. 
Entretanto, ressaltamos mais uma vez a importância de experimentos controlados de longa duração, conforme as recomendações dos örgãos competentes, em relação as novas fontes protéicas $(3)(6)(51) 62)$, inicialmente utilizando animais, a fim de obter-se resultados que tragam garantias de inocuidade para a espécie estudada. Posteriormente, a partir dos resultados obtidos, esta fonte poderia ser introduzida experimentalmente no ser humano, em escala reduzida, como meio de evitar possiveis efeitos adversos.

Assim, realizamos o presente estudo, conforme des crito no item planejamento em três gerações de animais.

Neste ensaio, introduzimos o teor protēico de $25 \%$ nas rações, uma vez que ao estudarmos gerações, pretendemos manter os animais dentro dos limites protēicos normalmente utilizados para manutenção, alëm de verificar possiveis fatores tōxicos, advindos do excesso de in gestão.

Portanto, nesta fase, trabalhamos com 4 grupos de an $\underline{i}$ mais, que receberam rações controle de caseĩna e experimen tais de biomassa, aos nîveis protēicos de $25 \%$ e $10 \%$, subdividi 
dos em 8 grupos, pois trabalhamos com animais machos e fêmeas. A importāncia da fonte protēica utilizada nas rações dos animais, estudada em ensaio de gerações, mostra o valor da mesma nos diferentes períodos do desenvolvimento do an mal, desde a fase intrauterina atē a fase adulta, e dependendo da ēpoca em que esta se inicia, os resultados tambēm podem variar.

Em nossos estudos, os animais da primeira geração, foram obtidos do cruzamento de ratos normais, mantidos no biotērio da Faculdade de Ciências Farmacēuticas da USP.

o inīcio do tratamento deu-se na fase de lactação, quando as ratas passaram a receber rações experimentais. Portanto, nesta fase considerada como uma das mais críticas para o desenvolvimento do rato(9)(53)(65)(77)(126), da mesma forma que para outras espēcies de animais, jā testamos a eficiência das rações.

\section{4 .1 - Resultados de Fertilidade}

Apōs o desmame, 72 animais, sendo 48 fēmeas e 24 machos, foram colocados em gaiolas individuais e mantidos com o mesmo tratamento iniciado com as suas respectivas mães, atē a fase adulta com cerca de 120 dias, sendo então cruzados entre si para obtenção da 2 a. geração.

os resultados obtidos neste cruzamento, encontram-se nas Tabelas 16 e 17. A anälise destas tabelas causou grande 
TABELA 16 - Resultados obtidos do cruzamento dos animais da la. geração, alimentados com rações de caseína e biomassa, ao nỉvel protéico de $25 \%$, até a fase adulta. (CozzoLINO, 1982)

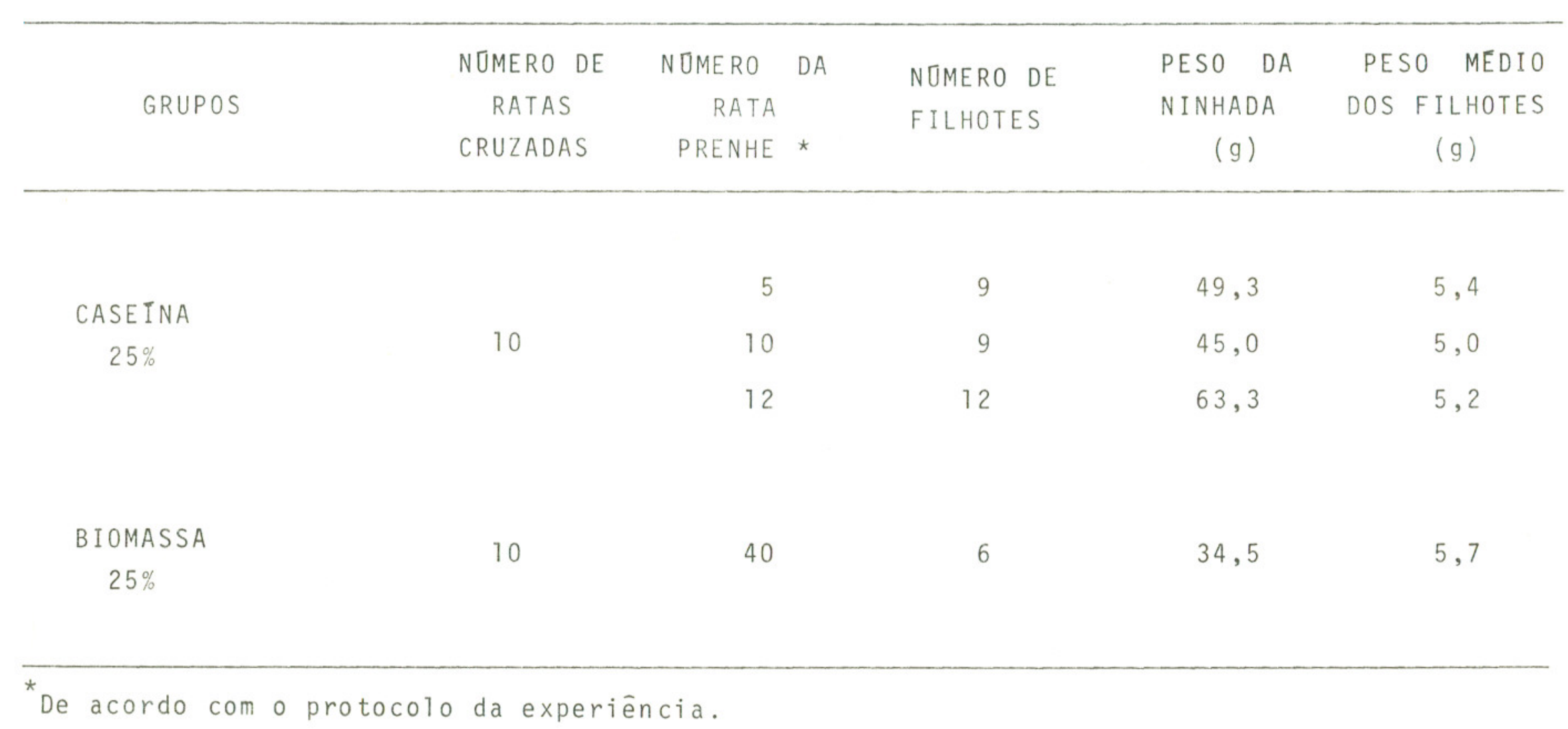


TABELA 17 - Resultados obtidos do cruzamento dos animais da la. geração, alimentados com rações de caseína e biomassa, ao nîvel protéico de 10\%, até a fase adulta. (COZzoLINO, 1982).

\begin{tabular}{|c|c|c|c|c|c|}
\hline GRUPOS & $\begin{array}{l}\text { NUMERO DE } \\
\text { RATAS } \\
\text { CRUZADAS }\end{array}$ & $\begin{array}{l}\text { NOMERO DA } \\
\text { RATA } \\
\text { PRENHE * }\end{array}$ & $\begin{array}{l}\text { NUMERO DE } \\
\text { FILHOTES }\end{array}$ & $\begin{array}{l}\text { PESO DA } \\
\text { NINHADA } \\
(\mathrm{g})\end{array}$ & $\begin{array}{c}\text { PESO MEDIO } \\
\text { DOS FILHOTES } \\
(\mathrm{g})\end{array}$ \\
\hline \multirow{8}{*}{$\begin{array}{c}\text { CASEINA } \\
10 \%\end{array}$} & \multirow{8}{*}{10} & 19 & 13 & 57,5 & 4,4 \\
\hline & & 20 & 9 & 46,8 & 5,2 \\
\hline & & 21 & 10 & 63,3 & 6,3 \\
\hline & & 22 & 7 & 26,5 & 3,7 \\
\hline & & 23 & 9 & 42,0 & 4,6 \\
\hline & & 26 & 6 & 38,5 & 6,4 \\
\hline & & 28 & 7 & 29,3 & 4,1 \\
\hline & & 30 & 11 & 67,0 & 6,0 \\
\hline $\begin{array}{c}\text { BIOMASSA } \\
10 \%\end{array}$ & 10 & - & - & - & - \\
\hline
\end{tabular}

* De acordo com o protocolo da experiência 
surpresa, pois os animais alimentados com rações de biomassa em ambos nïveis protēicos, apresentaram baixo indice de fertilidade, contrariamente aos resultados obtidos por outros autores $(5)$ $(45)(79)(110)$.

Verificamos assim na Tabela 16 , que das 10 ratas que receberam ração de biomassa, ao nỉvel protēico de $25 \%$, apenas 1 deu cria, e quando o nỉvel protēico foi limitado a 10\% na ração (Tabela 17), o resultado foi nulo.

Por outro 1 ado, os animais que receberam ração de caseīna ao nīvel protēico de $25 \%$, tambëm apresentaram baixa fertị lidade, não ocorrendo o mesmo para o grupo de animais alimentados com ração de caseỉna ao nīvel protēico de $10 \%$, que das 10 ratas cruzadas, 8 obtiveram filhotes.

Com estes resultados, não poderīamos prosseguir em nosso experimento, fato que nos levou a tentar um 20 cruzamento, utilizando as fêmeas do experimento que não ficaram prenhes, com ratos machos normais da nossa colōnia, mantidos com ração comer cial para ratos.

Os resultados deste segundo cruzamento, encontram-se nas Tabelas 18 e 19 .

Novamente os resultados nos surpreenderam, pois houve um acentuado aumento do indice de fertilidade para os grupos de fêmeas alimentadas com rações de biomassa, embora ao nîvel protēico de $10 \%$ na ração, houve um alto indice de mortalidade, da ordem de $37 \%$. Talvez este fato possa ser atribuido a um instinto de defesa da mãe, que não podendo suportar uma lacta ção, mata, e muitas vezes, come seus prōprios filhotes. 
TABELA 18 - Resultados do segundo cruzamento das fêmeas da 1a. geração, alimentadas com rações de caseĩna e biomassa, ao nível protéico de $25 \%$, com ratos machos do biotério da Faculdade de Ciências Farmacêuticas - USP, criados com ração comercial. (COZZOLINO, 1982).

\begin{tabular}{|c|c|c|c|c|c|}
\hline GRUPOS & $\begin{array}{l}\text { NUMERO DE } \\
\text { RATAS } \\
\text { CRUZADAS }\end{array}$ & $\begin{array}{l}\text { NUMERO DA } \\
\text { RATA } \\
\text { PRENHE ** }\end{array}$ & $\begin{array}{l}\text { NUMER.O DE } \\
\text { FILHOTES }\end{array}$ & $\begin{array}{l}\text { PESO DA } \\
\text { NINHADA } \\
(\mathrm{S})\end{array}$ & $\begin{array}{c}\text { PESO MEDIO } \\
\text { DOS FILHOTES } \\
(\mathrm{g})\end{array}$ \\
\hline CASEINA & \multirow{2}{*}{$7 *$} & 8 & 12 & 64,2 & 5,3 \\
\hline $25 \%$ & & 1 & 8 & 52,0 & 6,5 \\
\hline BI OMASSA & & 39 & 9 & 43,0 & 4,7 \\
\hline \multirow[t]{3}{*}{$25 \%$} & $9 *$ & 42 & 9 & 52,4 & 5,8 \\
\hline & & 43 & 3 & 14,6 & 4,8 \\
\hline & & 47 & 11 & 67,0 & 6,0 \\
\hline
\end{tabular}

* Ratas que não ficaram prenhes no primeiro cruzamento.

**De acordo com o protocolo da experiēncia 
TABELA 19 - Resultados do segundo cruzamento das fêmeas da la, geração, alimentados com rações de caseĩna e biomassa, ao nīvel protéico de 10\%, com ratos machos do bioté rio da Faculdade de Ciências Farmacêuticas - USP, criados com ração comercial. (COZZOLINO, 1982).

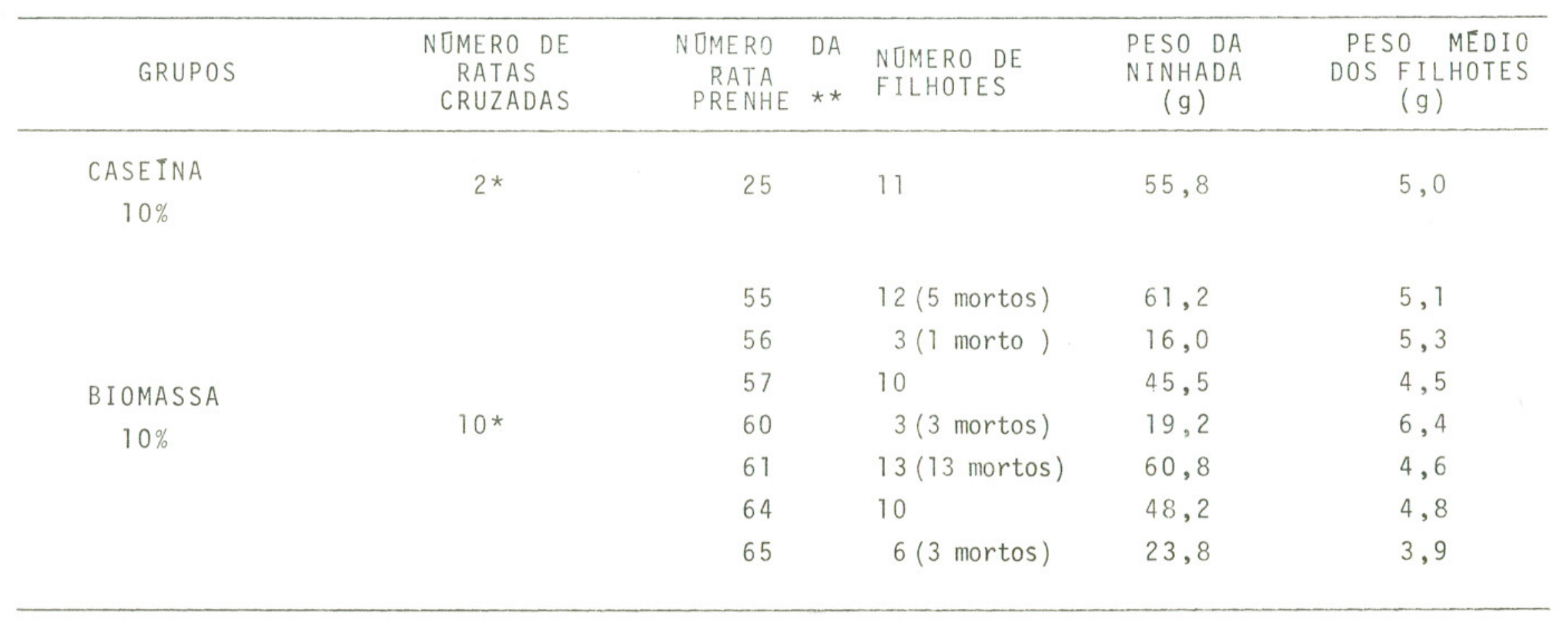

* Ratas que não ficaram prenhes do primeiro cruzamento.

**De acordo com o protocolo da experiēncia 
Outros autores tem tambëm verificado, al tos îndices de mortalidade em animais, decorrentes de estados de desnutri çãol $(9)(26)$.

Destes cruzamentos, verificamos que o peso corporal dos filhotes ao nascer, foi semelhante, não demonstrando alte rações aparentes devidas ao tratamento.

$\mathrm{Na}$ ëpoca do desmame, estes animais novamente foram colocados em gaiolas individuais e alimentados atē a fase adul ta, nas mesmas condições anteriormente descritas, sendo então cruzados para obtenção da $3 a$. geração. Entretanto, como pode-se observar atravës das Tabelas 20 e 21 , o nümero de animais cruzados foi reduzido, devido aos problemas na obtenção da 2a. geração.

Analisando-se portanto estas tabelas, verificamos que novamente o fenômeno se repetiu, os animais alimentados com ra ções de biomassa em ambos os nîveis protēicos, não produziram crias .

Verificamos tambëm que o grupo de fêmeas alimentadas com ração de caseîna, ao nỉvel protēico de $10 \%$, apresentou um indice de fertilidade inferior ao anterior, sem entretanto ser significativo devido ao pequeno nümero de animais. Porēm, este fato ē perfeitamente compreensīvel, uma vez que estes animais sofreram deficiência protēica desde a fase gestacional atē a fase adulta.

Assim, novamente tentamos um segundo cruzamento com ratos machos normais, seguindo o mesmo esquema anterior da 7 . geração. Os resultados deste segundo cruzamento encontram-se 
TABELA 20 - Resultados obtidos do cruzamento dos animais da $2 a$. geração, alimentados com rações de caseĩna e biomassa, ao nīvel protéico de 25\%, atē a fase adulta. (cozzoLINO, 1982).

\begin{tabular}{|c|c|c|c|c|c|c|c|}
\hline GRUPOS & $\begin{array}{l}\text { NUMERO DE } \\
\text { RATAS } \\
\text { CRUZADAS }\end{array}$ & $\begin{array}{l}\text { NOMERO } \\
\text { RATA } \\
\text { PRENHE }\end{array}$ & $\begin{array}{l}\text { DA } \\
\text { * }\end{array}$ & $\begin{array}{l}\text { NÜMERO DE } \\
\text { FILHOTES }\end{array}$ & $\begin{array}{c}\text { PESO DA } \\
\text { NINHADA } \\
(g)\end{array}$ & $\begin{array}{l}\text { PES } \\
\text { DOS }\end{array}$ & $\begin{array}{l}\text { SO MEDIO } \\
\text { FILHOTES } \\
\text { (g) }\end{array}$ \\
\hline & & 1 & & 3 & 18,0 & & 6,0 \\
\hline CASEINA & $\Lambda$ & 2 & & 10 & 55,0 & & 5,5 \\
\hline \multirow[t]{2}{*}{$25 \%$} & 4 & 3 & & 9 & 46,0 & & 5,1 \\
\hline & & 4 & & 6 & 33,7 & & 5,6 \\
\hline $\begin{array}{c}\text { B I OMASSA } \\
25 \%\end{array}$ & 4 & - & & - & - & & - \\
\hline
\end{tabular}

*De acordo com o protocolo da experiência 
TABELA 21 - Resultados obtidos do cruzamento dos animais da 2 a. geração, alimentados com rações de caseĩna e biomassa, ao nīvel protéico de 10\%, até a fase adulta. (cozzoLINO, 1982)

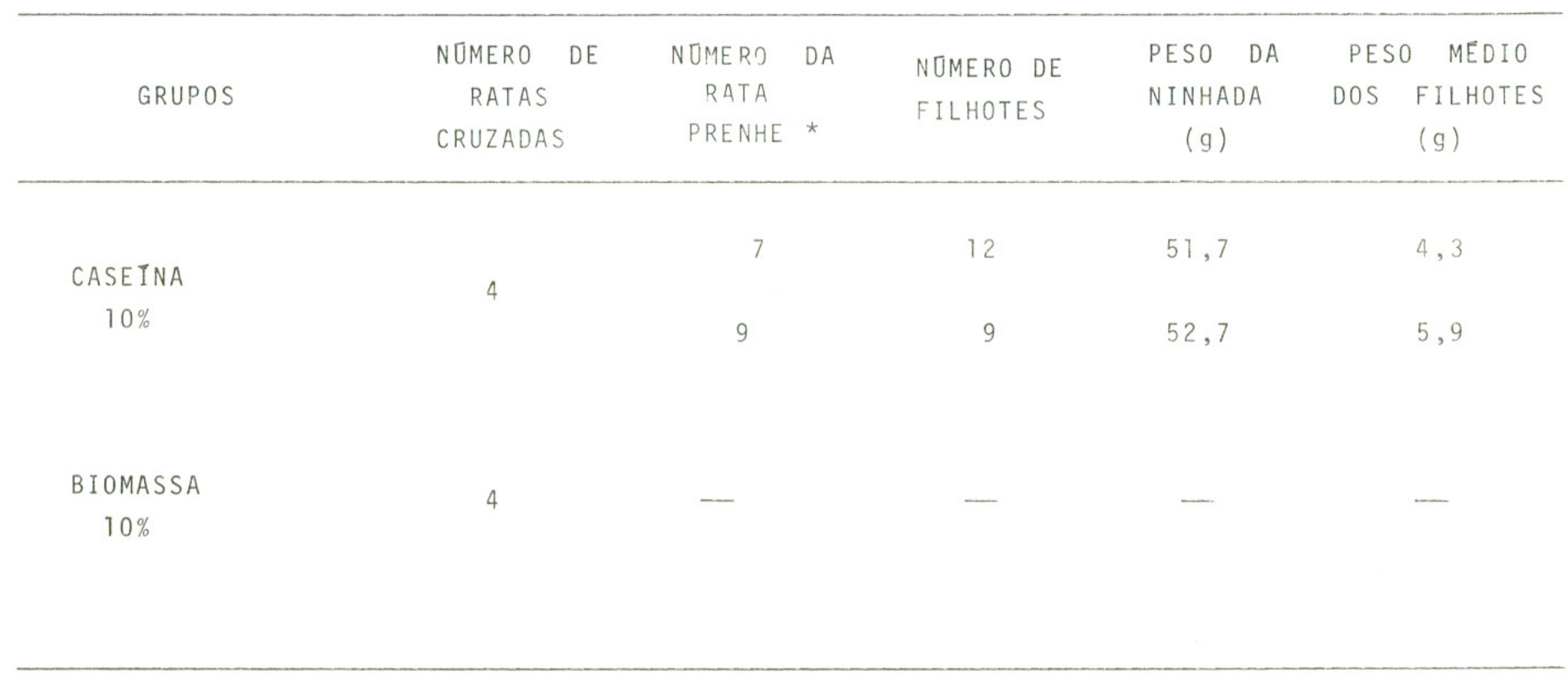

*De acordo com o protocolo da experiência 
nas Tabelas 22 e 23. Como podemos observar, o fato se repetiu, entretanto, não foi possỉvel a obtenção da $3 a$. geração de animais alimentados com ração de biomassa ao nível protēico de $10 \%$, ressaltando novamente a importäncia do teor protēico da ração.

Com estes resultados, imaginamos que algum fator pre sente na biomassa, poderia estar interferindo na reprodutibil $\underline{i}$ dade dos animais machos submetidos a este tratamento. Assim, realizamos mais 3 experimentos paralelos, que não constam deste trabalho, para tentar descobrir a que nivel este fato pode ria estar ocorrendo. Em um deles, selecionamos 6 animais machos de nossa colónia e novamente os alimentamos com ração de biomassa ao nīvel protēico de $25 \%$, atē a fase adulta, cruzan do-os com ratas normais do nosso biotērio e novamente não obti vemos crias. Num segundo experimento, tambēm com animais machos normais alimentados atē a fase adulta com ração de biomas sa, foram realizados cortes histolögicos dos testículos, suge rindo-se uma imaturidade a nível de formação de espermatozōi des, entretanto sem poder ser comprovada. Finalmente, em outro experimento seguindo o mesmo esquema anterior, com anāijses mais detalhadas, realizadas no Instituto de Cièncias Biomēdicas da USP*, não observamos anormalidades de testículo.

Nossos resultados estão em desacordo com a maioria dos autores que trabalharam com gerações de animais alimenta-

*Agradecemos a Dra. Lor Cury, pela especial atenção, ao reali zar estas anālises. 
TABELA 22 - Resultados do segundo cruzamento das fêmeas da 2a. geração, alimentadas com rações de caseína e biomassa, ao nĩvel protéico de $25 \%$, com ratos machos do biotério da Faculdade de Ciēncias Farmacêuticas da USP, criados com ração comercial. (COZZOLINO, 1982).

\begin{tabular}{|c|c|c|c|c|c|c|}
\hline \multirow[b]{2}{*}{ GRUPOS } & NUMERO DE & NUMERO DA & NUMERO DE & \multirow{2}{*}{$\begin{array}{l}\text { PESO DA } \\
\text { NINHADA } \\
(\mathrm{g})\end{array}$} & \multirow{2}{*}{\multicolumn{2}{|c|}{$\begin{array}{c}\text { PESO MEDIO } \\
\text { DOS FILHOTES } \\
(\mathrm{g})\end{array}$}} \\
\hline & $\begin{array}{c}\text { RATAS } \\
\text { CRUZA.DAS }\end{array}$ & $\begin{array}{c}\text { RATA } \\
\text { PRENHE** }\end{array}$ & FILHOTES & & & \\
\hline \multirow[t]{2}{*}{$\begin{array}{c}\text { CASEINA } \\
25 \%\end{array}$} & - & - & - & - & \multicolumn{2}{|r|}{-} \\
\hline & \multirow{4}{*}{$4 *$} & 13 & 9 & 52,9 & & 5,9 \\
\hline BIOMASSA & & 14 & 6 & 27,0 & & 4,5 \\
\hline $25 \%$ & & 15 & 12 & 63,8 & & 5,3 \\
\hline & & 16 & 13 & 64,1 & & 4,9 \\
\hline
\end{tabular}

* Ratas que não ficaram prenhes no primeiro cruzamento

** De acordo com o protocolo da experiēncia 
TABELA 23 - Resultados do segundo cruzamento das fêmeas da 2 a. geração alimentadas com rações de caseĩna e biomassa, ao nīvel protéico de 10\%, com ratos do biotério da Faculdade de Ciências Farmacêuticas - USP, criados com ração comercial. (CozzoLINO, 1982).

\begin{tabular}{ccccccc}
\hline GUMERO & DE & NUMERO & DA & NUMERO DE & PESO DA & PESO MEDIO \\
GRUPOS & RATAS & RATA & FILHOTES & NINHADA & DOS FILHOTES \\
& CRUZADAS & PRENHE** & & $(\mathrm{g})$ & $(\mathrm{g})$
\end{tabular}

$\begin{aligned} & \text { CASEINA } \\ & 10 \% \\ & \text { BIOMASSA } \\ & 10 \%\end{aligned}$
$\begin{aligned} & \text { * } \\ & \text { Ratas que não ficaram prenhes no primeiro cruzamento. }\end{aligned}$
De acordo com o protocolo da experiẽncia


dos com fonte protëica de leveduras.

o ūnico caso em que se observou alterações na reprodução dos animais alimentados com esta fonte protëica, constatou-se ser devida à deficiēncia de vitamina E nas rações, que foram preparadas somente à base de proteỉnas de leveduras sem suplementação de vitaminas, o que não foi o nosso caso.

\subsection{2 - Resultados do valor biolögico da proteina da biomassa em estudos de gerações}

As mesmas considerações descritas no ensaio biolōgi co de curta duração, podem ser levantadas novamente, uma vez que repetimos os mesmos parāmetros anteriormente estudados, ne $\underline{s}$ te ensaio de longa duração, com gerações de animais.

Entretanto, procuramos analisā-los de forma global, evidenciando quando necessārio as diferenças relativas às 3 ge rações, observadas dentro do mesmo grupo, como tambēm entre os diferentes grupos.

Assim, nas Tabelas 24 e 25 e Figuras de 1 a 4 apresen tamos os resultados obtidos em relação ao peso corporal dos animais, submetidos aos diferentes tratamentos.

Analisando-se estas tabelas, verificamos que os grupos de animais alimentados com rações controle de caseĩna, mos traram-se em todos os casos analisados, superiores aos grupos de animais alimentados com rações de biomassa. 
TABELA 24 - Mëdias e desvio padrão do peso corporal (g), de 3 gerações de animais, alimen tados com ração controle de caseina e experimental de biomassa, ao nível protéico de $25 \%$, nos diferentes períodos da experiência. (COZZOLINo, 1982).

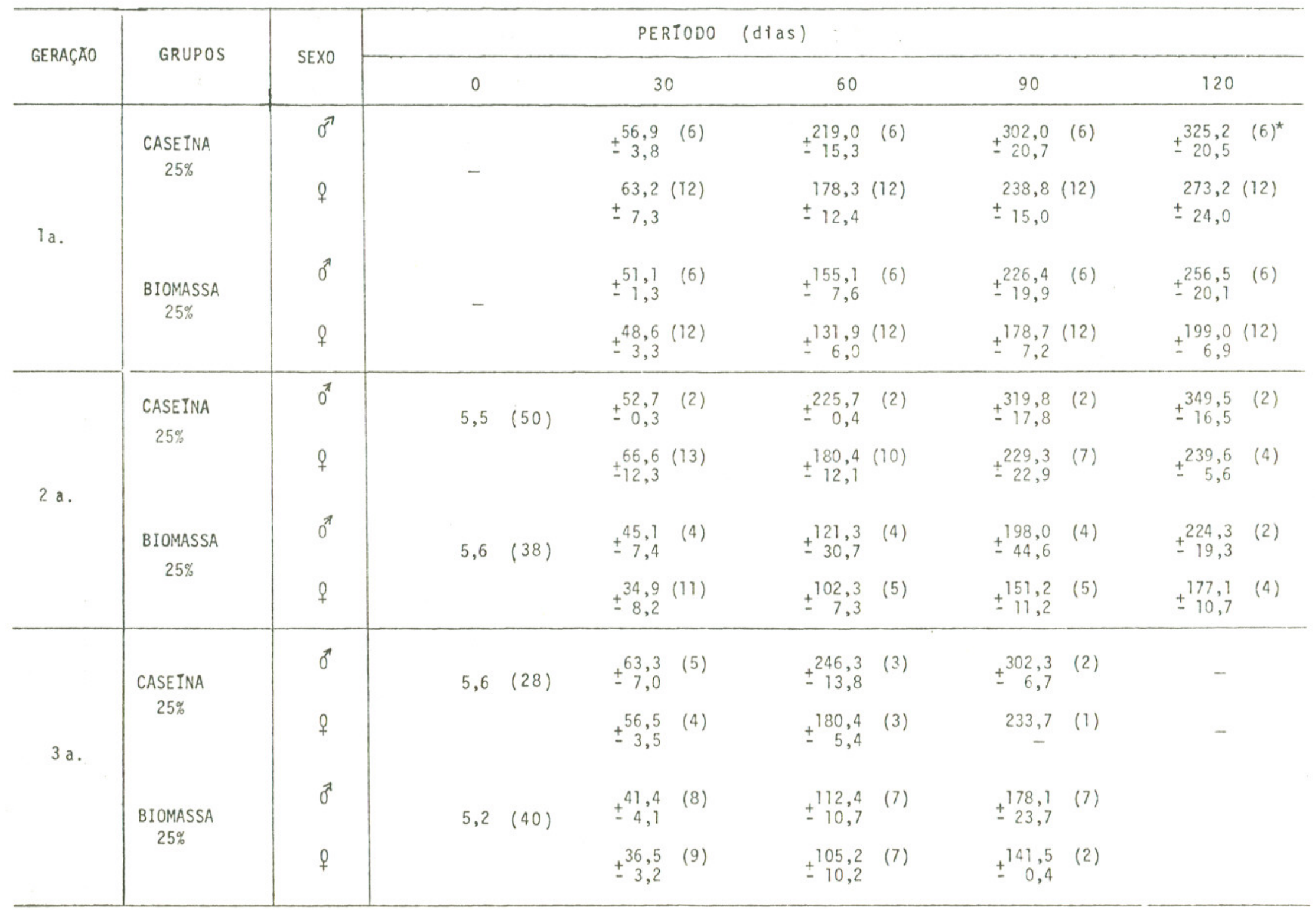

"Entre parenteses o nümero de animais. 
TABELA 25 - Mëdias e desyio padrão do peso corporal (g), de 3 gerações de animais, alimen tados com ração controle de caseîna e experimental de biomassa, ao nĩvel pro= tëico de $10 \%$, nos diferentes períodos da experiência. (COZZOLINo, 1982).

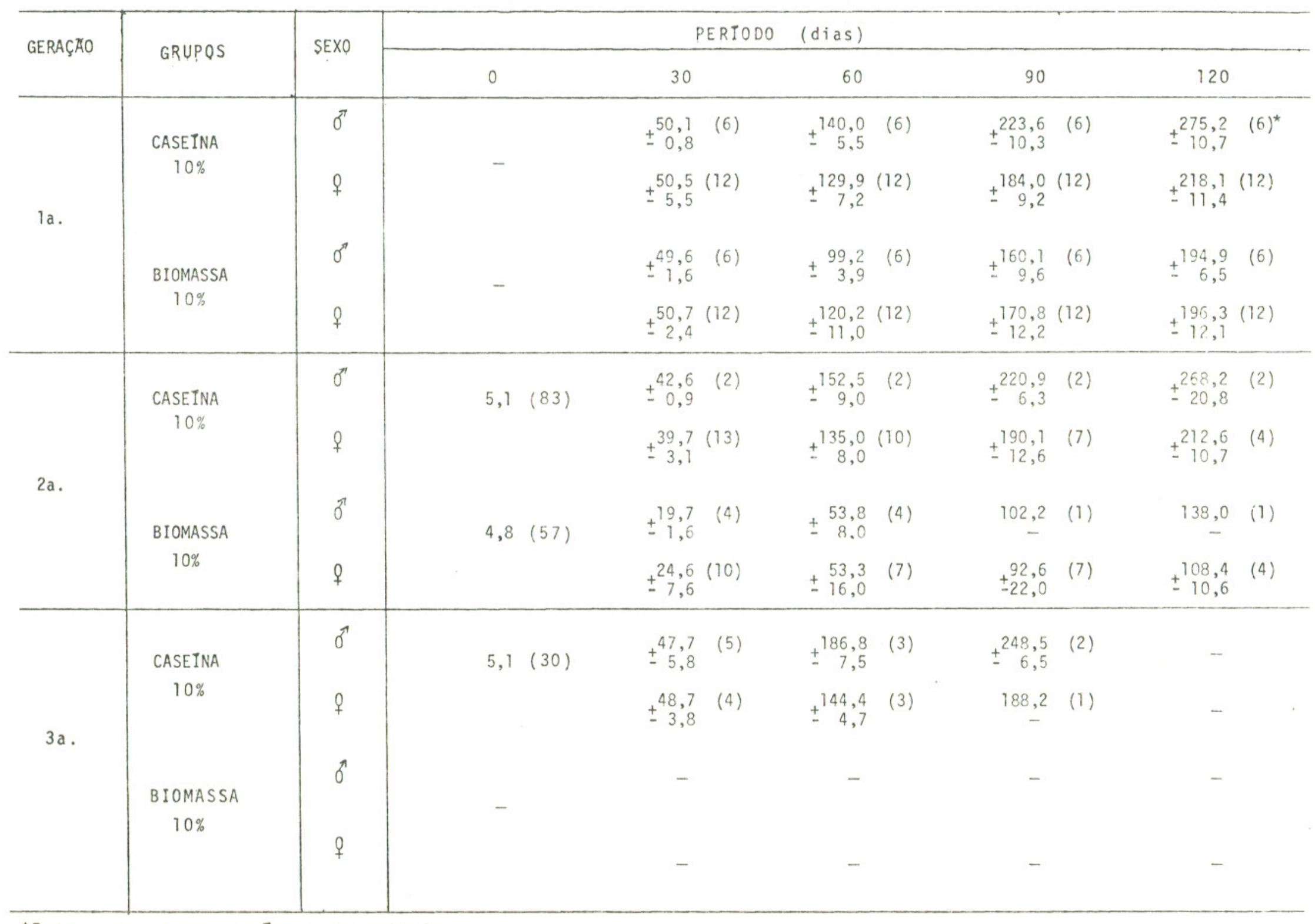


As diferenças em relação ao peso corporal dos animais aos 30 dias de idade, no inīcio da primeira geração, demonstraram a influência da ração da mãe no período de lactação, em relação ao desenvolvimento dos filhotes.

Assim, verificamos que os filhotes recem desmamados, de ratas alimentadas com ração de caseîna ao nīvel protēico de $25 \%$ apresentaram peso corporal superior ao dos demais grupos, mostrando a importância da qualidade e quantidade de proteīna na ração neste perĩodo.

Apōs 4 semanas iniciais da primeira geração, avaliamos novamente os pesos corporais dos animais e verificamos que houve diferenças de comportamento entre os värios grupos estudados. A anälise estatistica destes resultados, encontram-se na Tabela 26 .

A anālise desta tabela demonstra que houve diferença significativa ao nīvel de $0,1 \%$, entre os grupos de animais alimentados com ração de caseína ao nīvel protēico de $25 \%$ em rela ção ao sexo, o mesmo podendo-se dizer em relação aos grupos de animais alimentados com ração de biomassa ao nível protēico de $25 \%$. Este fato ē perfeitamente compreensīvel, pois sabe-se da fisiologia, que normalmente os machos crescem mais do que as fêmeas.

Em relação aos grupos de animais alimentados com rações de caseỉna ao nīvel protēico de $10 \%$, observamos tambēm dị ferença significativa em relação ao sexo, porëm ao nîvel de $5 \%$. Neste caso, dada a menor disponibilidade protëica, esta diferença não mostrou-se tão acentuada como no grupo anterior. 
TABELA 26 - Resultados da anālise de variāncia multivariada para o peso corporal da la. geração de animais, do desmame até 30 dias, alimentados com rações de caseina e biomassa, aos niveis proteícos de $25 \%$ e $10 \%$. (COZZOLINO, 1982).

\begin{tabular}{|c|c|c|c|c|c|}
\hline COMPARAÇOES & & $\mathrm{F}$ & GL & $\mathrm{p}$ & CONCLUSOES \\
\hline Caseĩna $25 \%$ o $\times$ Caseina & $25 \% \sigma$ & 64.8862 & 1,62 & 0,0001 & $\star \star \star *$ \\
\hline Biomassa $25 \% q \times$ Biomassa & $25 \% \sigma^{\prime}$ & 21.4733 & 1,62 & 0,0001 & $\star \star \star$ \\
\hline Caseỉna $10 \%$ o $x$ Caseina & $10 \% \sigma^{7}$ & 6.1333 & 1,62 & 0,0152 & * \\
\hline Biomassa $10 \% q \times$ Biomassa & $10 \% \sigma^{\pi}$ & 1.0908 & 1,62 & 0,3008 & N.S. \\
\hline Caseĩna $25 \% q \times$ Biomassa & $25 \% q$ & 122.2476 & 1,62 & 0,0001 & $* \star \star$ \\
\hline Caseina $25 \% \sigma \times$ Biomassa & $25 \% \sigma^{7}$ & 120.6301 & 1,62 & 0,0001 & $\star * *$ \\
\hline Caseĩna $10 \% q \times$ Biomassa & $10 \%$ q & 11.4889 & 1,62 & 0,0016 & $\star \star$ \\
\hline Caseina $10 \% \sigma^{7} \times$ Biomassa & $10 \% \sigma^{*}$ & 25.0838 & 1,62 & 0,0001 & $\star \star \star *$ \\
\hline $\begin{array}{l}\text { (Caseina 25\% } 0 \times \text { Biomassa } \\
\text { (Caseina } 10 \% \text { 年 } \times \text { Biomassa }\end{array}$ & $\begin{array}{l}25 \% \text { f) } \\
10 \% \text { f) }\end{array}$ & 32.5191 & 1,62 & 0,0001 & 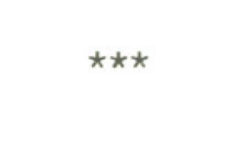 \\
\hline $\begin{array}{l}\text { (Caseina } 25 \% \quad \sigma^{7} \times \text { Biomassa } \\
\text { (Caseĩna } 10 \% \quad \sigma^{\pi} \times \text { Biomassa }\end{array}$ & 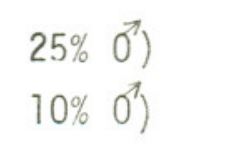 & 17.0012 & 1,62 & 0,0003 & $\star \star \star$ \\
\hline$* * * \quad$ - significativa & ao nível & de $0,1 \%$ & & & \\
\hline ** - significativa & ao nīvel & de $1 \%$ & & & \\
\hline * - significativa & ao nīvel & de $5 \%$ & & & \\
\hline
\end{tabular}


Quanto aos grupos de animais alimentados com ração de biomassa ao nîvel protēico de $10 \%$, os resultados não apre sentaram diferenças significativas, confirmando uma vez mais o que jā dissemos anteriormente em relação à qualidade e quantidade protēica de ração.

Por outro lado, comparando-se os grupos de animais con trole e experimentais alimentados com rações ao nīvel protēico de $25 \%$, verificamos que os grupos de caseĩna, tanto machos como fêmeas mostraram-se superiores aos de biomassa, ao nīvel de $0,1 \%$ de significância. Em relação aos grupos de animais con trole e experimentais ao nível protēico de $10 \%$, observamos que quando a comparação foi realizada com animais machos, a dife rença foi significativa ao nível de $0,1 \%$, entretanto, quando a comparação foi com as fēmeas, verificamos que a diferença foi significativa ao nîvel de $1 \%$. Tal fato pode ser explicado, uma vez que os animais machos, alimentados com uma racão cuja fonte proteíca foi de qualidade superior, puderam obter maior aproveitamento da ração que influenciou em sua capacidade de sīntese protēica, consequentemente em relação ao seu desenvolvimento fisiológico, fato que não ocorreu com os animais ali mentados com ração de biomassa ao nīvel protëico de $10 \%$, que não tiveram condições de desenvolver esta capacidade, comportando-se portanto de forma semelhante às fêmeas do mesmo grupo, motivo pelo qual, a comparação entre os grupos de fêmeas alimentadas com rações de caseĩna e biomassa apresentaram-se diferentes a um menor nīvel de significância.

Quando a comparação foi realizada para se verificar 
a influência do teor protēico nas diferenças entre os grupos submetidos aos dois tratamentos, verificamos que houve diferen ça significativa ao nîvel de $0,1 \%$, tanto para machos como para fēmeas.

Aos 90 dias de vida, o peso corporal dos animais foi novamente analisado, e verificamos atravës da Tabela 27, que novamente os grupos iniciais de animais alimentados com caseĩna e biomassa, ao nīvel protēico de $25 \%$, comportaram-se da me $\underline{s}$ ma forma anterior em relação ao sexo. portanto os animais machos continuaram apresentando um desenvolvimento superior ao das fêmeas, com diferenças significativas em relação ao peso corporal ao nīvel de $0,1 \%$.

Entretanto, em relação aos grupos de animais submeti dos às rações de caseīna e biomassa ao nīvel protēico de $10 \%$, obtivemos um comportamento diferente para os grupos de animais alimentados com caseỉna, que aumentaram as diferenças anterior mente observadas entre animais machos e fêmeas, para o nīvel significativo de $0,1 \%$. Não verificamos tal fato em relação aos grupos de animais alimentados com biomassa.

A comparação entre os grupos de animais alimentados com rações de caseĩna e biomassa, ao nîvel protểco de $25 \%$, novamente aos 90 dias de vida do animal, apresentou diferença significativa de peso corporal ao nivel de $0,1 \%$, estes dados referem-se à comparação realizada entre machos e entre fêmeas. Por outro lado, quando a comparação foi realizada en tre os grupos de animais alimentados com rações de caseĩna e biomassa ao nīvel protēico de $10 \%$, verificamos novamente o ca- 
TABELA 27 - Resultados da anālise de variância multivariada para o peso corporal da la. geração de animais, do desmame até 60 dias, alimentados com rações de caseĩna e biomassa, aos níveis protéicos de $25 \%$ e $10 \%$. (COZZOLINO, 1982).

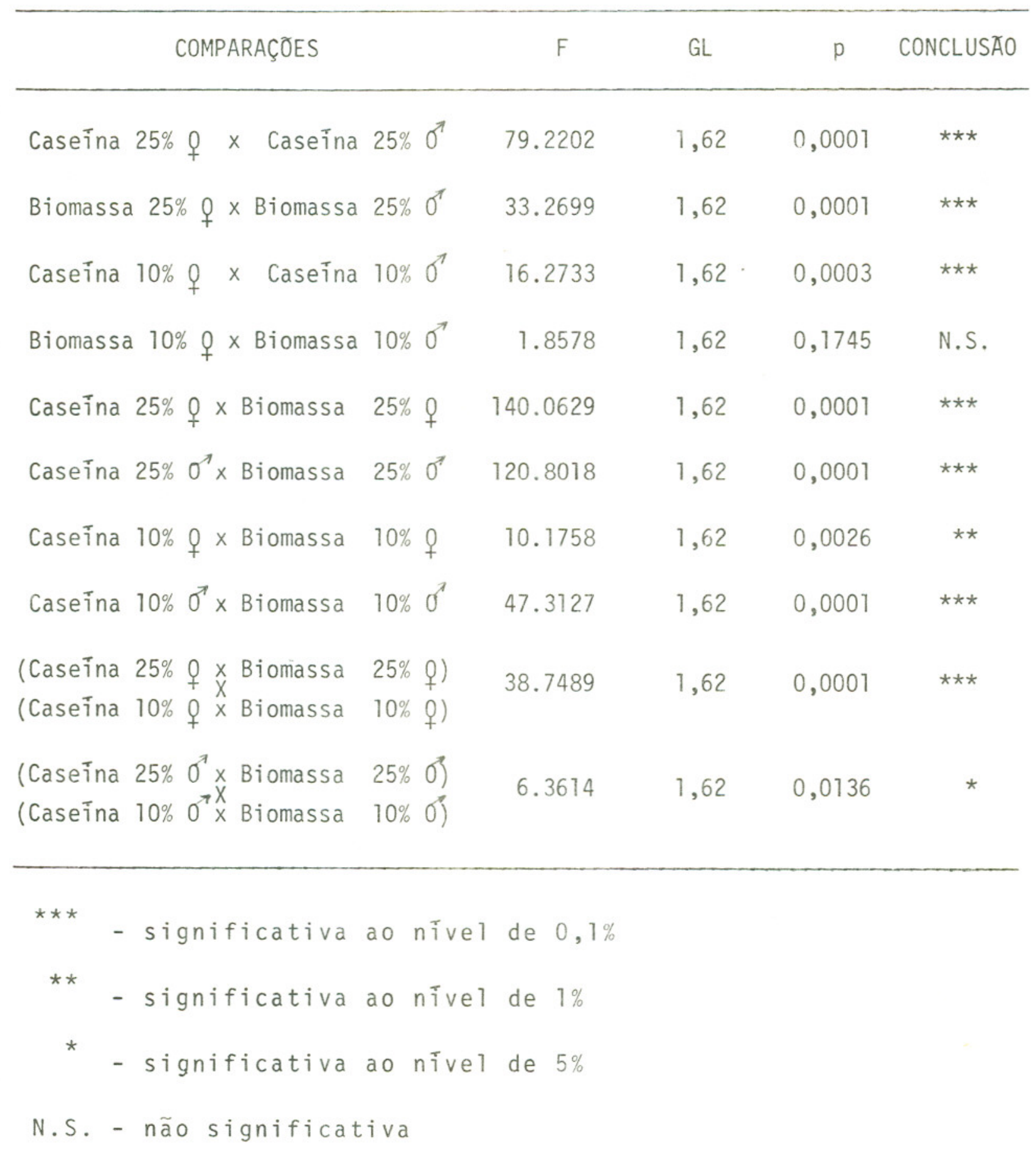


so anterior, com os grupos de animais machos apresentando dife renças significativas ao nïvel de $0,1 \%$ e as fêmeas ao nîvel de $1 \%$. Convēm ressaltarmos neste caso, como jā discutimos desde - inicio deste trabalho, que os grupos de animais alimentados com ração da biomassa, embora apresentando um teor de nitrogênio na ração semelhante ao da ração de caseĩna, parte deste ni trogênio ē de origem não proteīca, que não sendo totalmente a sorvida pelo organismo, interferem no processo de digestibili dade, confirmando uma vez mais o menor valor biolögico desta proteîna quando comparada à de caseỉna.

Em relação à influēncia do teor protēico entre as di ferenças observadas entre os grupos controle e experimentais, verificamos que neste caso, o grupo de fēmeas apresentaram diferença significativa ao nīvel de $0,1 \%$, e em relação aos machos, esta diferença foi significativa ao nĩvel de $5 \%$.

Estes ültimos resultados novamente confirmam as diferenças observadas em relação ao comportamento fisiolōgico dos animais machos e fêmeas.

$\mathrm{Na}$ fase adulta dos animais, com 120 dias, esta mesma anāilise (Tabela 28) demonstrou que as tendências anteriores fo ram mantidas, que os grupos de animais alimentados com ração contendo biomassa ao nîvel protëico de 10\%, comportaram-se de forma semelhante em relação ao sexo, que a comparação entre os grupos de animais fêmeas alimentadas com ração de caseína e biomassa ao nīvel protëico de $10 \%$, aumentaram a diferença entre eles para o nĩvel de $0,1 \%$ e as comparações relativas aos teores protëicos, indicaram que as diferenças entre os grupos 
TABELA 28 - Resultados da anālise de variância multivariada para o peso corporal da la. geração de animais, do des mame até 90 dias, alimentados com rações de caseína e biomassa, aos níveis protéicos de $25 \%$ e $10 \%$. (COzZOLINO, 1982).

GL

p CONCLUSAO

\begin{tabular}{|c|c|c|c|c|c|c|c|}
\hline Caseina & $25 \% q \times$ & x Caseîna & $25 \% \sigma^{7}$ & 58.6671 & 1,62 & 0,0001 & $* * *$ \\
\hline Biomassa & a $25 \% \underset{t}{0} \times$ & x Biomassa & $25 \% 0^{\pi}$ & 25.0303 & 1,62 & 0,0001 & $\star \star *$ \\
\hline Caseĩna & $10 \% q x$ & x Caseina & $10 \% \sigma^{7}$ & 28.0076 & 1,62 & 0,0001 & $* \star \star$ \\
\hline Biomassa & a $10 \% \underset{t}{0} \times$ & x Biomassa & $10 \% \sigma$ & 0.7518 & 1,62 & 0,6066 & N.S. \\
\hline Caseĩna & $25 \% \underset{q}{0} \times$ & Biomassa & $25 \% ?$ & 97.4787 & 1,62 & 0,0001 & 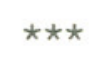 \\
\hline Caseîna & $25 \% \sigma^{7} x$ & Biomassa & $25 \% \sigma^{7}$ & 79.0605 & 1,62 & 0,0001 & $\star \star \star$ \\
\hline Caseĩna & $10 \% \underset{x}{ }$ & Biomassa & $10 \% \underset{+}{0}$ & 13.2228 & 1,62 & 0,0009 & $\star \star \star \star$ \\
\hline Caseỉna & $10 \% \sigma_{x}$ & Biomassa & $10 \% 0^{\prime \prime}$ & 66.4377 & 1,62 & 0,0001 & $\star \star \star \star$ \\
\hline $\begin{array}{l}\text { (Caseĩna } \\
\text { (Caseĩna }\end{array}$ & $\begin{array}{lll}25 \% & 0 & x \\
10 \% & 0 & x \\
& x\end{array}$ & $\begin{array}{l}\text { Biomassa } \\
\text { Biomassa }\end{array}$ & $\begin{array}{l}25 \% \text { f) } \\
10 \% \\
\text { f) }\end{array}$ & 23.4193 & 1,62 & 0,0001 & 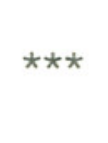 \\
\hline $\begin{array}{l}\text { (Caseĩna } \\
\text { (Caseĩna }\end{array}$ & $\begin{array}{l}25 \% \sigma^{7} x \\
10 \% \sigma_{x}^{x} x\end{array}$ & $\begin{array}{l}\text { Biomassa } \\
\text { Biomassa }\end{array}$ & $\begin{array}{l}25 \% \text { O } \\
10 \% \text { O) }\end{array}$ & 0.4244 & 1,62 & 0,5242 & N.S. \\
\hline
\end{tabular}

\footnotetext{
*** - significativa ao nivel de $0,1 \%$

** - significativa ao nivel de $1 \%$

* - significativa ao nível de $5 \%$

N.S. - não significativa
} 
de animais machos alimentados com ração de caseĩna e biomassa ao nivvel protēico de $25 \%$, com as diferenças entre os grupos de animais machos alimentados com rações de caseína e biomassa ao nỉvel de $10 \%$, não foram significativas aos 120 dias de vida dos animais, indicando que para estes grupos as diferenças observa das em relação à qualidade protēica da ração se manteve nos dois nỉveis protēicos testados.

Em relação à segunda geração, a anāilise estatística foi realizada apenas com os grupos de fêmeas, pois o nümero de machos foi muito reduzido.

Estas anālises encontram-se nas Tabelas 29,30 e 31 , para os 60,90 e 120 dias respectivamente.

Verificamos, portanto, na Tabela 29 , que os grupos de animais fêmeas alimentadas com rações de caseĩna e biomassa ao nĩvel protēico de $25 \%$, comportaram-se diferentemente em rela ção ao peso corporal ao nível de $0,1 \%$, o mesmo podendo-se dizer dos mesmos grupos ao nível protēico de 10\%. Quando a comparação foì realizada a fim de se verificar a influência do ní vel protēico em relação às diferenças entre os grupos, verificamos que estas não foram significativas. Aos 90 dias de vida dos animais da 2 a. geração (Tabela 30), verificamos a mesma tendência anterior, enquanto aos 120 dias, embora as diferenças persistissem, foram em menor grau, indicando uma adapta ção orgānica do animal ao tipo de alimentação submetida, no sentido de manter seu desenvolvimento no mesmo ritmo atē a fase adulta, diminuindo consequentemente as diferenças observadas na fase adulta. 
TABELA 29 - Resultados da anālise de variāncia multivariada para o peso corporal da 2 a. geração de animais, do desmame atê 30 dias, alimentados com rações de caseĩna e biomassa, aos níveis protéicos de $25 \%$ e $10 \%$. (COZZOLINO, 1982).

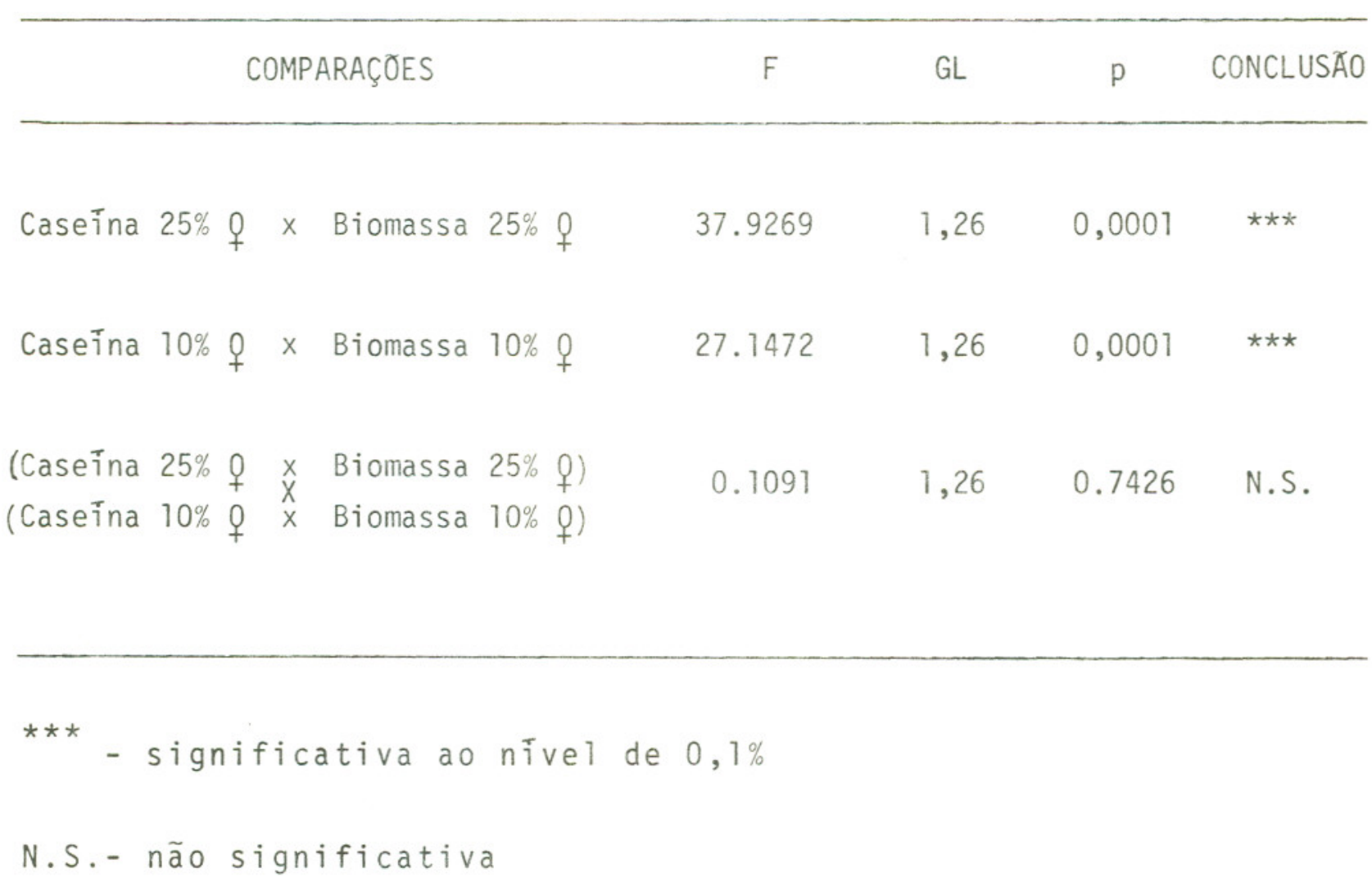


TABELA 30 - Resultados da anālise de variância multivariada pa ra o peso corporal da 2 a. geração de animais, do desmame atē 60 dias, alimentados com rações de caseĩna e biomassa, aos níveis protéicos de $25 \%$ e 10\%. (COZZOLINO, 1982).

\begin{tabular}{|c|c|c|c|c|c|c|c|}
\hline \multicolumn{4}{|c|}{ COMPARAÇбES } & $\mathrm{F}$ & $\mathrm{GL}$ & $p$ & CONCLUSĀO \\
\hline Caseĩna & $25 \%$ & $x$ & Biomassa $25 \%$ & 19.8035 & 1,20 & 0,0004 & $\star \star \star$ \\
\hline Caseĩna & $10 \% q$ & $x$ & Biomassa $10 \% q$ & 39.7566 & 1,20 & 0,0001 & $\star \star \star$ \\
\hline $\begin{array}{l}\text { (Caseina } \\
\text { (Caseina }\end{array}$ & $\begin{array}{ll}25 \% & 0 \\
10 \% & 0\end{array}$ & $\begin{array}{l}x \\
x \\
x\end{array}$ & $\begin{array}{lll}\text { Biomassa } & 25 \% & 0 \\
& & + \\
\text { Biomassa } & 10 \% & 0 \\
\text { B }\end{array}$ & 2.9806 & 1,20 & 0,0964 & N.S. \\
\hline
\end{tabular}

$\star \star * \quad$ - significativa ao nível de $0,1 \%$

N.S. - não significativa 
TABELA 31 - Resultados da anālise de variāncia multivariada para o peso corporal da 2 a. geração de animais, do des mame até 90 dias, alimentados com rações de caseína e biomassa, aos níveis protéicos de $25 \%$ e $10 \%$. (COZZOLINO, 1982).

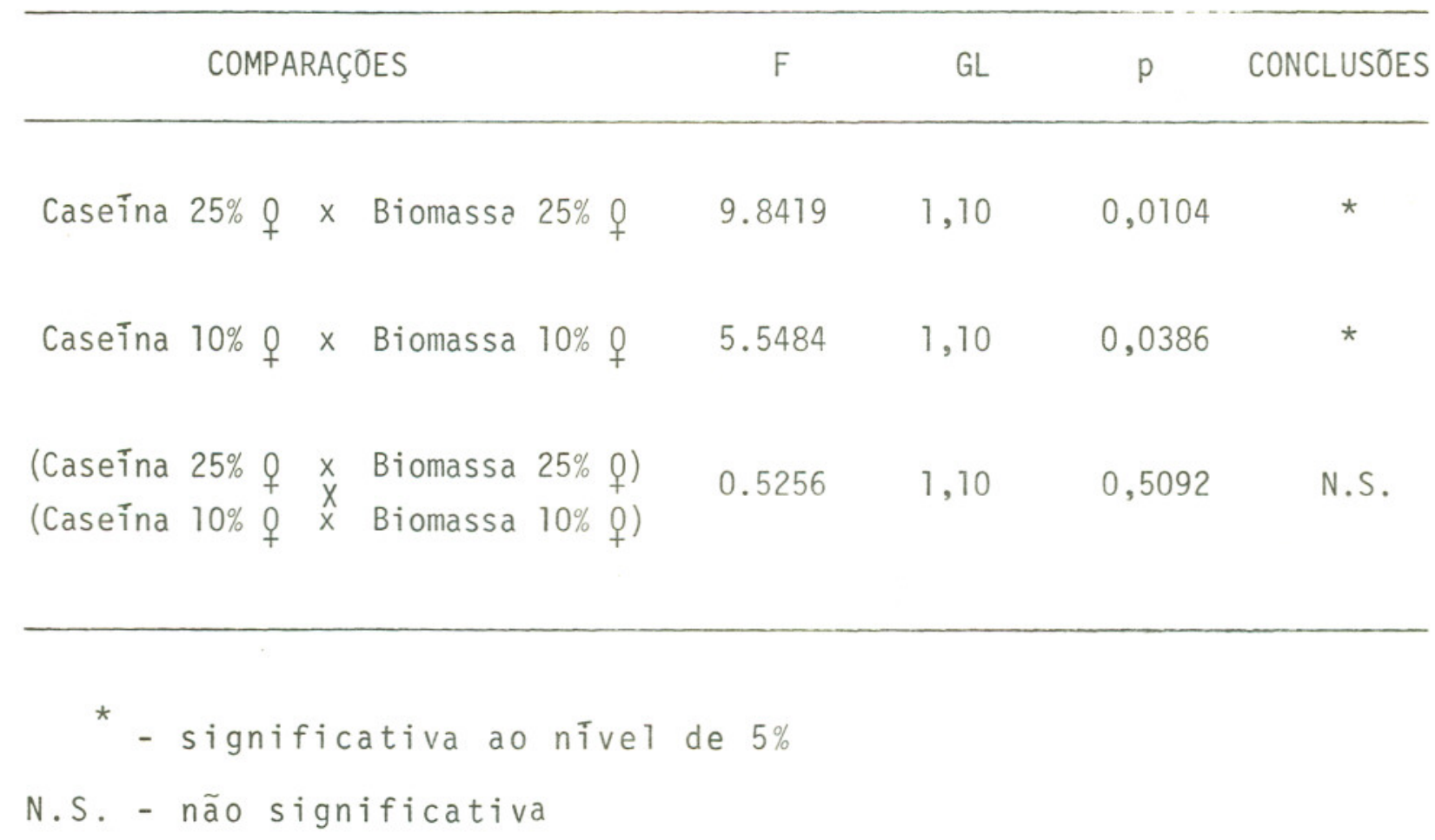


A aplicação da anālise estatistica para os resulta dos obtidos na 3a. geração não foi possīvel de ser reaíizada, devido ao nūmero reduzido de animais, entretanto, a anālise descritiva dos dados, mostrou a mesma tendēncia anteriormente observada para as 1as. e 2as. gerações de animais.

Para melhor visualização do comportamento em relação ao peso corporal dos animais, no desenvolver das 3 gerações, apresentamos nas Figuras de 1 a 4 , as curvas de crescimento ob tidas durante o periodo experimental.

Podemos observar que os grupos de animais alimenta dos com ração de caseĩna apresentaram comportamento semelhante nas 3 gerações, para ambos os nĩveis protēicos. Tal fato não verificou-se para os grupos de biomassa, que mostraram um declīnio da $2 a$. e 3a. geração em relação à 1a. geração, para os dois nīveis protēicos, não sendo possīvel inclusive, a conti nuidade do ensaio para o grupo alimentado com ração de biomassa ao nĩvel protēico de $10 \%$.

Decorrente do peso corporal, os resultados obtidos pa ra ganho de peso dos animais nos diferentes períodos do experi mento, encontram-se nas Tabelas 32 e 33 e nas Figuras de 5 a 10, mostrando o comportamento dos animais nas 3 gerações.

Podemos observar que o ganho de peso sempre foi supe rior para os animais alimentados com caseina, tanto para o nível de $25 \%$ como para o nỉvel de $10 \%$ na ração. Verificamos tam bëm, conforme jā era esperado, que o crescimento maior ocor reu na fase aguda de crescimento atē por volta dos 60 dias de vida, para os grupos de caseĩna, não podendo-se dizer o mesmo 

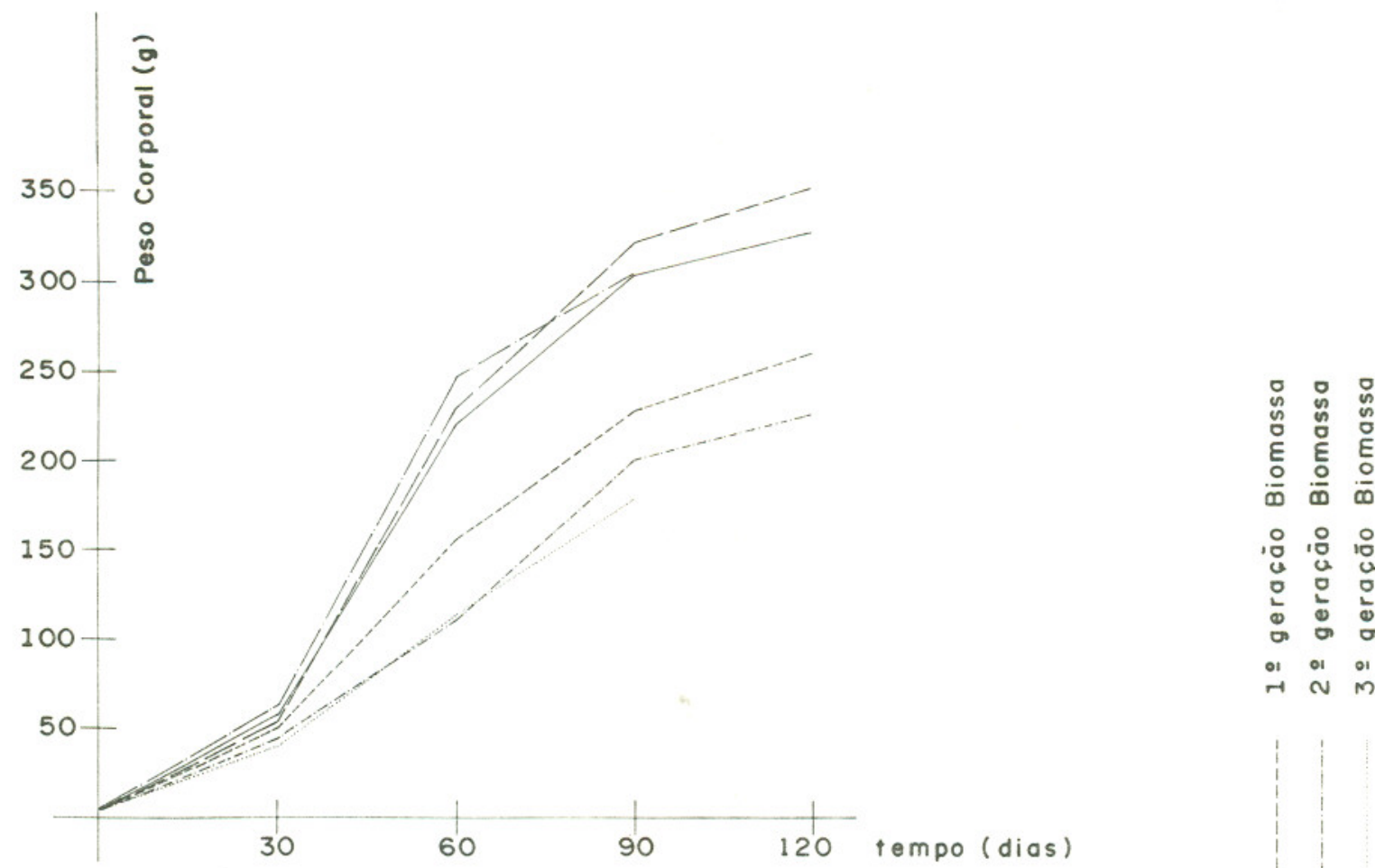

Fig.1-Curva de crescimento, de 3 geracöes de ratos machos, alimentados com raçōes de Caseína e Biomassa. ( $25 \%$ de proteína)

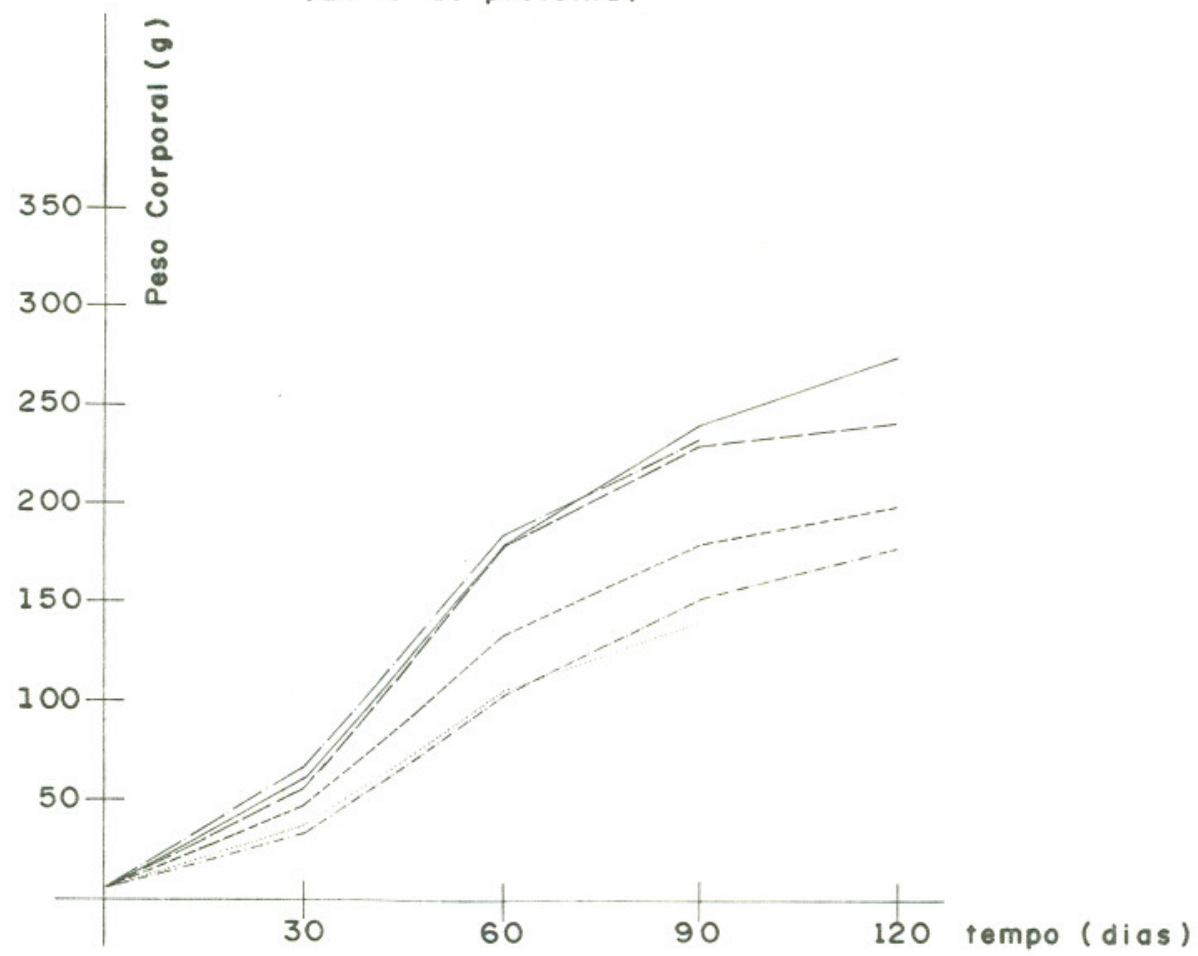

$\begin{array}{lll}0 & 0 & 0 \\ & 0 & 0 \\ 0 & 0 & 0 \\ 0 & 0 & 0 \\ 0 & 0 & 0 \\ 0 & 0 & 0\end{array}$

웅요 임

인 인

๘)

$\stackrel{21}{2} \stackrel{01}{m}$

Fig.2-Curva de crescimento, de 3 geraçōes de ratos fêmeas, alimentados com raçōes de Caseína e Biomassa. ( $25 \%$ de proteína) 


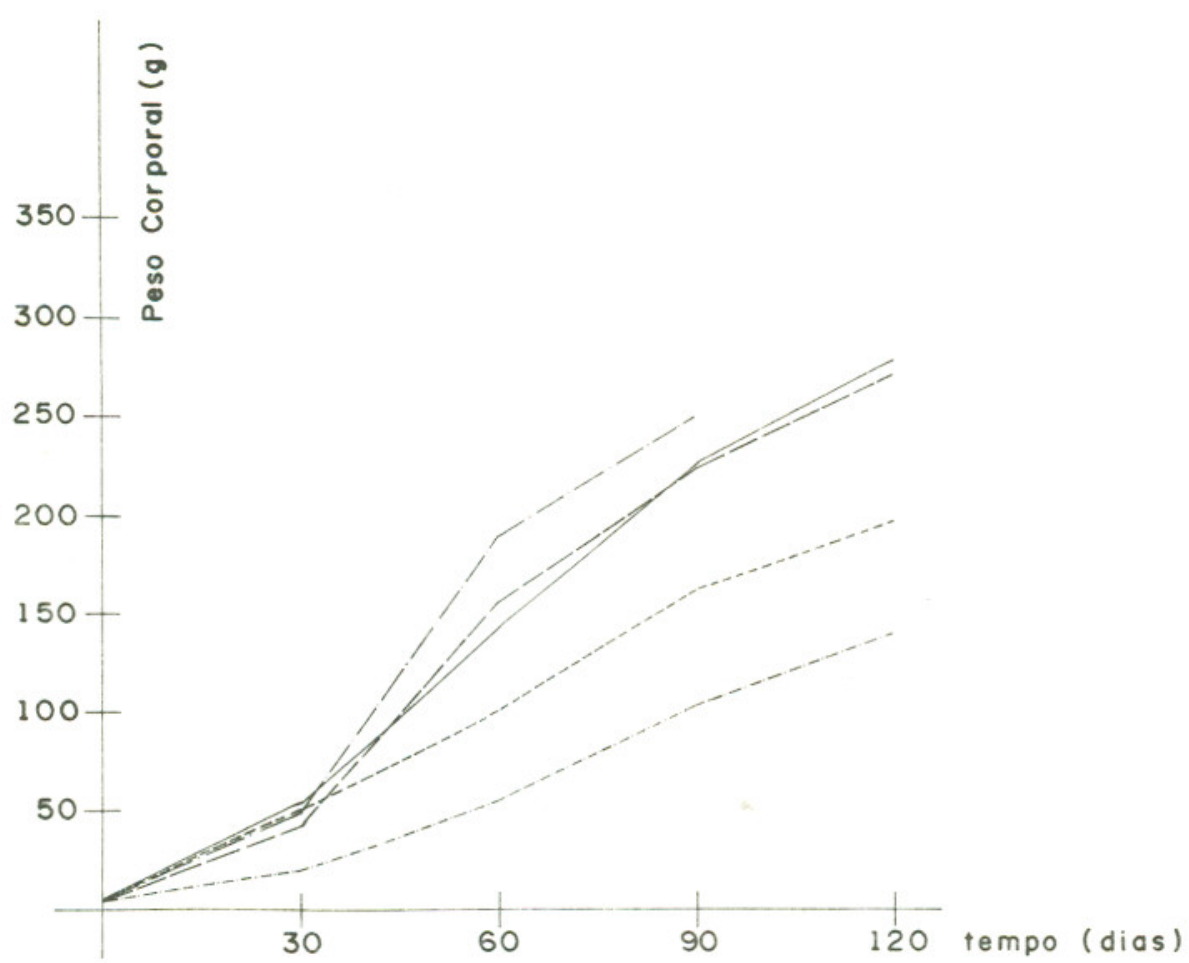

Fig.3-Curva de crescimento, de 3 geraçōes de ratos machos, alimentados com raç⿸es de Caseína e Biomassa ( $10 \%$ de proteína)

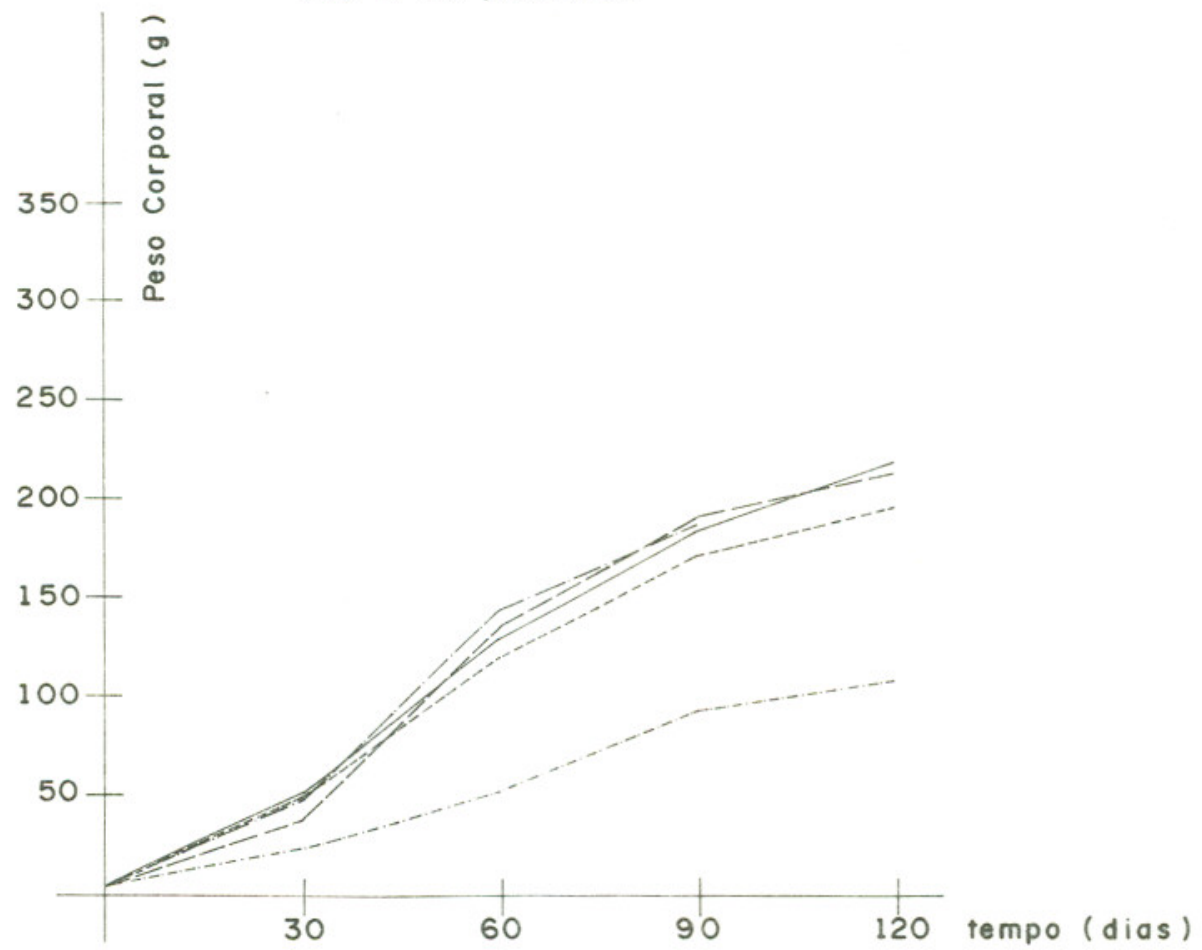

Fig.4 - Curva de crescimento, de 3 geraçöes de ratos fêmeas, alimentados com racōes de Caseína e Biomassa. ( $10 \%$ de proteína) 
TABEla 32 - Médias e desvio padrão do ganho de peso (g), de 3 gerações de animais, alimentados com ração controle de caseina e experimental de biomassa, ao nível protéi co de $25 \%$, nos diferentes periodos da experiência. (COZZOLINO, 1982)

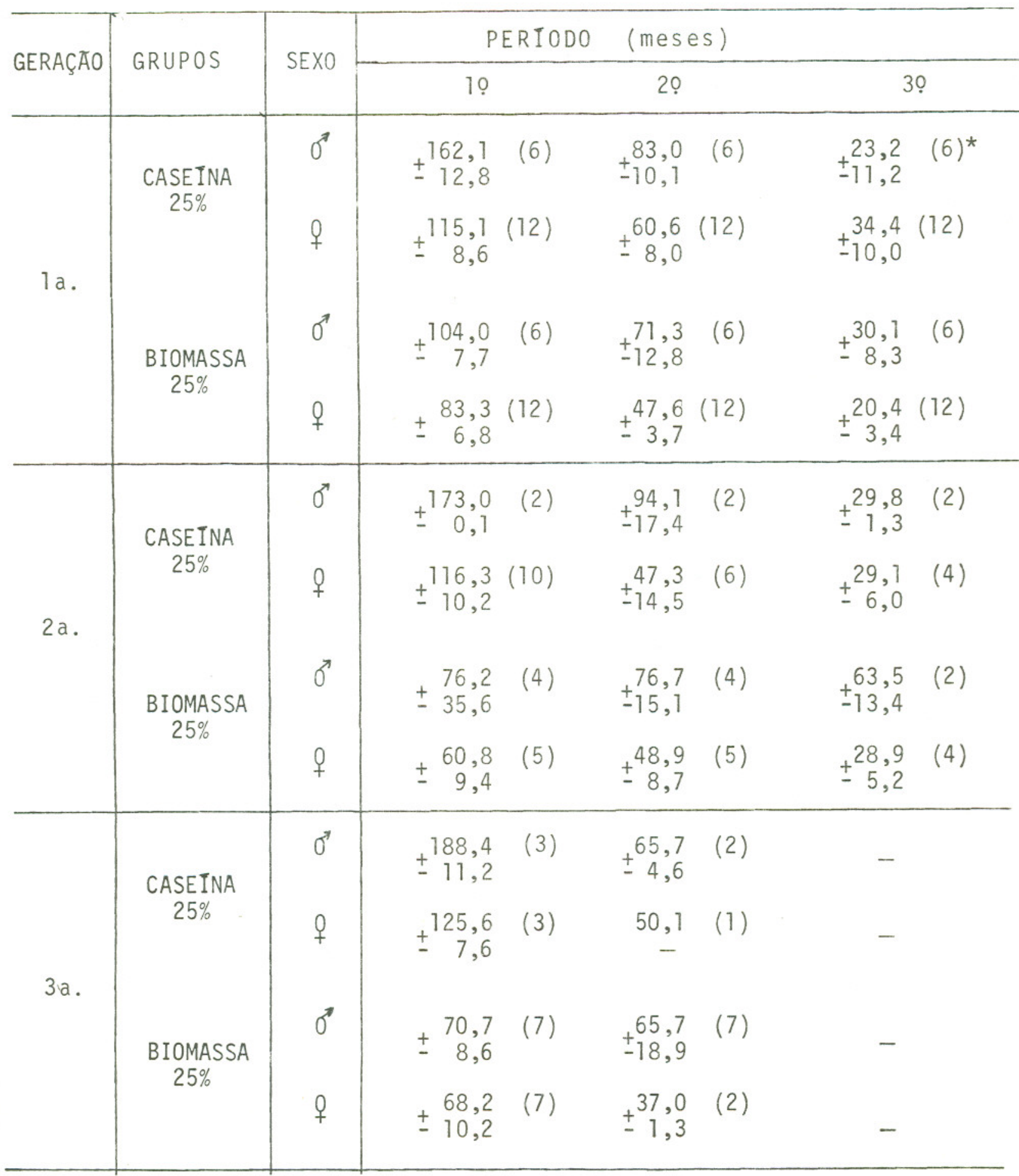

*Entre parenteses o nümero de animais. 
TABELA 33 - Médias e desvio padrão do ganho de peso (g), de 3 gerações de animais, alimentados com ração controle de caseína e experimental de biomassa, ao nīvel protéico de 10\%, nos diferentes períodos da experiência. (COZZOLINO, 1982).

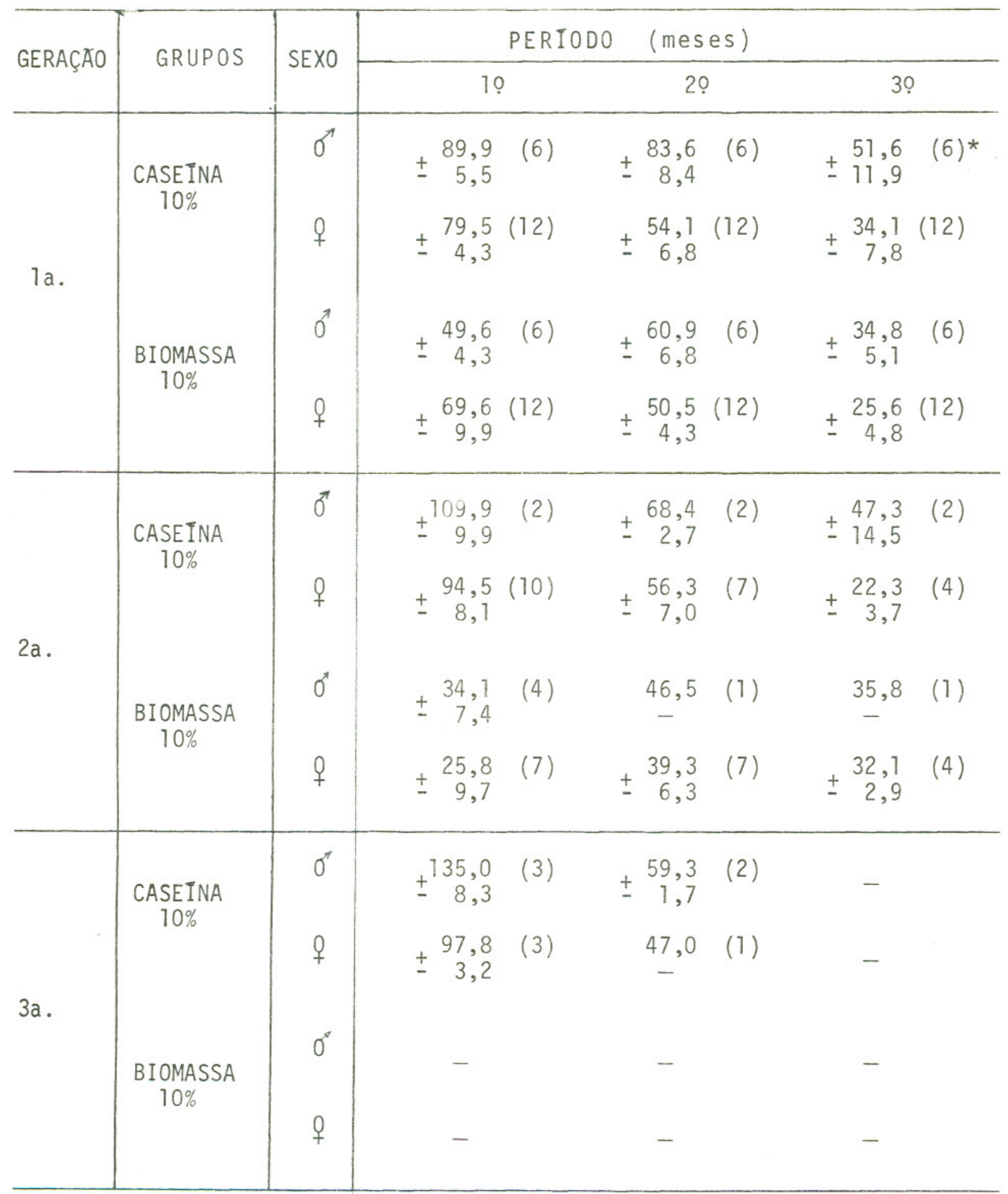

*Entre parenteses o nümero de animais. 
para os grupos de biomassa, com exceção da la. geração, que mostraram uma tendencia para manter o mesmo rítmo de crescimen to atē a fase adulta.

A comparação entre as gerações, demonstrou que não houve diferenças significativas quanto ao desenvolvimento dos animais alimentados com caseĩna de uma geração para outra, o mesmo podendo-se dizer dos animais alimentados combiomassa $25 \%$, embora na primeira geração estes animais tivessem um desenvolvimento mais acentuado durante o primeiro mês em relação às ou tras gerações (Fig. 5 e 6 ). Em relação aos grupos de biomassa 10\%, verificamos que houve diferença no comportamento dos animais em rela ção ao ganho de peso da $1 \mathrm{a}$. e 2a. gerações, principalmente em relação ao primeiro e segundo mês (Fig. 8 e 9).

Quanto às diferenças observadas em relação ao sexo, verificamos que os grupos de caseĩna nos dois nīveis protéicos da ração, mostraram maior ganho de peso para os machos, o mesmo acontecendo para o grupo de biomassa $25 \%$, entretanto, os gru pos de biomassa $10 \%$, não mostraram diferenças quanto ao ganho de peso total, nos 120 dias de experiência.

A anālise do ganho de peso acumulativo dos animais do desmame atē 90 e 120 dias de experiēncia mostrou atravēs das Figuras 7 e 10, que os grupos de animais alimentados com fonte protéica de caseina comportaram-se homoqeneamente para este parametro nas 3 gerações, enquanto que os grupos de animais a1 imentadas com fonte protēica de biomassa apresentaram uma diminuição de ganho de peso nas $2 a$. e 3a. gerações em relação a la. geração. Portanto, verificamos que houve uma exacerbação do efeito da 


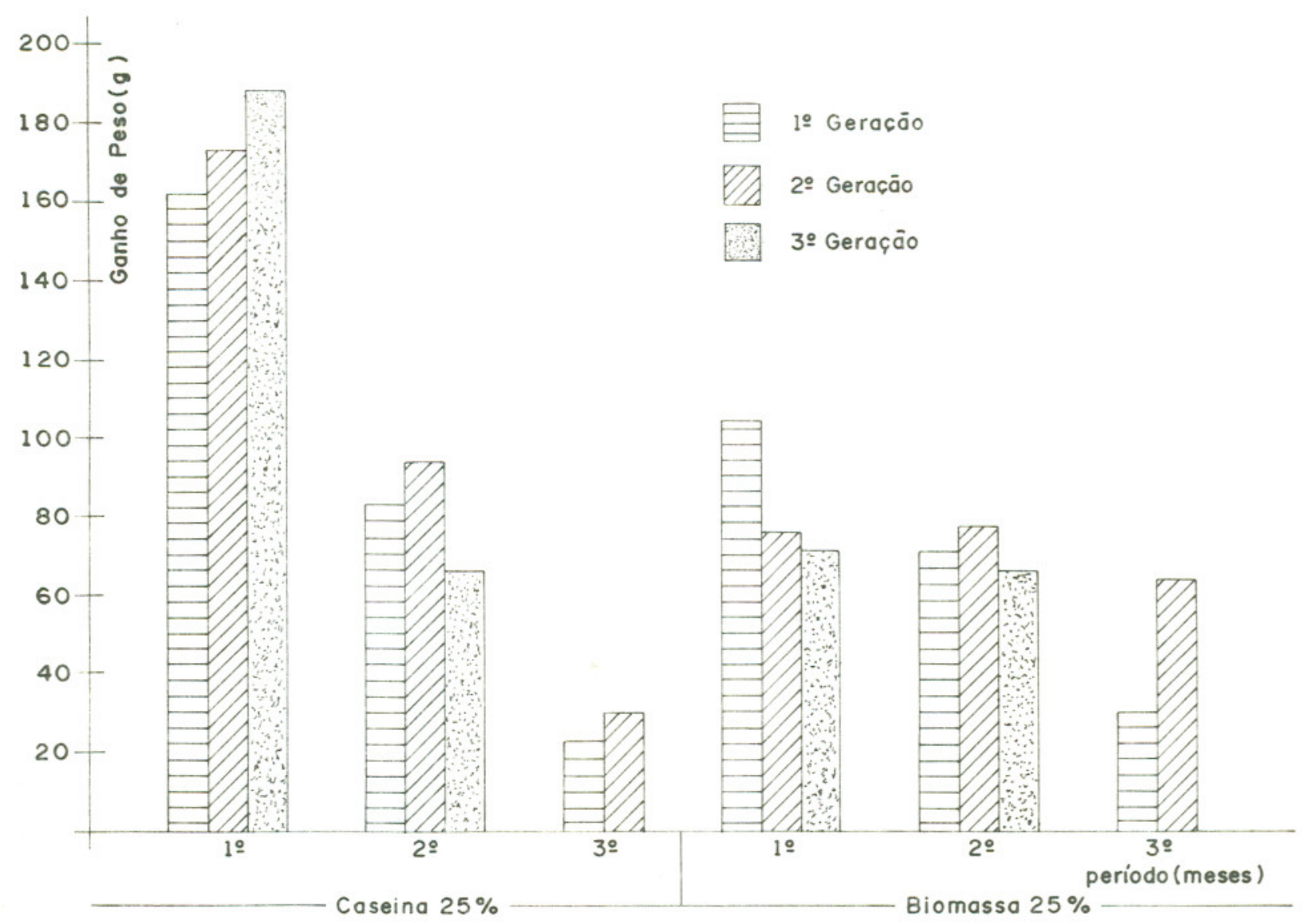

Fig. 5 - Ganho de peso de 3 geraçóes de ratos machos, alimentados com raçóes de Caseina e Biomassa, ao nível protéico de $25 \%$.

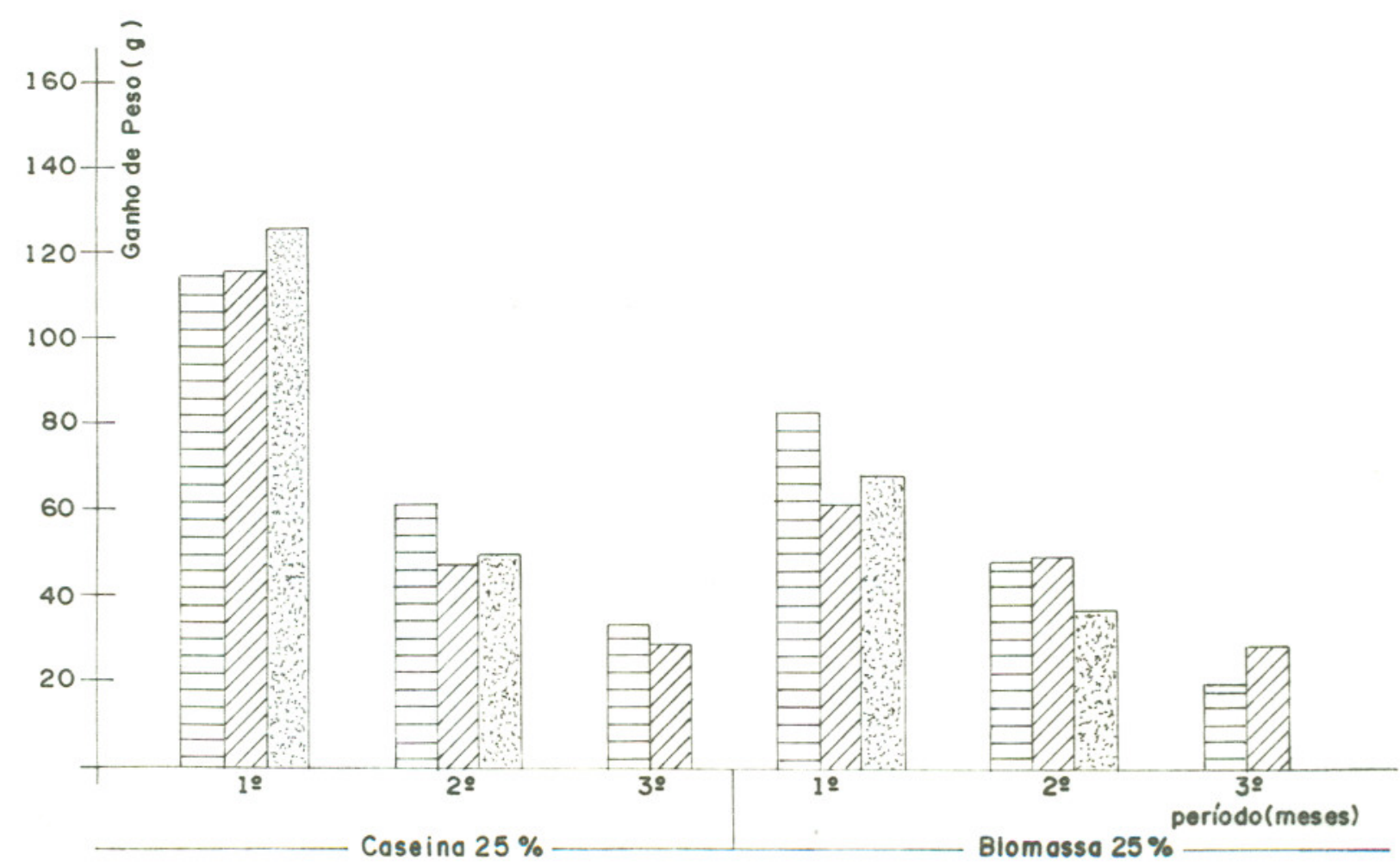

Fig. 6-Ganho de peso de 3 geraçōes de ratos femeas, alimentados com raçóes de Caseína e Biomassa, ao nível protéico de $25 \%$. 

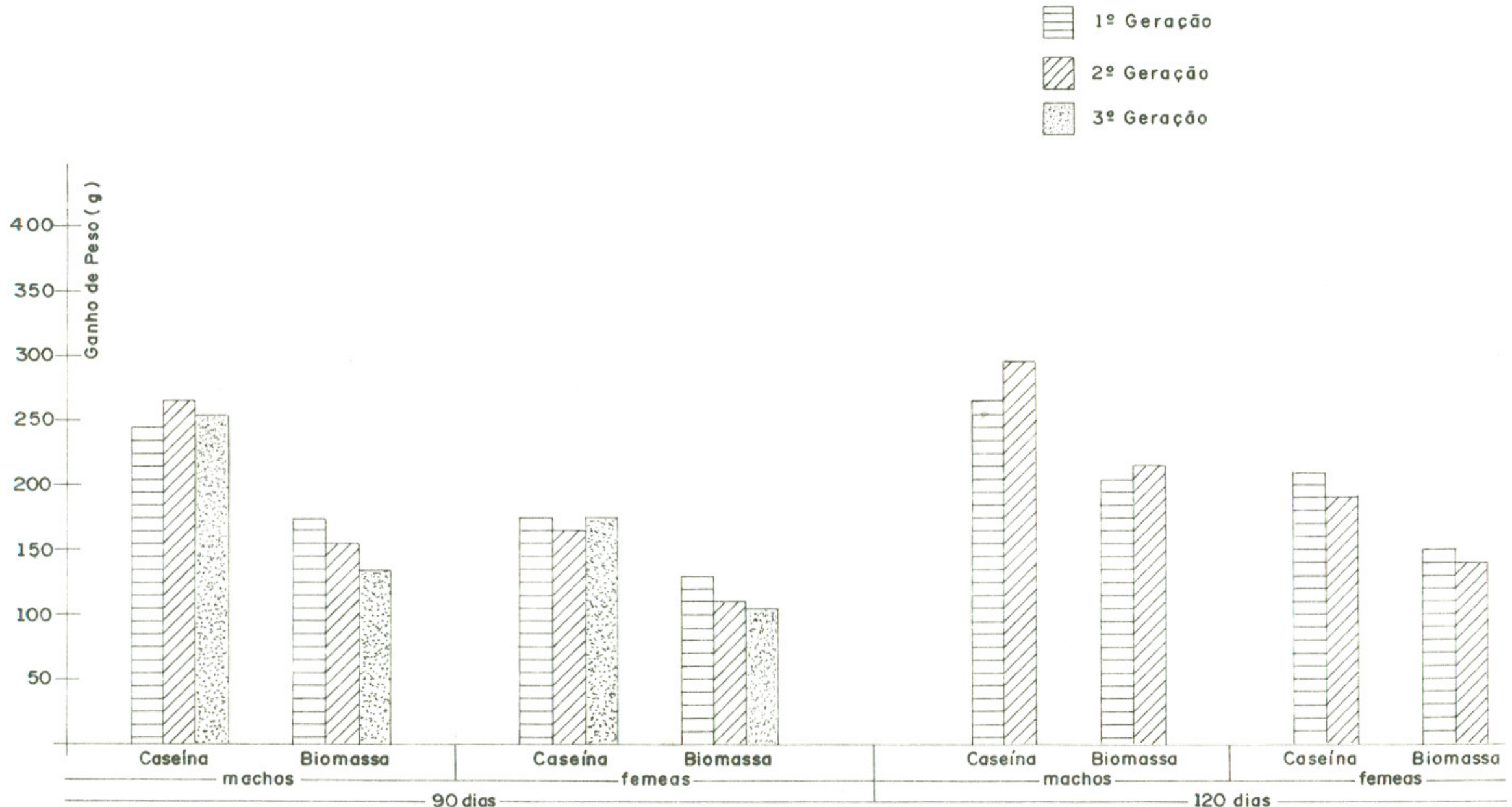

Fig. 7 - Ganho de peso, do desmame até 90 e 120 dias, de 3 geraçōes de animais alimentados com raços de Caseína e Biomassa, ao nível protéico de $25 \%$. 


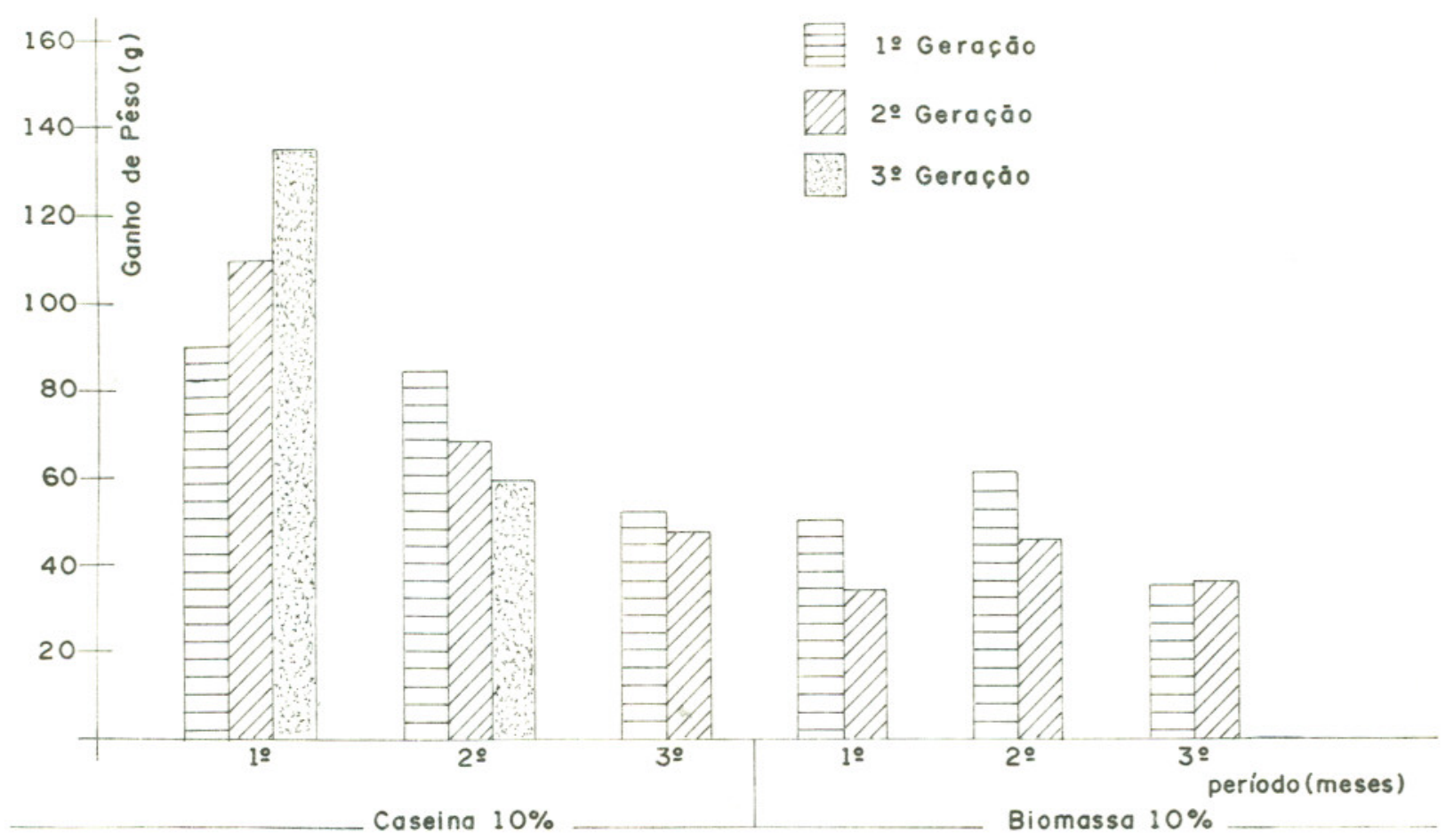

Fig. 8 - Ganho de peso de 3 geraçōes de ratos machos, alimentados com raçōes de Caseína e Biomassa, ao nível protéico de $10 \%$.

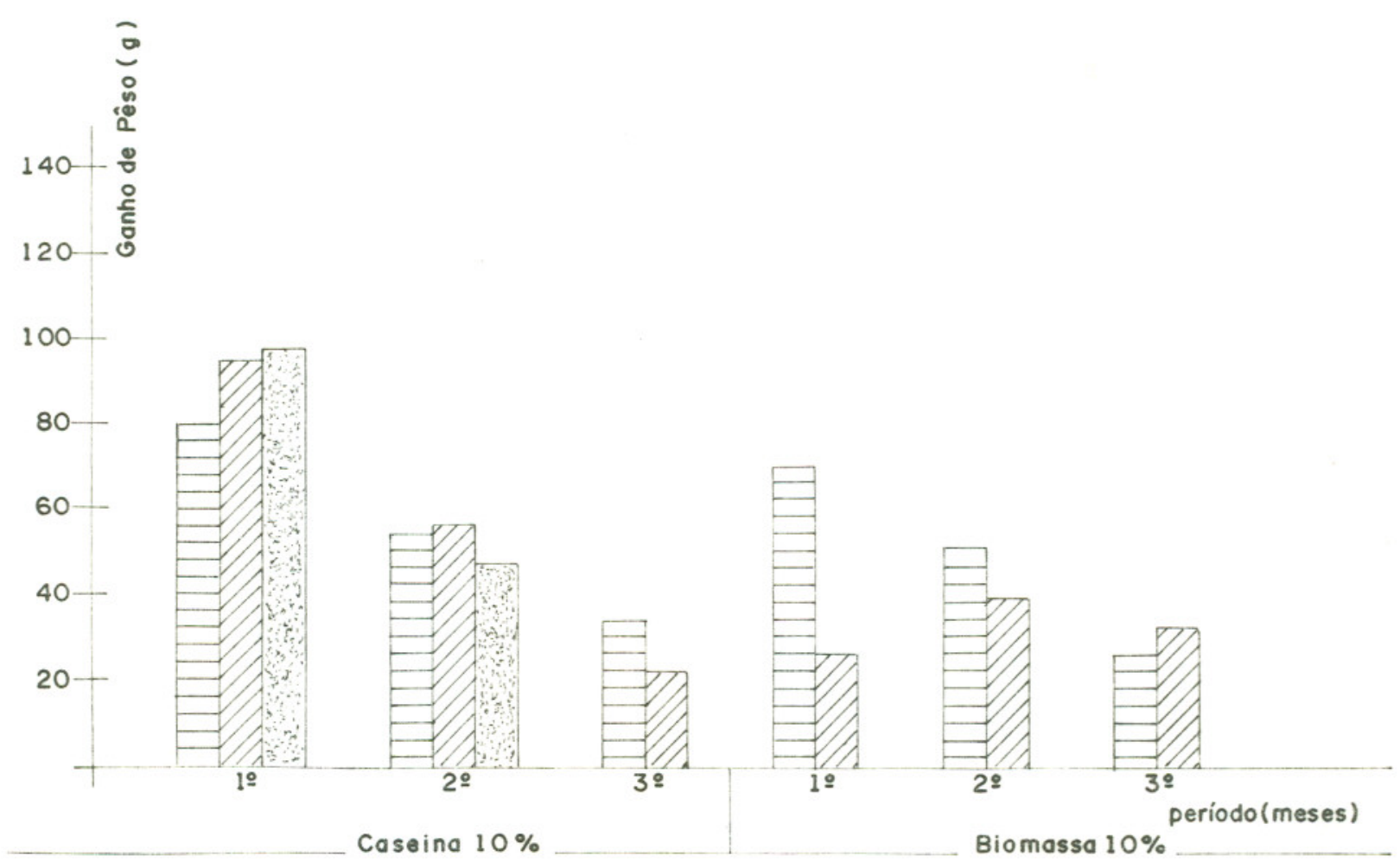

Fig.9-Ganho de peso de 3 geraçōes de ratos femeas, alimentados com raçōes de Caseína e Biomassa, ao nivel protéico de $10 \%$. 

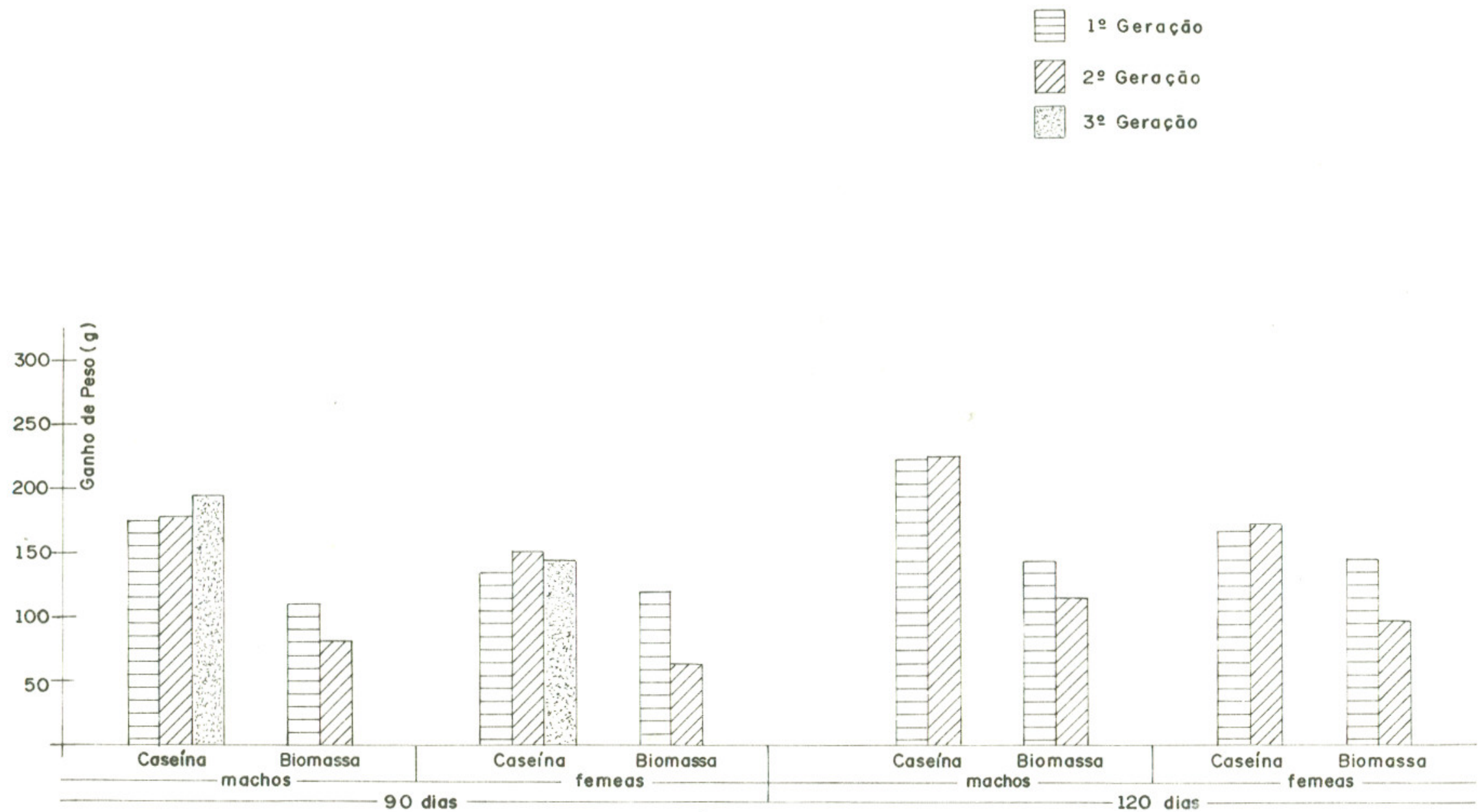

Fig.10 - Ganho de peso, do desmame até 90 e 120 dias, de 3 geraçōes de animais alimentados com raçōes de Caseína e Biomassa, ao nível protéico de $10 \%$. 
ração, no desenvolvimento dos animais de uma geração para outra. Assim, a desnutrição provocada por uma ração deficiente, pode ter promovido uma diminuição da capacidade absortiva dos animais das gerações seguintes, conforme estudado por vārios autores $(38)(82)(96)(126)$, que foi inicialmente atenuada pela capaci dade de adaptação do animal. Porēm, quando a desnutrição atin giu seu ponto crïtico, houve impedimento atë da reprodução.

os dados referentes a consumo de ração e de proteĩna, como jā dissemos anteriormente, desempenha papel significativo nas determinações dos coeficientes de eficäcia alimentar e proteĩca, assim, rapidamente procuraremos atravēs das Tabelas 34 a 37 e Figuras de 11 a 22 , demonstrar o comportamento dos animais experimentais em relação a estes parāmetros.

Como jä discutimos no ensaio preliminar, alguns animais, neste caso o rato, possuem a capacidade instintiva de selecionar seus alimentos, assim, se existe a possibilidade de escolha, estes selecionam as rações mais balanceadas. Värios experimentos comprovam este fato, entretanto, se não existe a possibilidade de escolha, hä uma tendēncia no sentido de inge rirem menor quantidade de ração, e consequentemente, de protệ na . Portanto, verificamos que o consumo de ração e de proteí na entre os grupos de animais machos alimentados com ração de caseỉna e biomassa ao nỉvel protēico de $25 \%$, na primeira geração, praticamente não apresentou diferença no total de ração consumida, o mesmo podendo-se dizer em relação às fēmeas, sendo entretanto inferiores para as fëmeas em relação aos machos. Na segunda geração, observamos que o consumo da ra- 
TABELA 34 - Médias e desvio padrão do consumo de ração (g), de 3 gerações de animais, alimentados com ração controle de caseina e experimental de biomassa, ao nivel pro teíco de $25 \%$, nos diferentes períodos da experiên cia. (COZZOLINO, 1982).

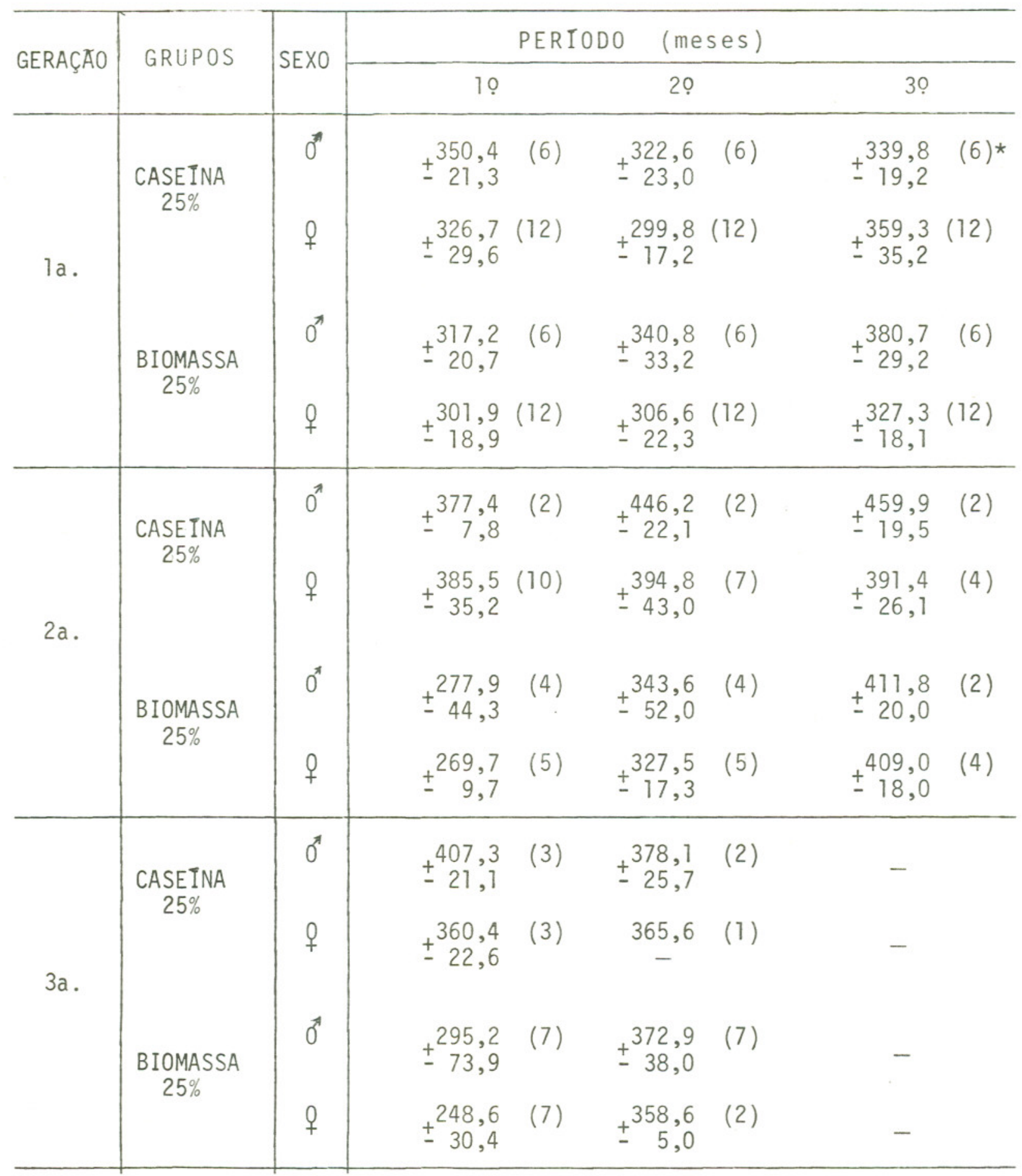

* Entre parenteses o nūmero de animais. 
TABEla 35 - Médias e desvio padrão do consumo de proteína (g) , de 3 gerações de animais, alimentados com ração controle de caseỉna e experimental da biomassa, ao nível protéico de $25 \%$, nos diferentes períodos da expe riēncia. (COZZOLINO, 1982).

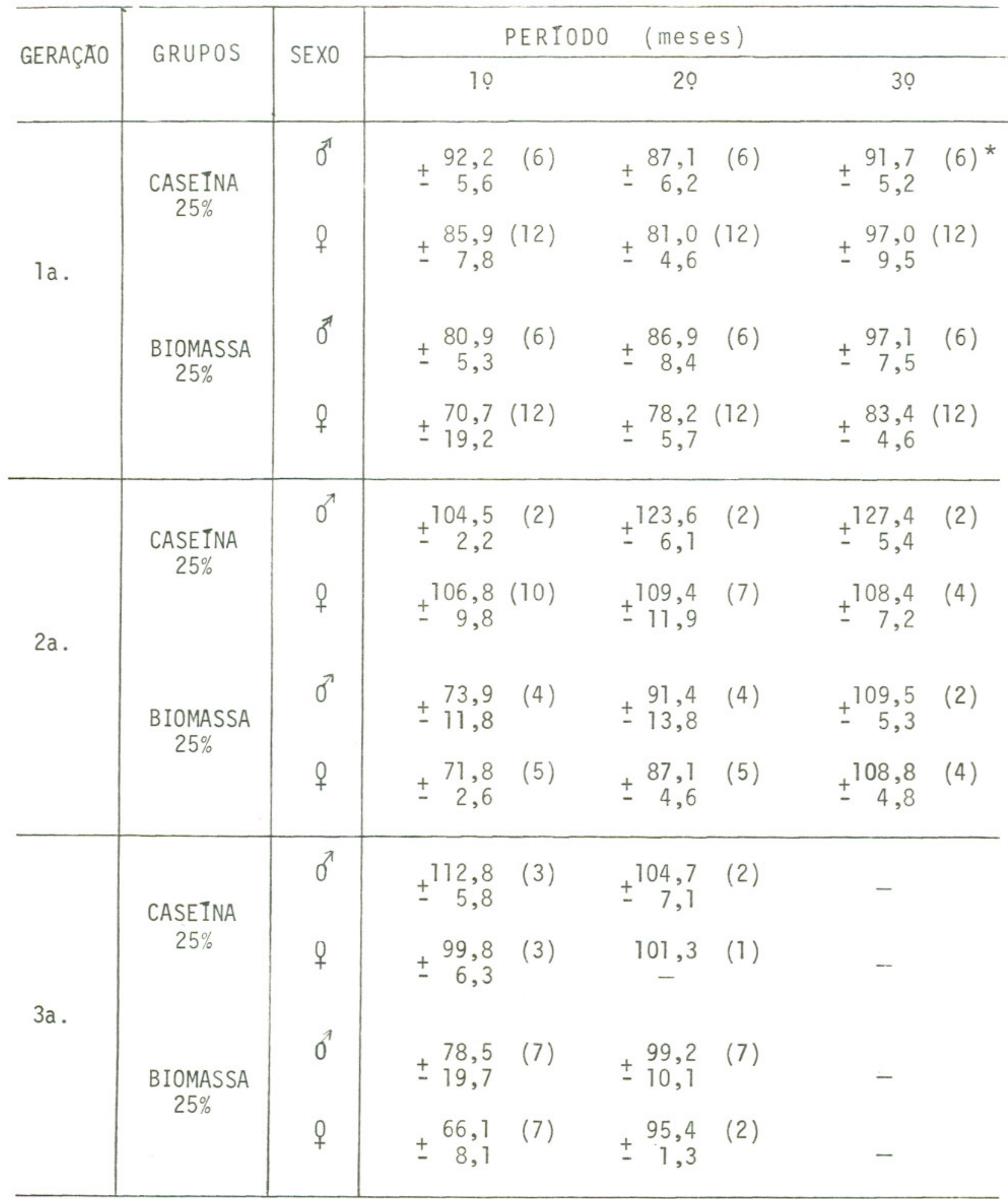

*Entre parenteses o nümero de animais. 


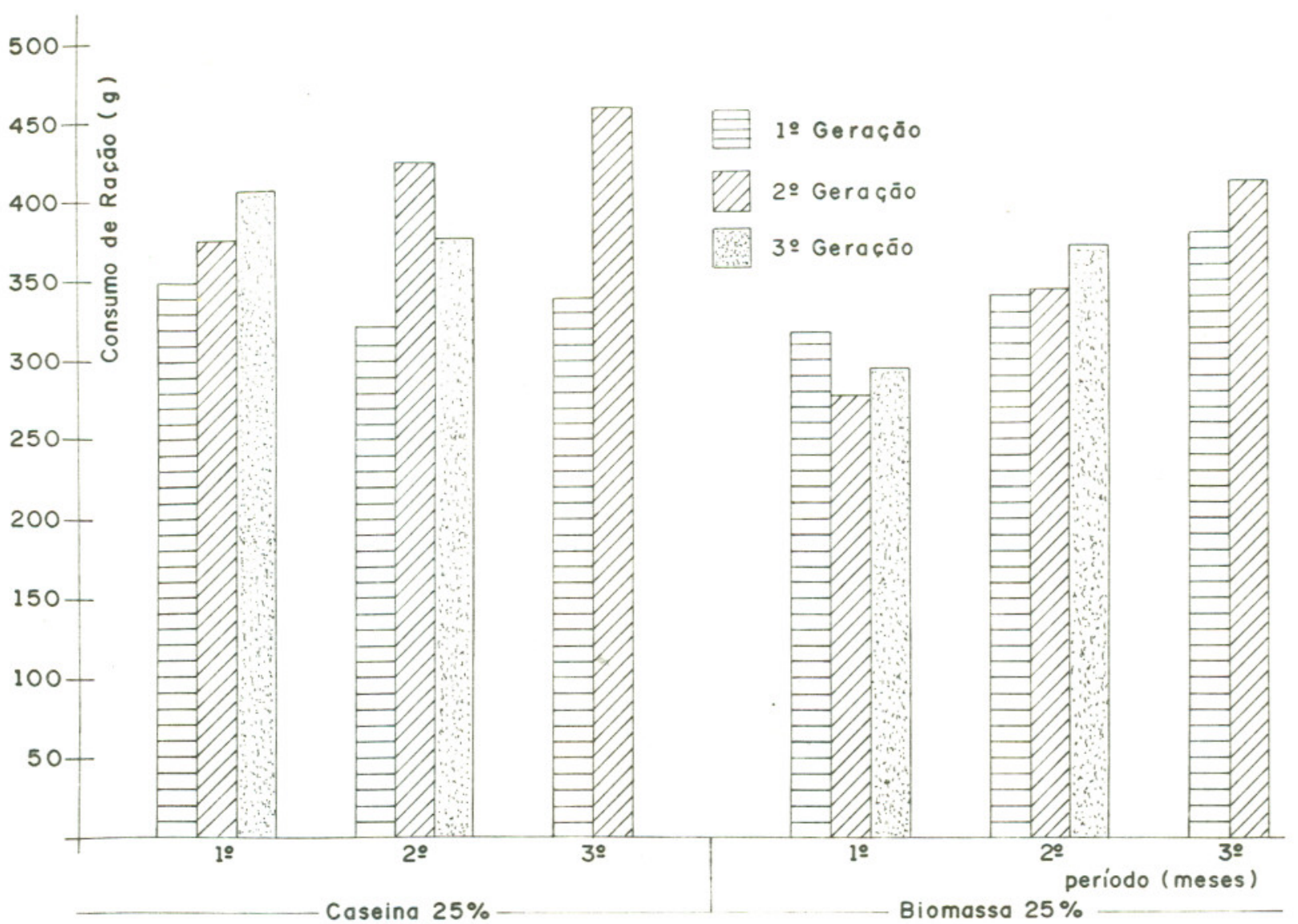

Fig. 11 - Consumo de racão de 3 geraçóes de ratos machos, alimentados com raçōes de Caseína e Biomassa, ao nível protéico de $25 \%$.

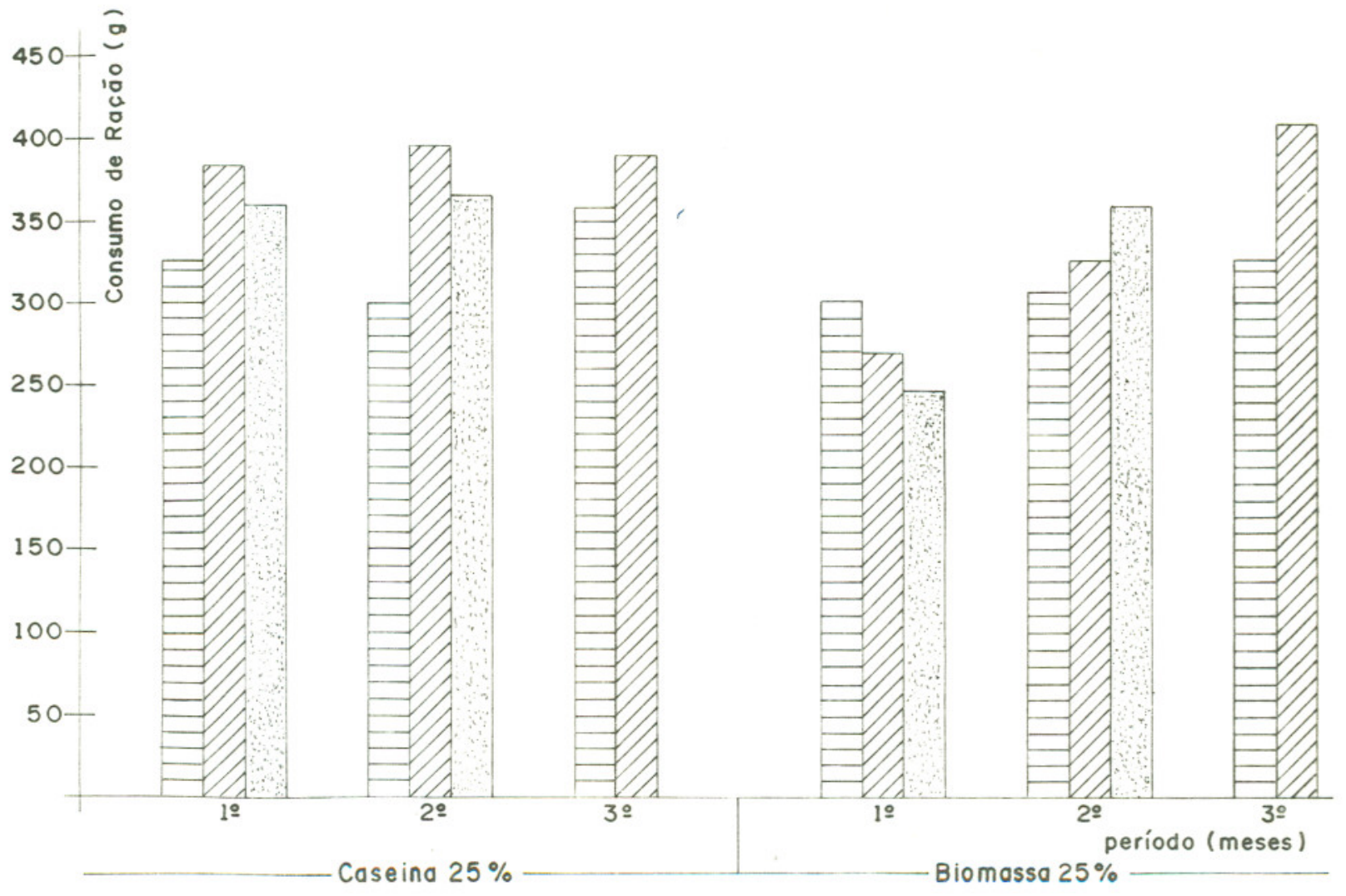

Fig.12 - Consumo de raçāo de 3 geraçōes de ratos femeas, alimentados com raçōes de Caseína e Biomassa, ao nível protéico de $25 \%$. 


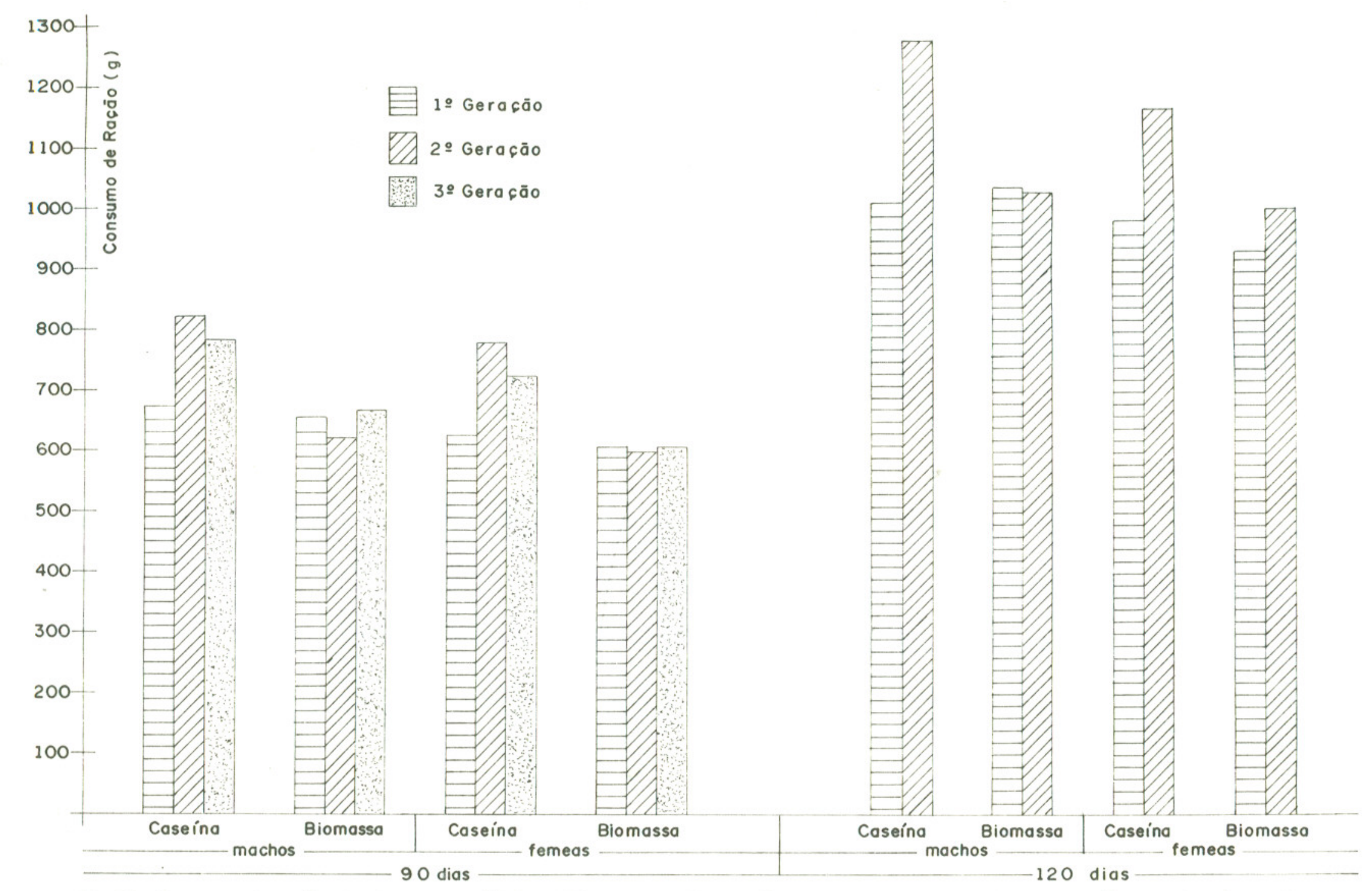

Fig. 13 - Consumo de raçāo, do desmame até 90 e 120 dias, de 3 geraçōes de animais alimentados com raçōes de Caseína e Biomassa, ao nível protéico de $25 \%$ 


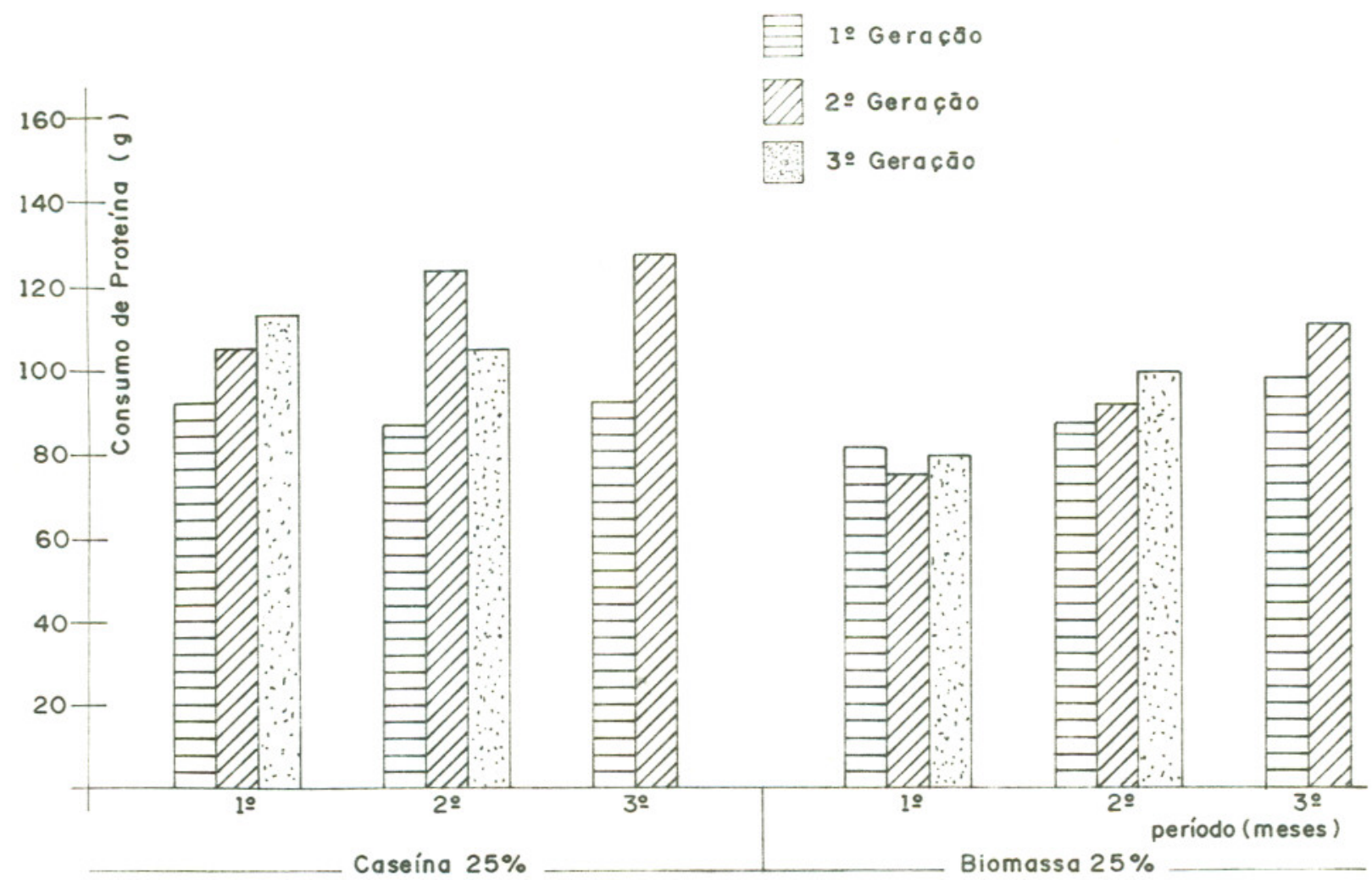

Fig. 14 - Consumo de proteina de 3 geraçōes de ratos machos, alimentados com raçỏes de Caseína e Biomassa, ao nivel protéico de $25 \%$.

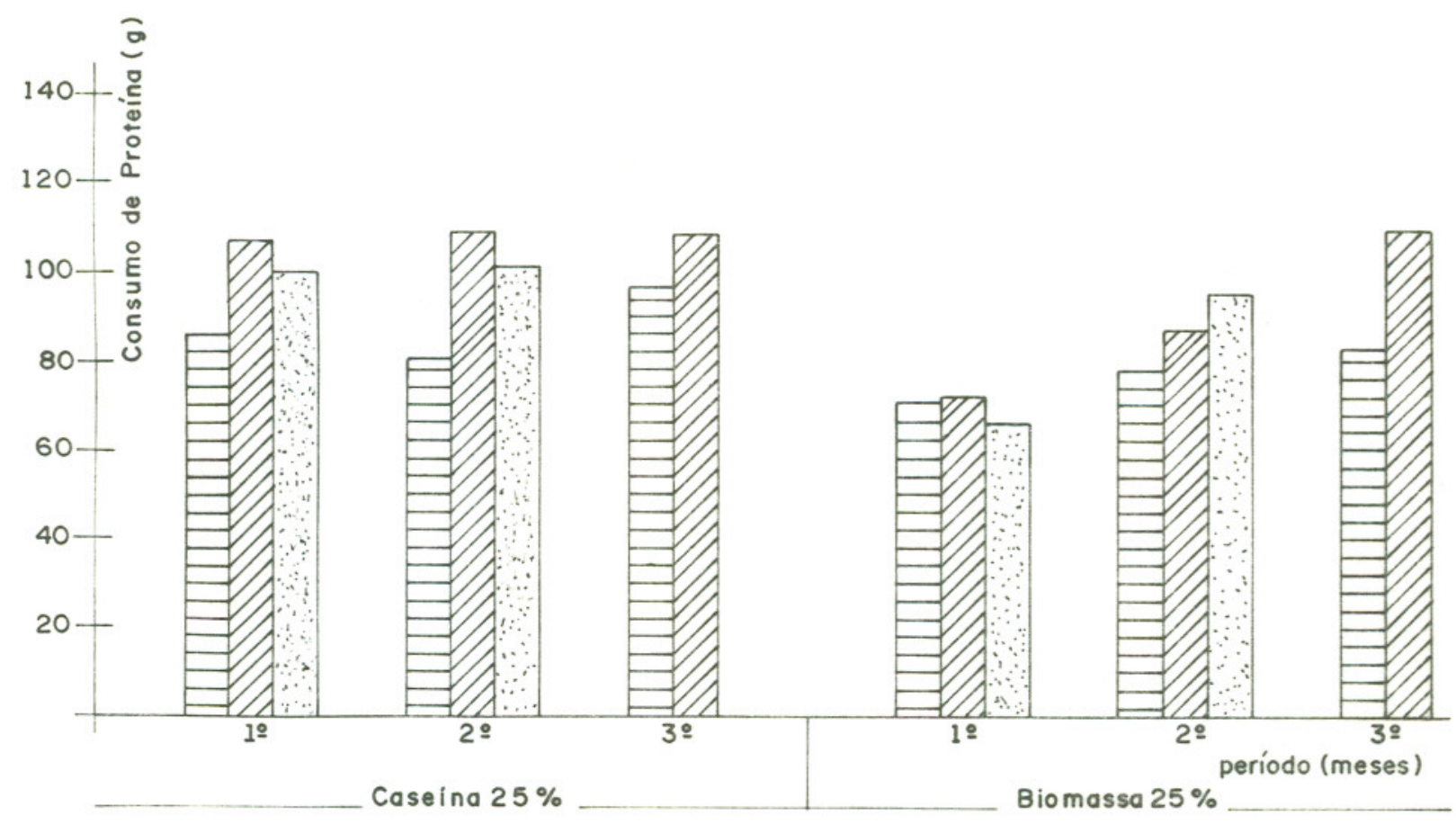

Fig. 15 - Consumo de proteína de 3 geraçōes de ratos femeas, alimentados com raçōes de Caseína e Biomassa, ao nível protéico de $25 \%$. 

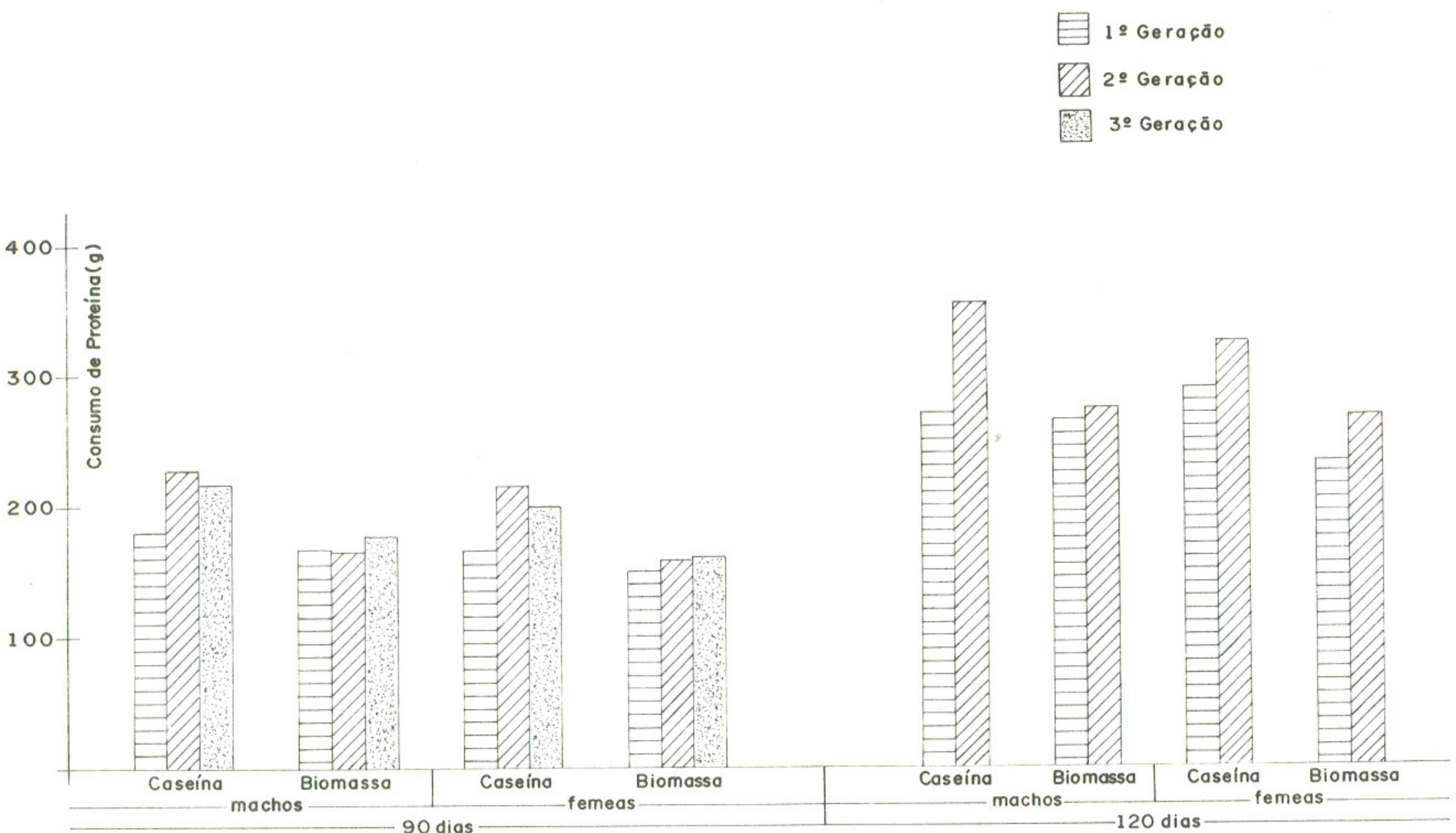

Fig. 16 - Consumo de proteina, do desmame até 90 e 120 dias, de 3 geraçōes de animais alimentados com racōes de Caseína e Biomassa, ao nivel protéico de $25 \%$. 
ção foi superior para os grupos de animais machos alimentados com ração controle de caseĩna ao nĩvel protēico de $25 \%$ em rela ção aos grupos experimentais de biomassa, o mesmo ocorrendo em relação às fêmeas.

$\mathrm{Na} 3 a$. geração, o mesmo pode ser verificado, sendo que os grupos experimentais de biomassa, apresentaram valores inferiores para consumo de ração e proteīna em relação aos grú pos controle de caseina, da ordem de $15 \%$ e $16 \%$, respectivamente, para machos e fêmeas.

Em relação aos grupos de caseĩna $10 \%$ e biomassa $10 \%$, verificamos que o consumo de ração e proteĩna nas Tabelas 36 e 37 e Figuras de 17 a 22 para os animais machos na primeira gera ção, foi superior para o grupo de caseỉna, o mesmo não ocorren do em relação às fêmeas, cujo consumo foi praticamente o mesmo para os dois grupos. Na 2a. geração, verificamos que o con sumo foi inferior para os grupos de biomassa tanto para machos como para fêmeas, percentualmente, os grupos experimentais de biomassa tiveram consumo de ração inferiores aos grupos contro le de caseina $37 \%$ e $31 \%$ para machos e fêmeas respectivamente.

Portanto podemos concluir, que o consumo de ração e proteĩna, não apresentaram variações de uma geração para outra, quando o teor protëico foi de $25 \%$ na ração, o mesmo acontecendo em relação aos grupos de caseína ao nîvel protēico de $10 \%$ na ração, não ocorrendo o mesmo para os grupos de animais alimentados com ração de biomassa ao nỉvel protëico de 10\%, onde observamos um declīnio em relação a primeira geração. Verifí camos, tambēm, que na maioria das vezes, os grupos alimentados 
TABELA 36 - Médias e desvio padrão do consumo de ração (g), de 3 gerações de animais, alimentados com ração controle de caseîna e experimental de biomassa, ao nível pro teíco de $10 \%$, nos diferentes periodos da experiên cia. (COZZOLINO, 1982).

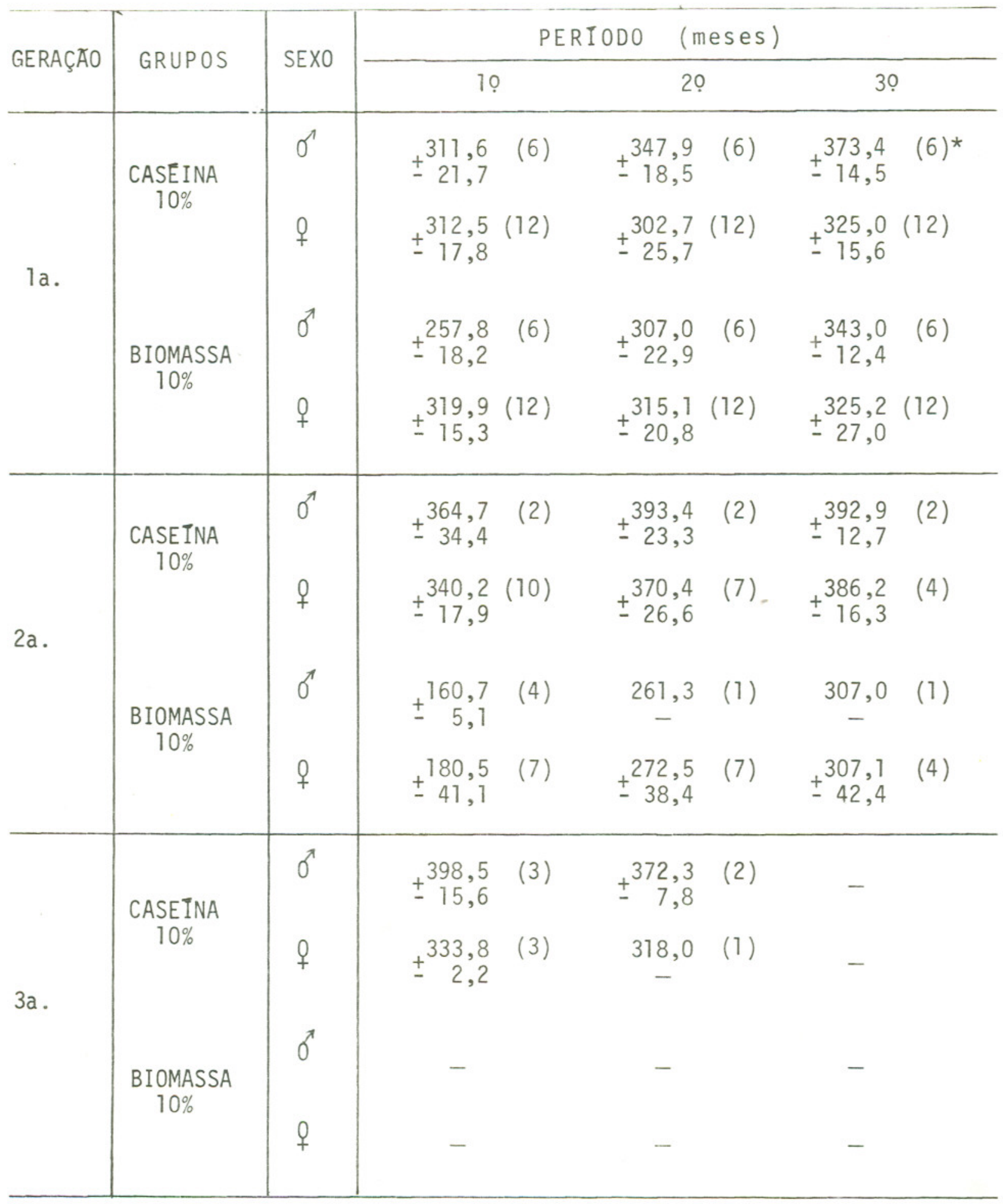

*Entre parenteses o nūmero de animais. 
TABELA 37 - Médias e desvio padrão do consumo de proteína (g), de 3 gerações de animais, alimentados com ração con trole de caseina e experimental de biomassa, ao ní vel protéico de $10 \%$, nos diferentes periodos da experiência. (COZZOLINO, 1982).

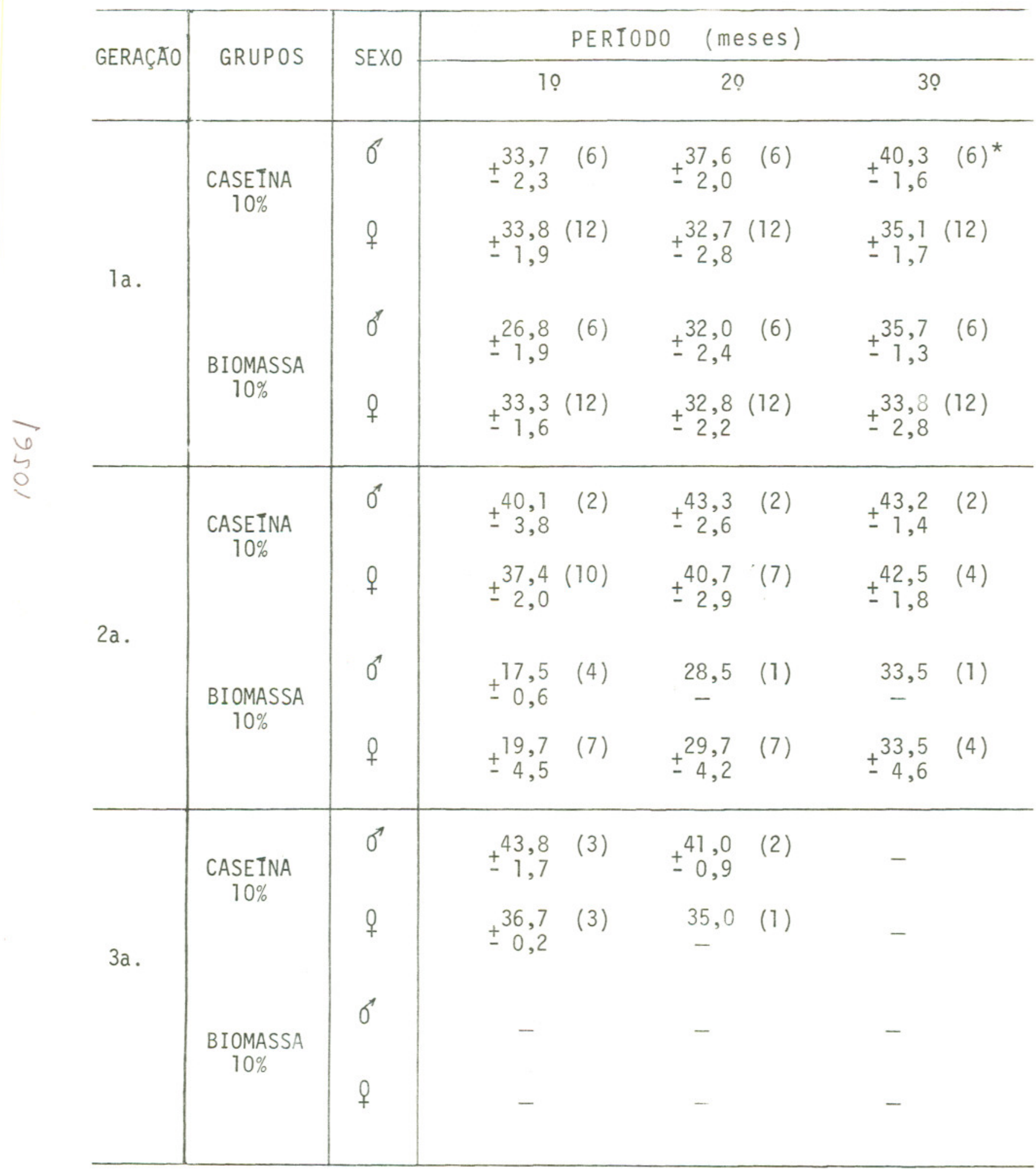

*Entre parenteses o número de animais. 


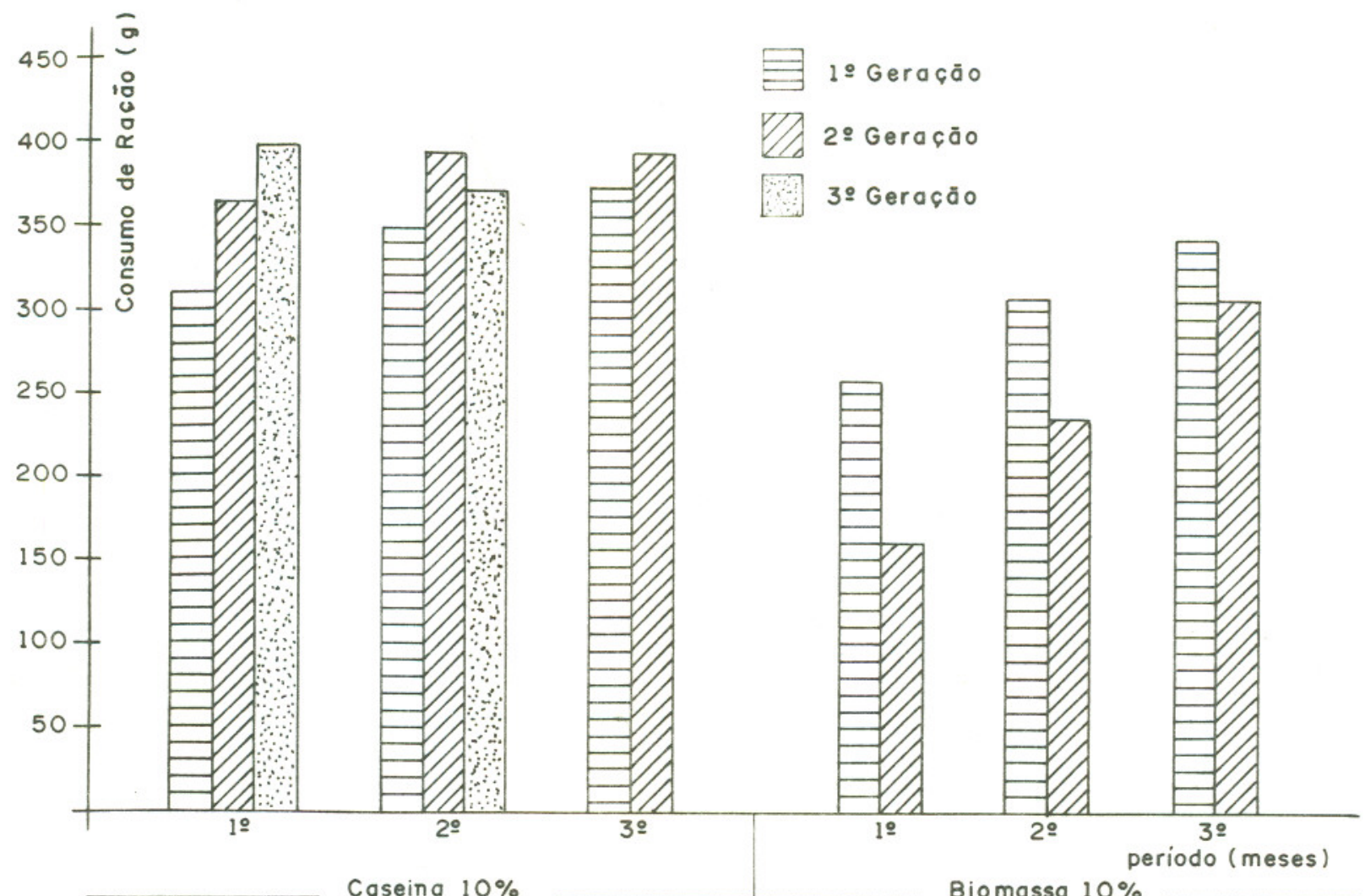

Fig. 17 - Consumo de raçāo de 3 geracōes de ratos machos, alimentados com raçóes de Caseína e Biomassa, ao nível protéico de $10 \%$.

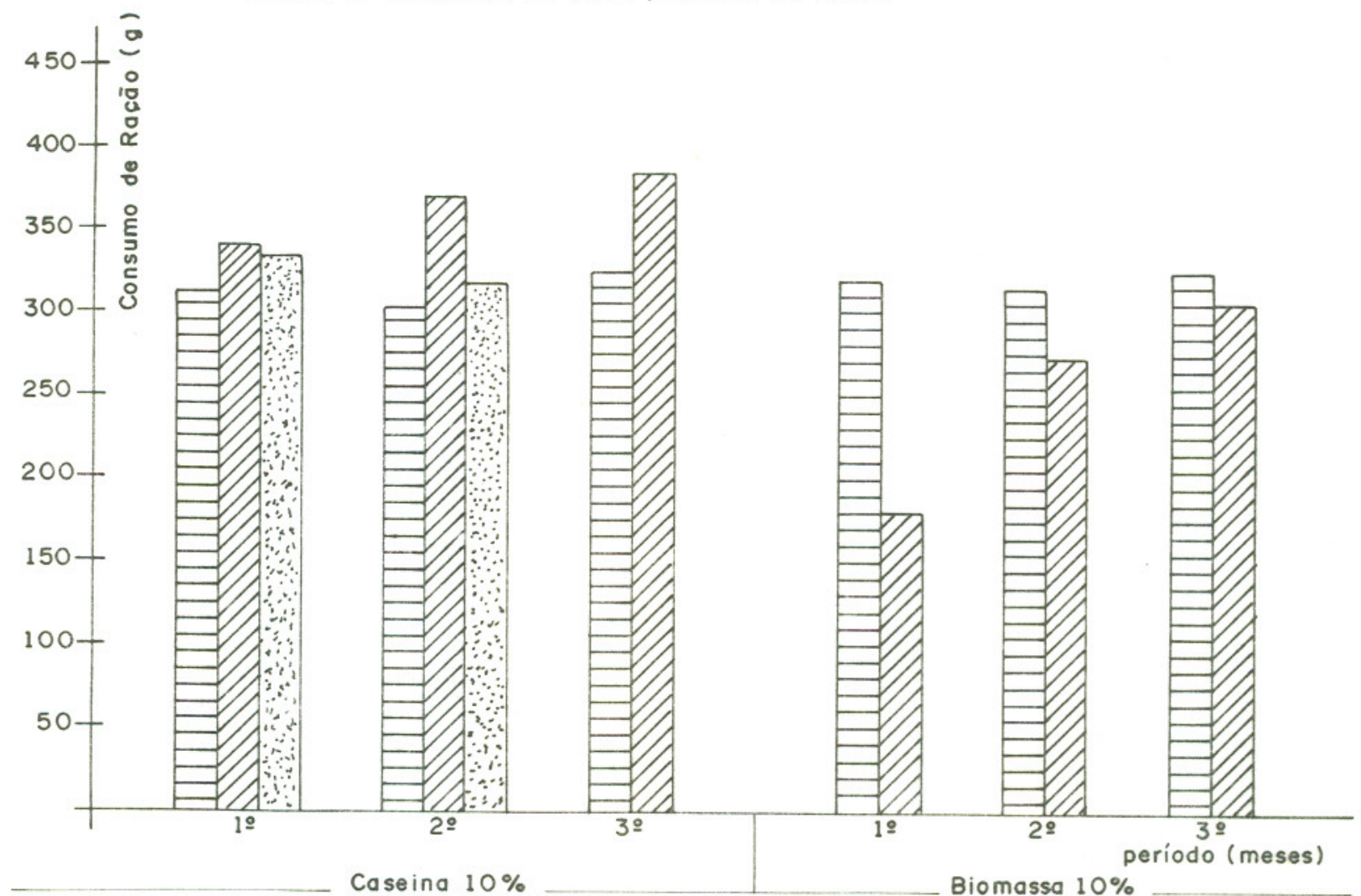

Fig.18 - Consumo de raçāo de 3 geraçōes de ratos femeas, alimentados com raçōes de Caseína e Biomassa, ao nivel protéico de $10 \%$. 


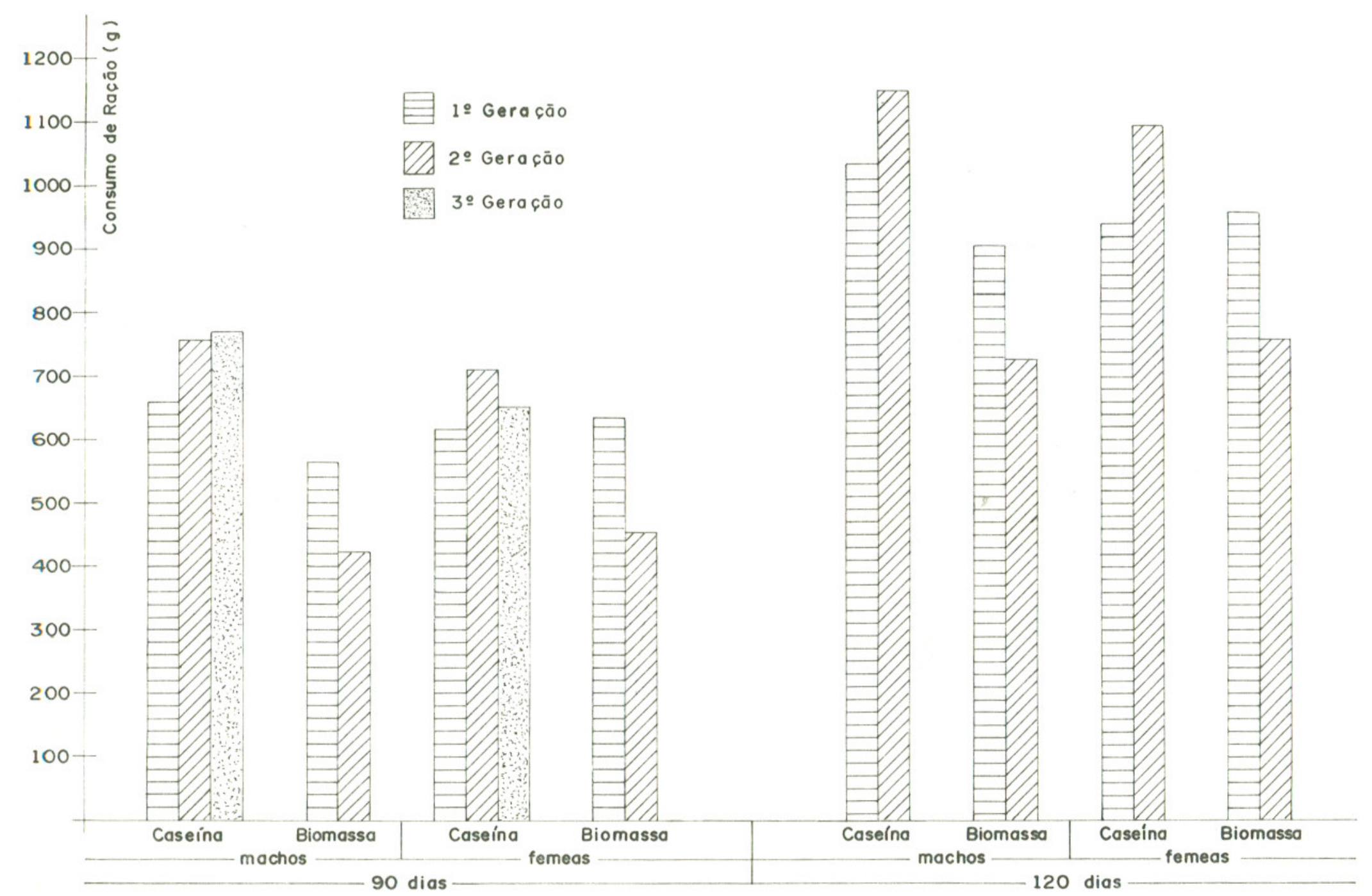

Fig. 19 - Consumo de raçāo, do desmame até 90 e 120 dias, de 3 geraçōes de animais alimentados com raçōes de Caseina e Biomassa, ao nivel protéico de $10 \%$ 


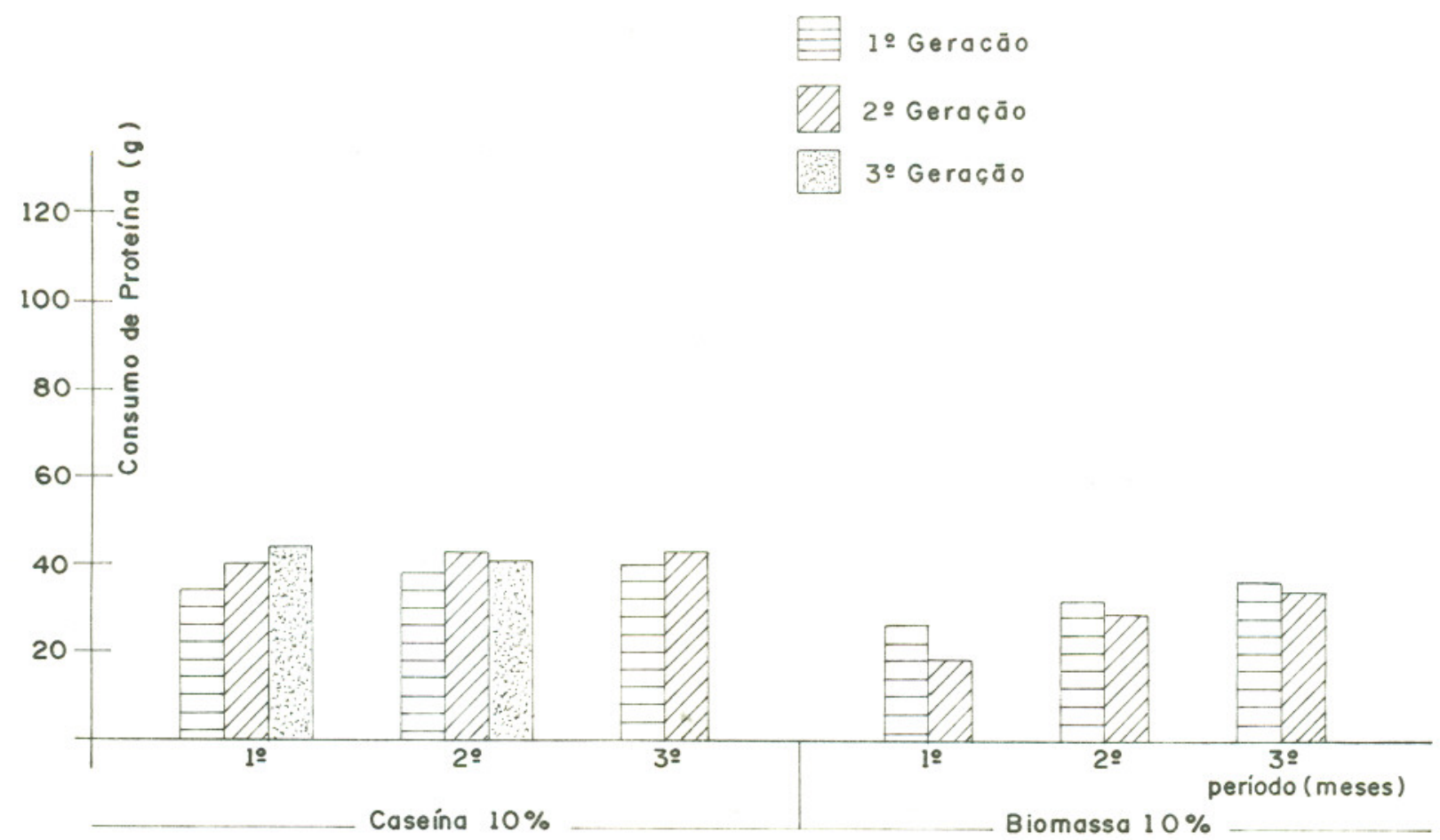

Fig. 20 - Consumo de proteína de 3 geraçōes de ratos machos, alimentados com raçōes de Caseína e Biomassa, ao nível protéico de $10 \%$.

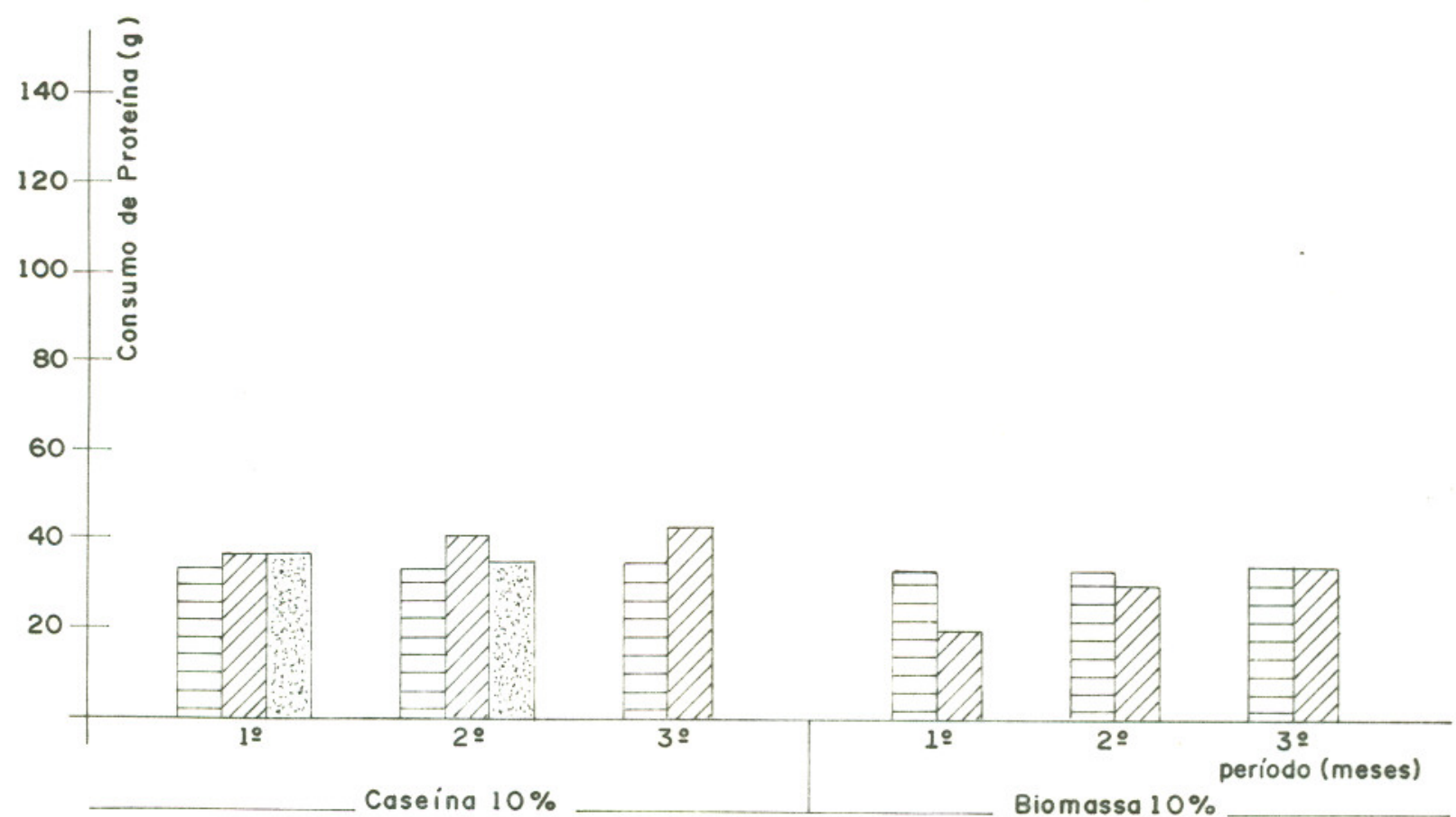

Fig.21 - Consumo de proteína de 3 geraçōes de ratos fẹmeas, alimentados com raçōes de Caseina e Biomassa, a nivel protéico de $10 \%$ 

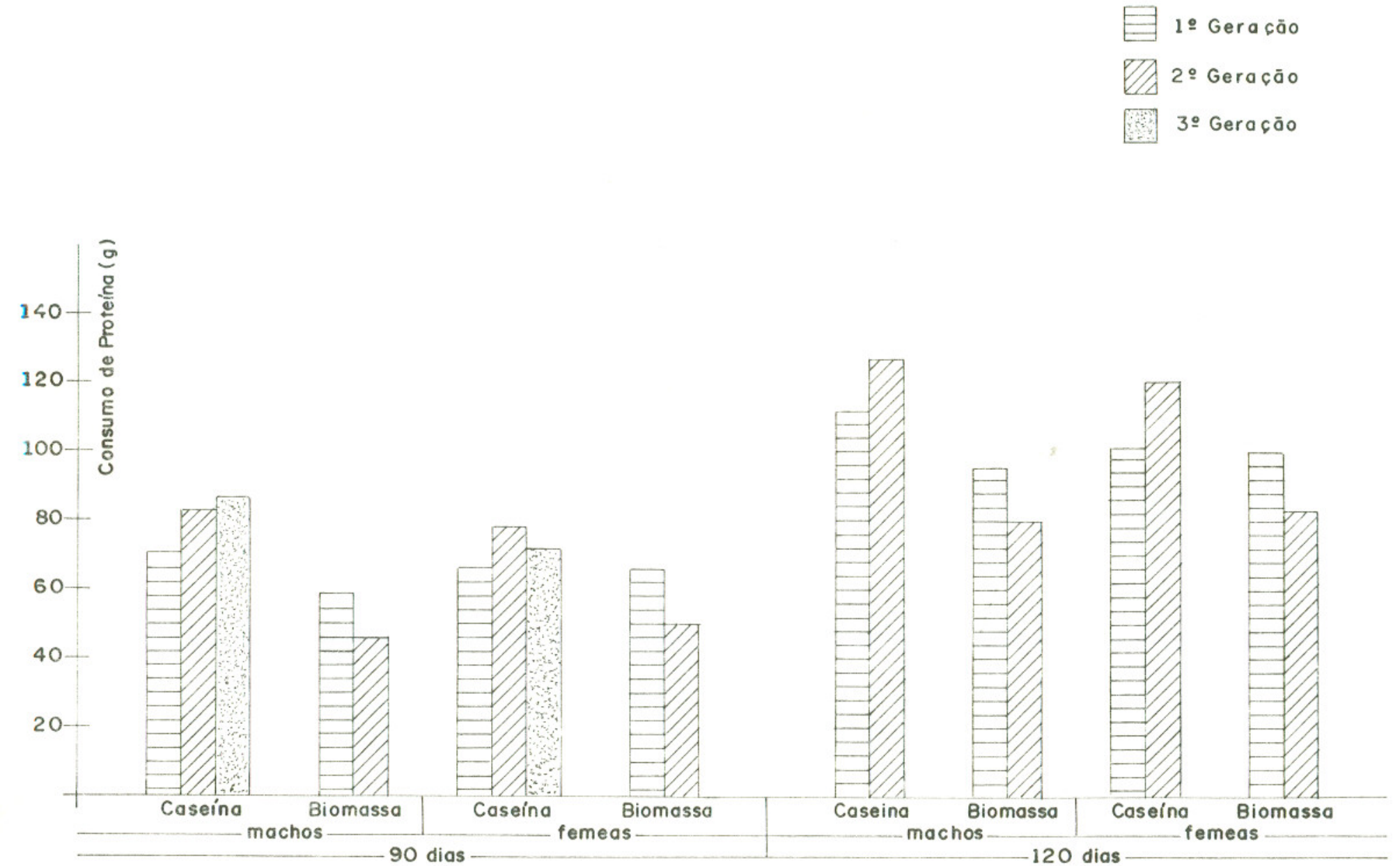

Fig. 22 - Consumo de proteína, do desmame até 90 e 120 dias, de 3 geraçōes de animais alimentados com raçöes de Caseína e Biomassa, ao nivel protéico de $10 \%$. 
com ração controle de caseína, ingeriram maior quantidade de ração, em relação aos grupos experimentais, como pode ser observado atravēs das Figuras 13, 16, 19 e 22.

Desta forma pudemos calcular os coeficientes de eficācia alimentar (CEA) e protēica (CEP) das rações.

As mesmas considerações anteriormente descritas, são novamente colocadas em evidência, pois atravēs destas anāilises podemos avaliar o comportamento desta fonte protēica neste estudo de gerações.

Verificamos que no experimento de curta duração, a fonte protēica de biomassa apresentou bons resultados, entre tanto, verificamos que neste estudo mais longo, houve diferenças de comportamento, como jä salientado nas considerações quan to a indice de crescimento e consumo de ração e proteinna.

Portanto, passamos a discutir os resultados obtidos para CEA e CEP, durante as gerações, baseando-nos em diferen ças observadas dentro do mesmo grupo de uma geração para outra, bem como comparativamente entre os diferentes tratamentos observados, levando-se ainda em consideração o efeito relacionado ao sexo.

Assim, nas Tabelas de 38 a 41 e Figuras de 23 a 34 , apresentamos os resultados obtidos para estes parāmetros, analisados nos diferentes períodos da experiência, bem como atravēs de dados acumulativos ao final desta.

os grupos controle, nos dois nîveis protēicos estuda dos, quando comparados em relação às gerações não mostraram diferenças significativas, comportando-se normalmente de acordo 
com o esperado.

Assim, os grupos de animais machos apresentaram coeficientes de eficācia alimentar e protēica superioresao das fêmeas, como jā tivemos oportunidade de descrever tambēm em rela ção aos îndices anteriores.

Portanto os resultados obtidos para CEA e CEP, cont 1 dos nas Tabelas 38 e 39 e Figuras 23 a 25 e 29 a 31 , de uma geração para outra, fixando o indice de $100 \%$ para a la. geração, demonstraram que ao nîvel protēico de $25 \%$ os grupos controle de caseīna, apresentaram uma eficiēncia alimentar e protēica praticamente da mesma ordem para a 2 a. geração de animais machos, sendo entretanto ligeiramente inferiores para as fêmeas. Entretanto, na $3 a$. geração os resultados mostraram-se semelhan tes, tanto para machos como para fêmeas.

Quanto ao nīvel protēico de $10 \%$ na ração, Tabelas 40 e 41 e Figuras 26 a 28 e de 32 a 34 , tambēm não houve diferenças acentuadas de uma geração para outra, principalmente no primeiro mês, onde se verificou o maior desenvolvimento do ani ma 1, como tambēm jā era esperado, pois em relação ao rato, a fase do desmame atē os 60 dias, $\bar{e}$ onde se processa o maior desenvolvimento.

A fim de verificarmos a evolução dos animais, nos diferentes períodos, dentro do mesmo grupo, tambēm fixamos o īndice de $100 \%$ para o desenvolvimento no 10 mês e calculamos os percentuais obtidos em relação a este, para o 20 e 30 mês.

os resultados mostraram, que de uma forma geral, os grupos controle apresentaram um declīneo para o 20 mês em rela 
TABELA 38 - Médias e desvio padrão do coeficiente de eficácia alimentar (CEA), de 3 gerações de animais, alimen tados com ração controle de caseina e experimen tal de biomassa, ao nível protēico de $25 \%$, nos di ferentes períodos da experiência. (COZZOLINo, 1982)

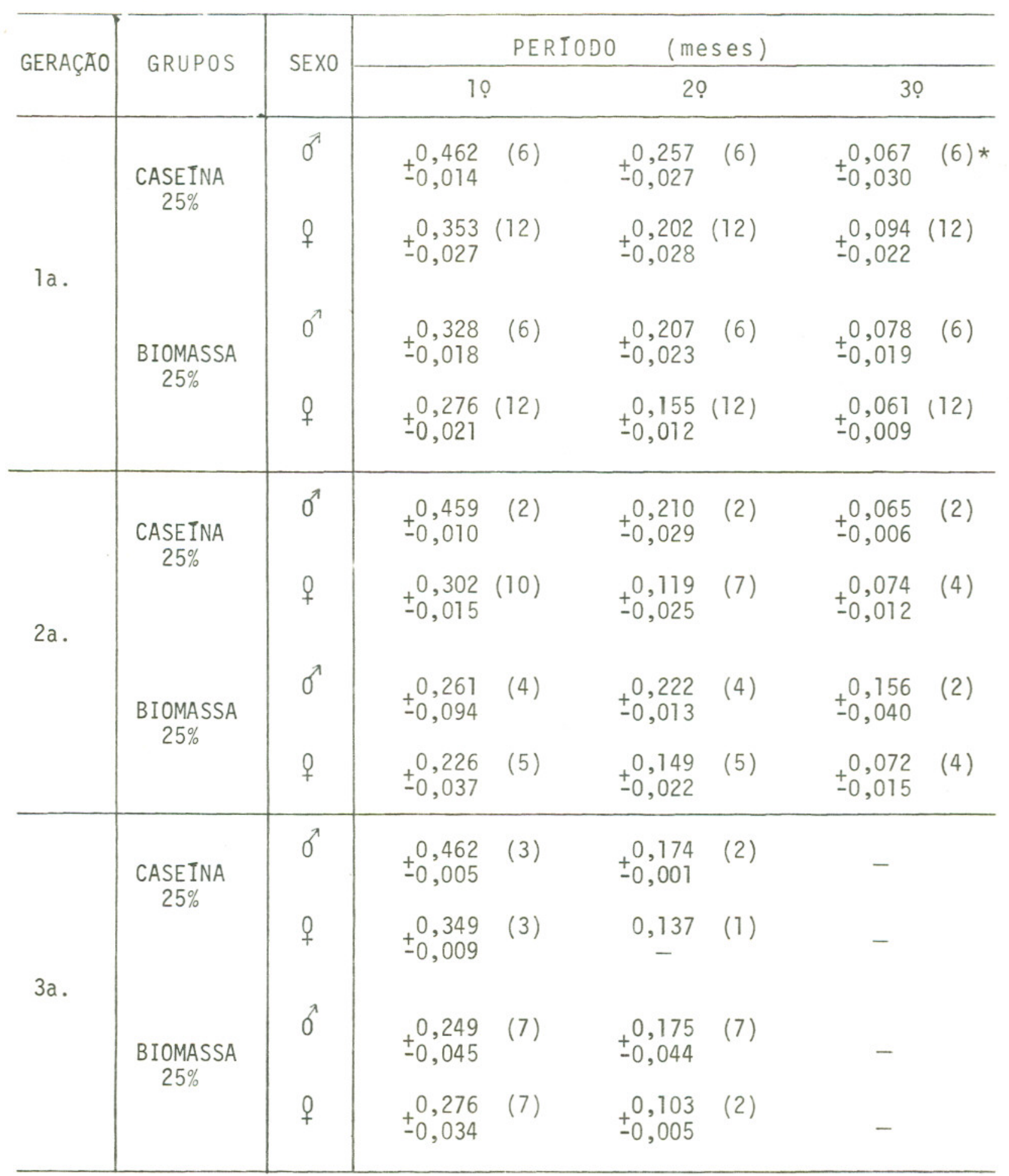

*Entre parenteses o nūmero de animais. 
TABELA 39 - Médias e desvio padräo do coeficiente de eficācia protéica (CEP), de 3 gerações de animais, alimenta dos com ração controle de caseina e experimental de biomassa, ao nīvel protéico de $25 \%$, nos dife rentes períodos da experiência. (COzzolino, 1982).

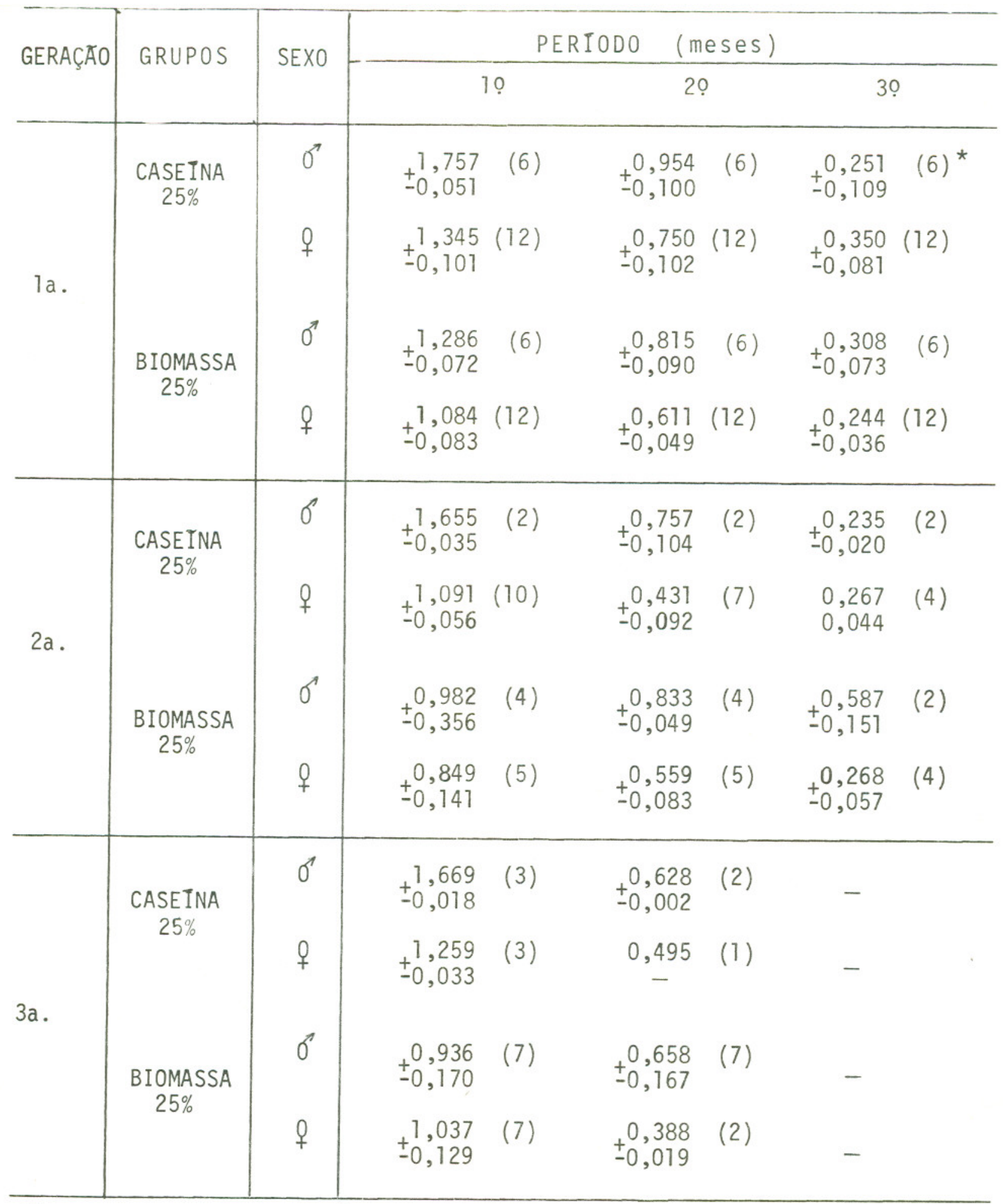

*Entre parenteses o nümero de animais. 


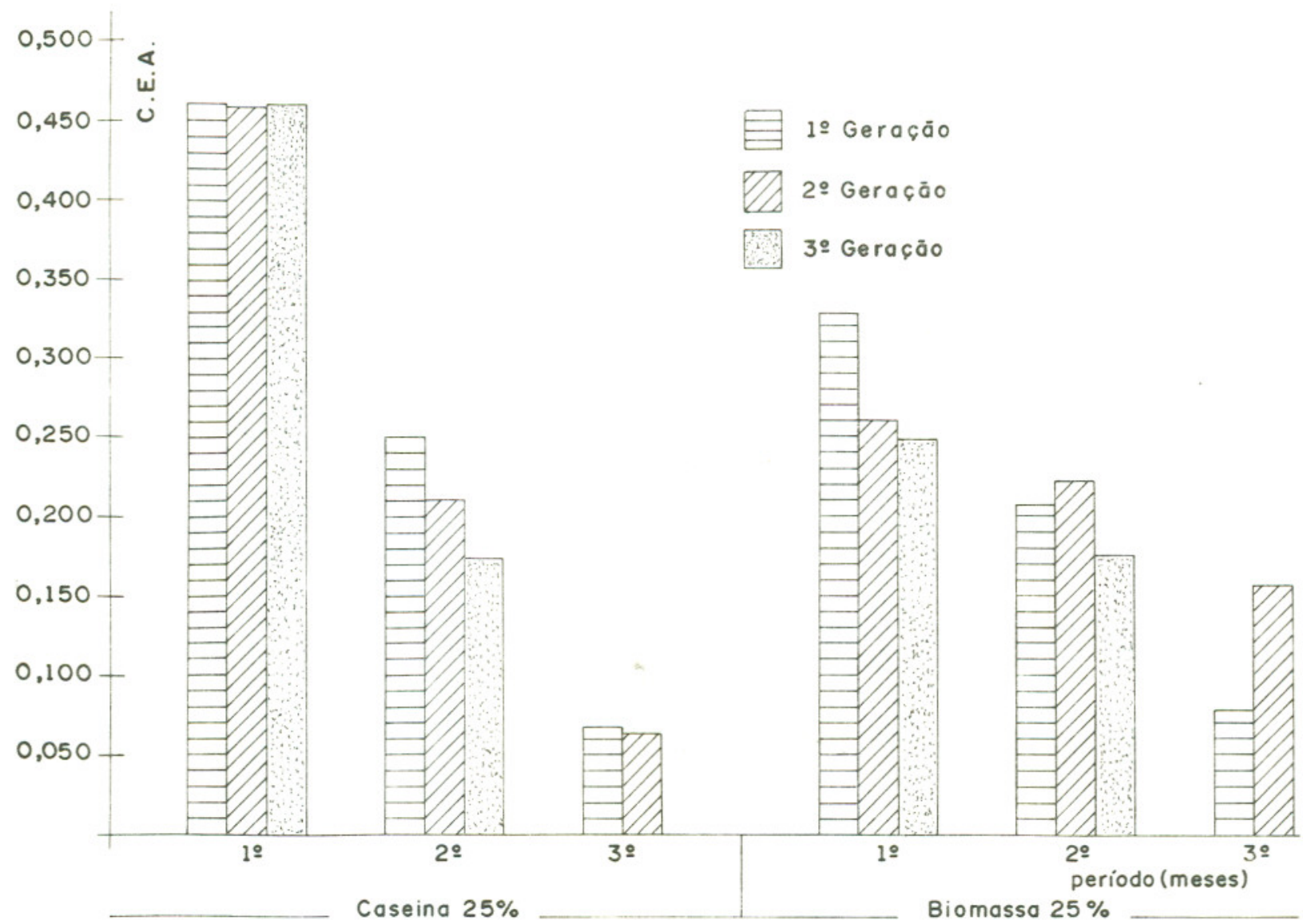

Fig.23-Coeficiente de Eficácia Alimentar (C.E.A) de 3 geraçōes de ratos machos, alimentados com raçōes de Caseína e Biomassa, a nível protéico de $25 \%$.

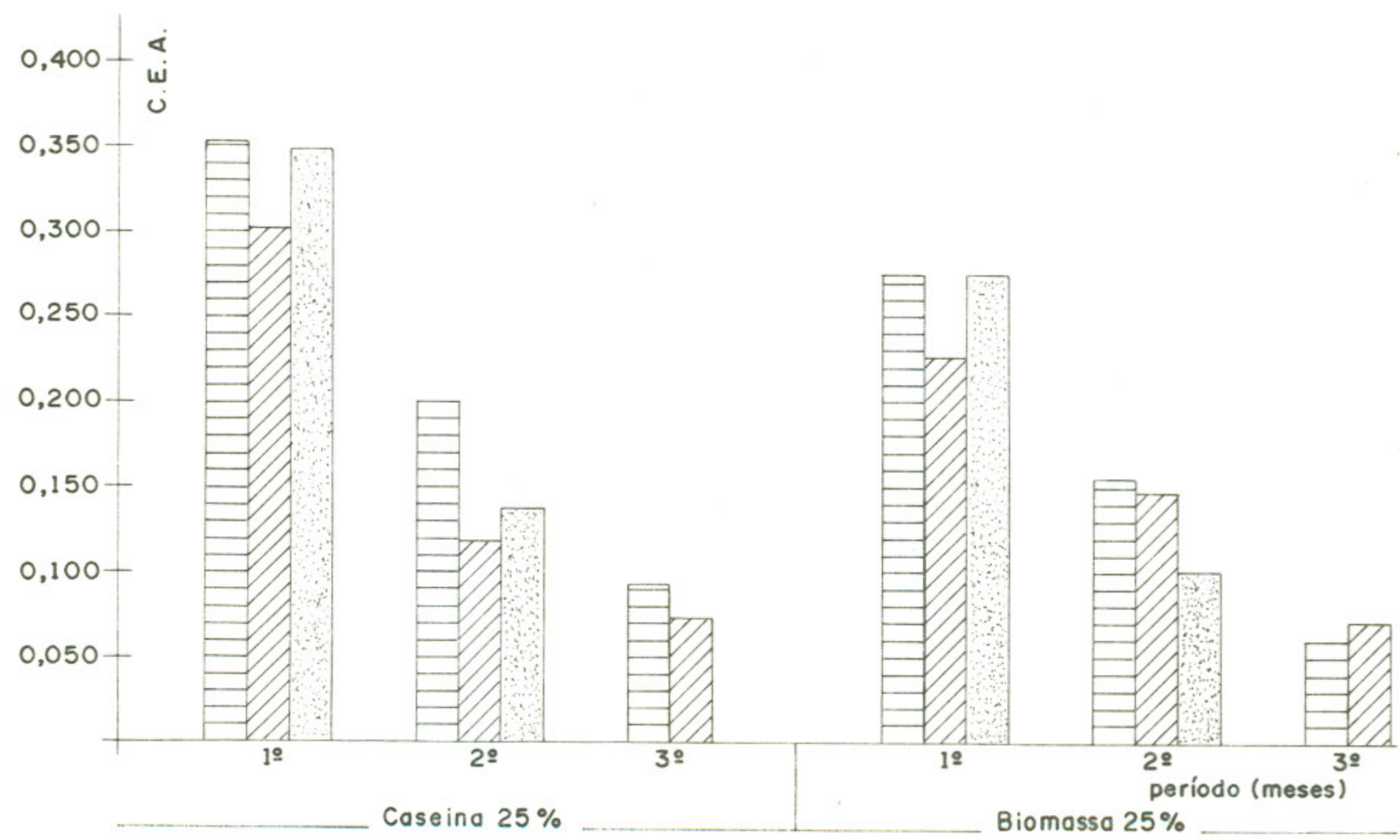

Fig.24 - Coeficiente de Eficácia Alimentar (C.E.A) de 3 geraçōes de ratos femeas, alimentados com raçōes de Caseína e Biomassa, ao nível protéico de $25 \%$. 

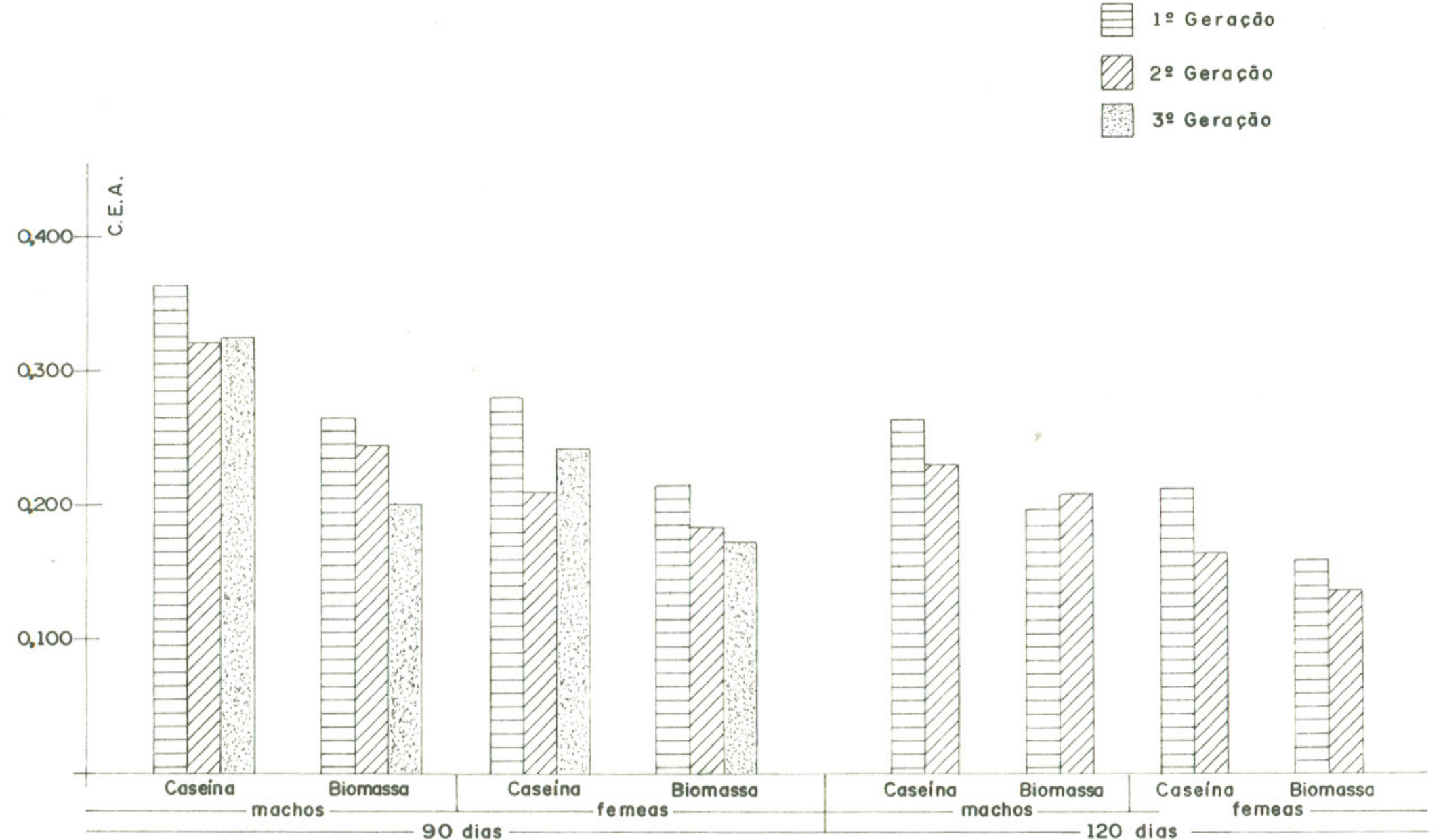

Fig.25 - Coeficiente de Eficácia Alimentar (C.E.A.), do desmame até 90 e 120 dias, de 3 geraçōes de animais alimentados com racóes de Coseína e Biomassa, ao nivel protéico de $25 \%$. 

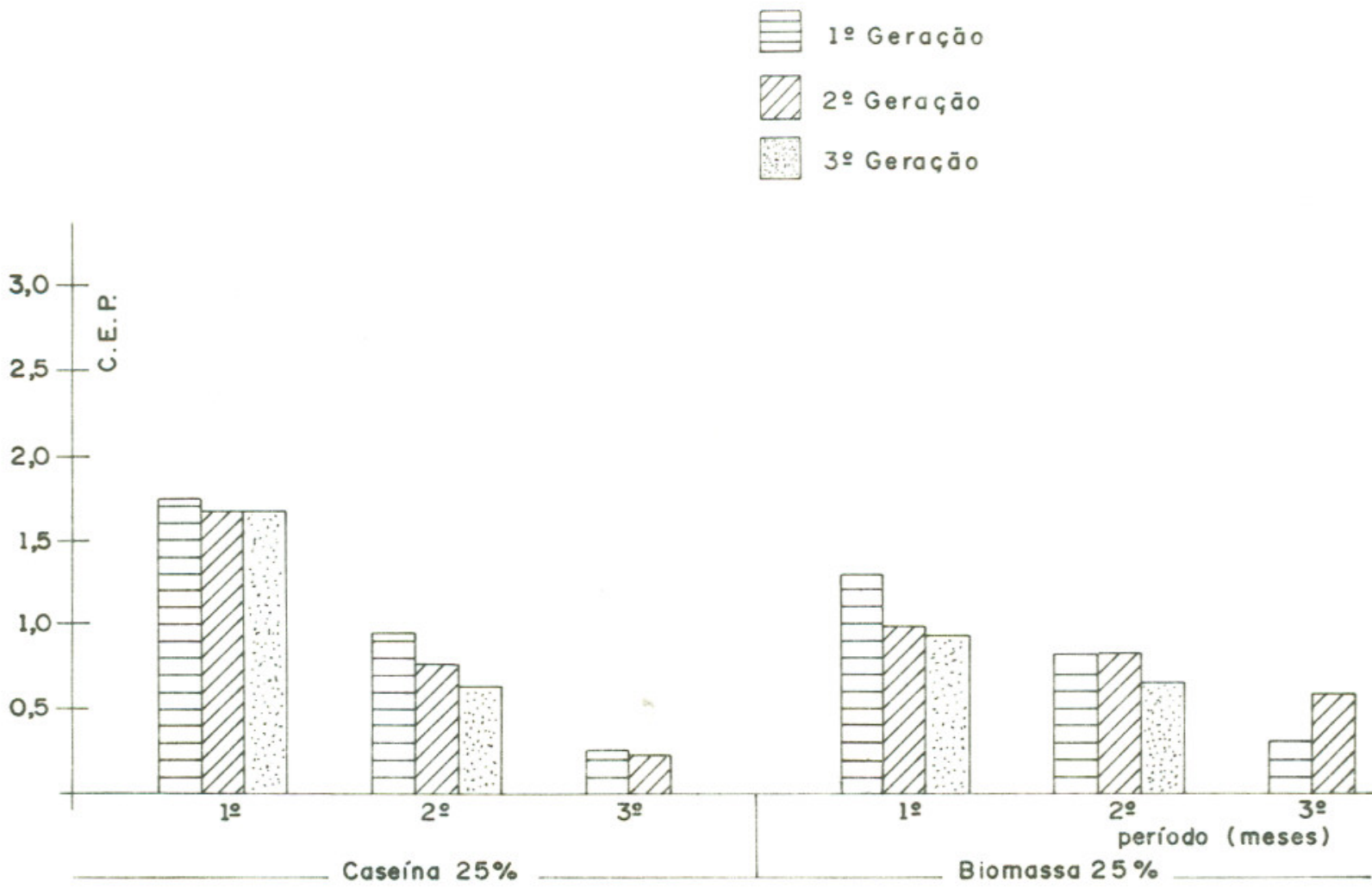

Fig.29- Coeficiente de Eficácia Protéica (C.E.P.) de 3 geracōes de ratos machos, alimentados com raçōes de Caseína e Biomassa, ao nivel protéico de $25 \%$
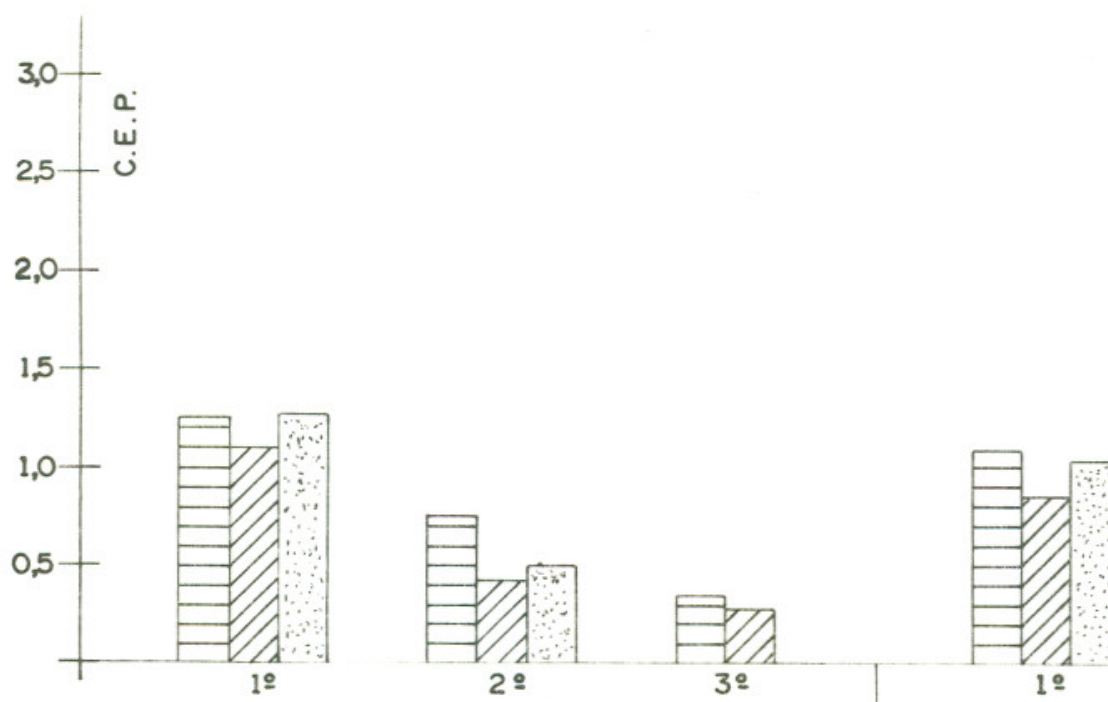

10

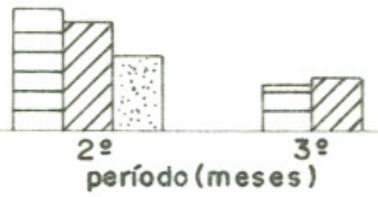

Caseina $25 \%$ Biomassa $25 \%$

Fig.30 - Coeficiente de Eficácia Protéica (C.E.P.) de 3 geracōes de ratos femeas, alimentados com raçōes de Caseína e Biomassa, ao nível protéico de $25 \%$. 

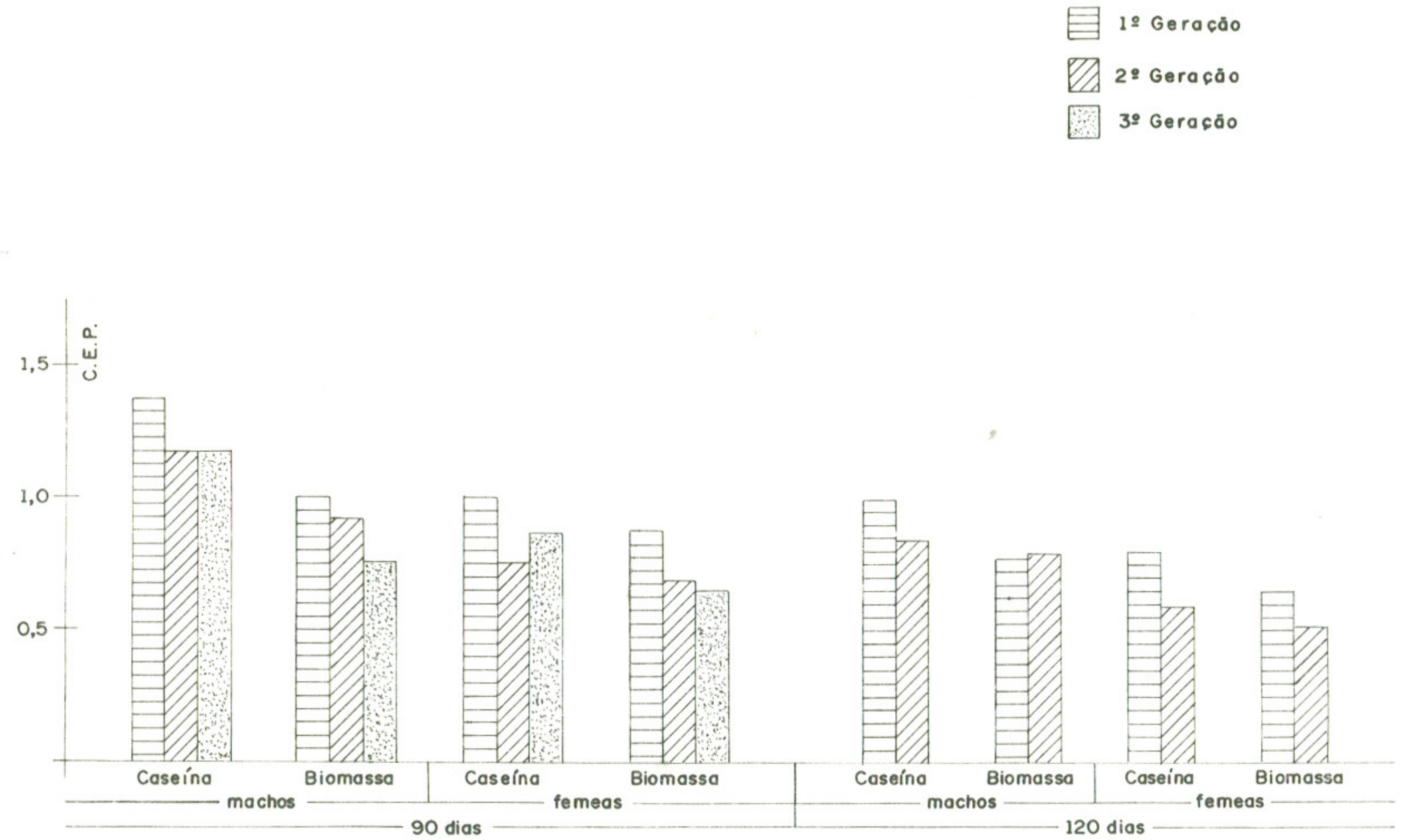

Fig.31 - Coeficiente de Eficácia Protéica (C.EP.), do desmame até 90 e 120 dias, de 3 geraçōes de animais alimentados com raçōes de Caseína Biomassa, ao nivel protéico de $25 \%$. 
TABELA 40 - Médias e desvio padrão do coeficiente de eficácia alimentar (CEA), de 3 gerações de animais, alimenta dos com ração controle de caseĩna e experimental de biomassa, ao nỉvel protéico de $10 \%$, nos diferentes períodos da experiência. (COzzolino, 1982).

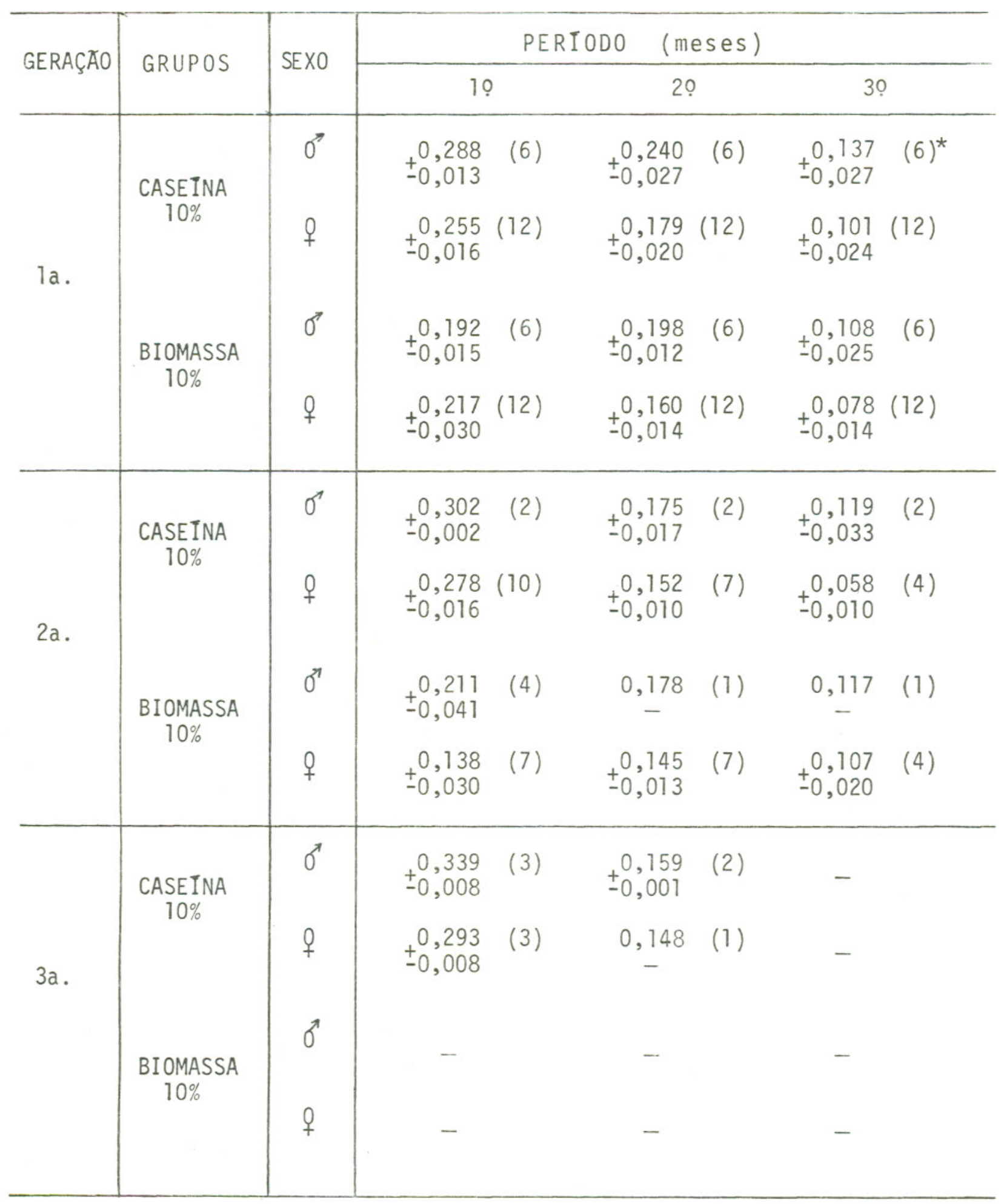

*Entre parenteses o número de animais. 
TABELA 41 - Médias e desvio padrão do coeficiente de eficácia protéica (CEP), de 3 gerações de animais, alimenta dos com ração controle de caseĩna e experimental de biomassa, ao nîvel protéico de $10 \%$, nos diferentes periodos da experiência. (COZzolino, 1982).

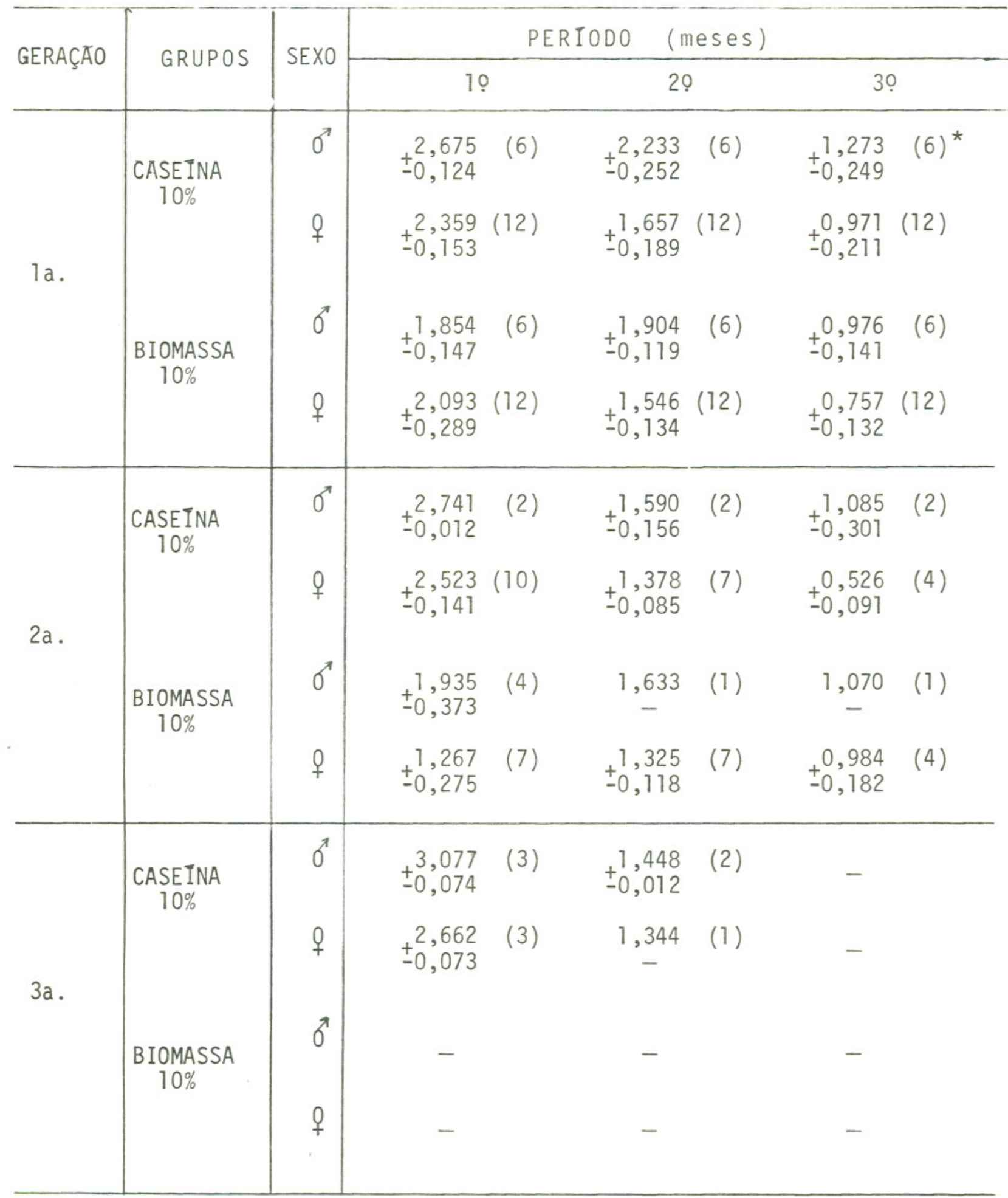

*Entre parenteses o nümero de animais. 


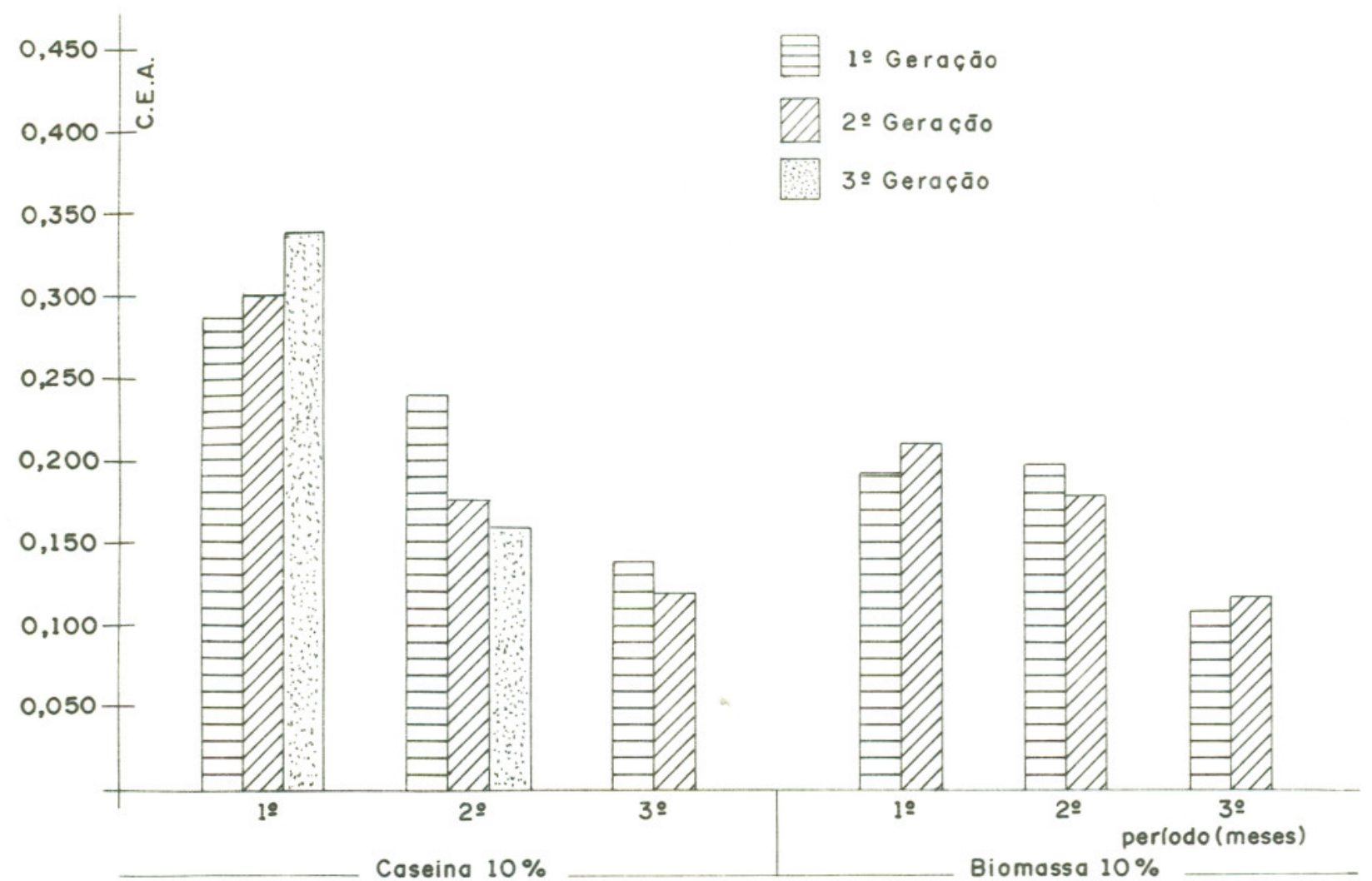

Fig. 26 - Coeficiente de Eficácia Alimentar (C.E.A.) de 3 geraçóes de ratos machos, alimentados com raçōes de Caseína e Biomassa, ao nível protéico de $10 \%$.

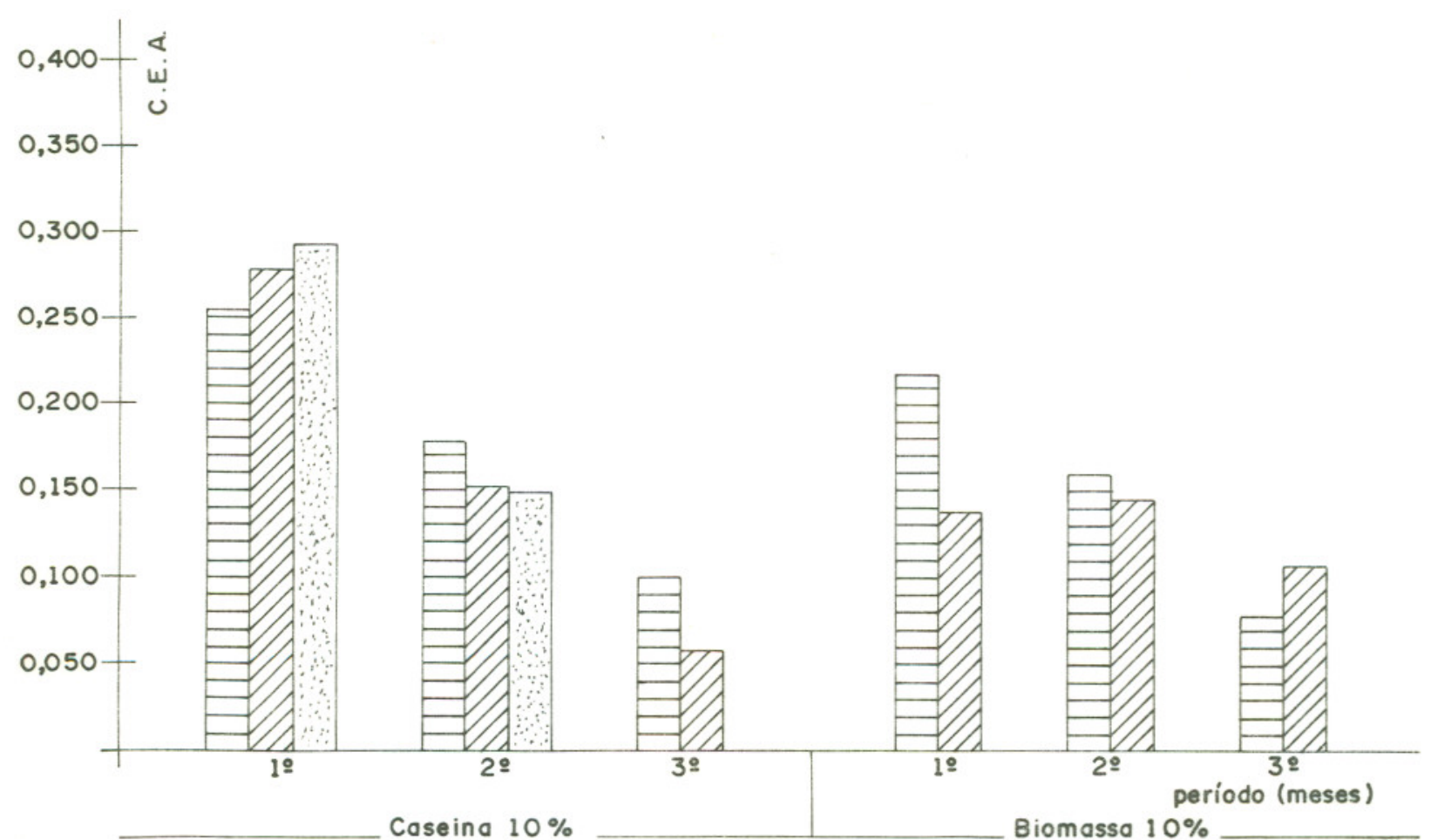

Fig.27 - Coeficiente de Eficácia Alimentar (C.E.A.) de 3 geraçōes de ratos femeas, alimentados com raçōes de Caseina e Biomassa, ao nível protéico de $10 \%$. 

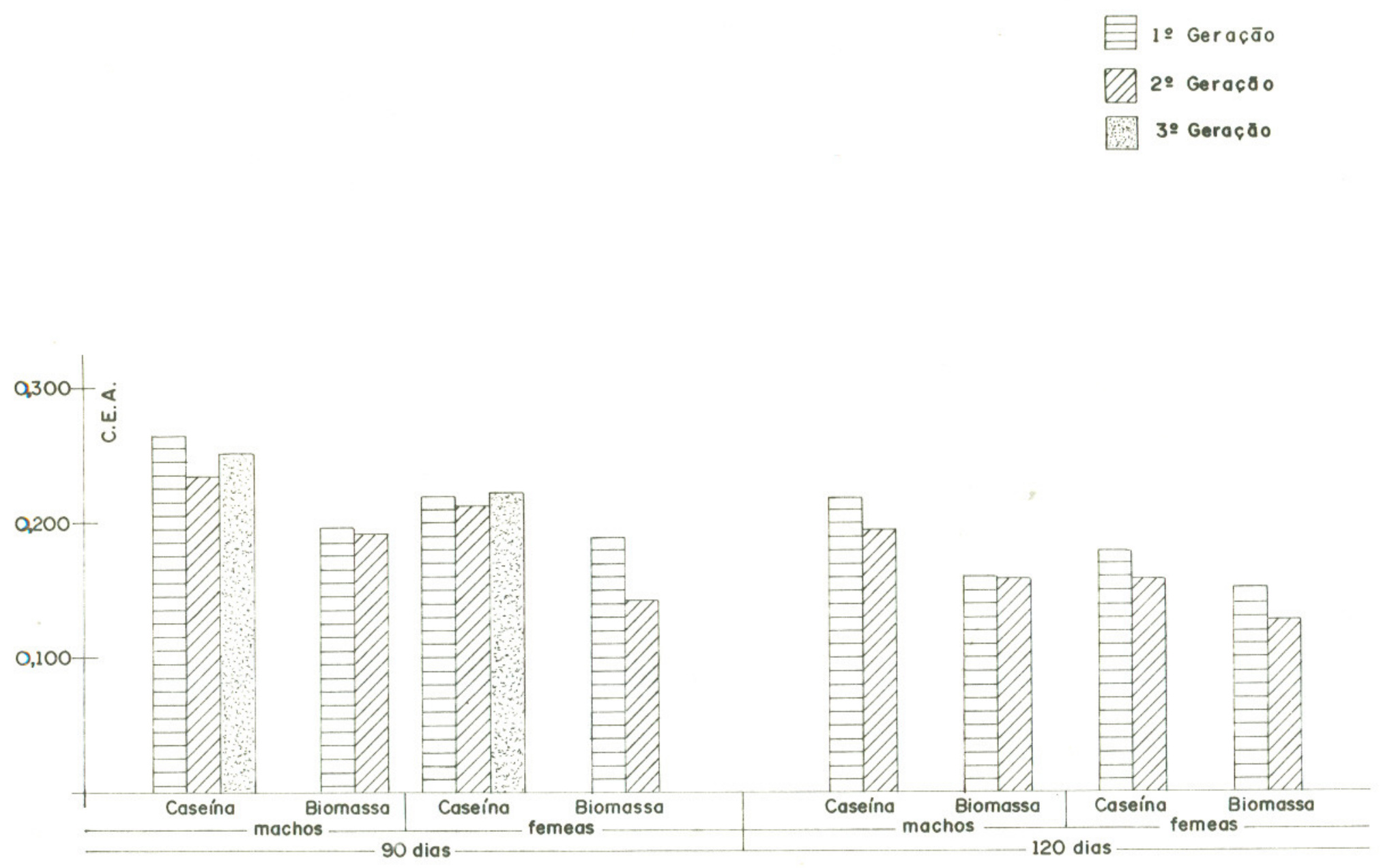

Fig. 28 - Coeficiente de Eficácia Alimentar (C.E.A.), do desmame até 90 e 120 dias, de 3 geraçōes de animais alimentados com raçoes de Caseína e Biomassa, ao nivel protéico de $10 \%$. 


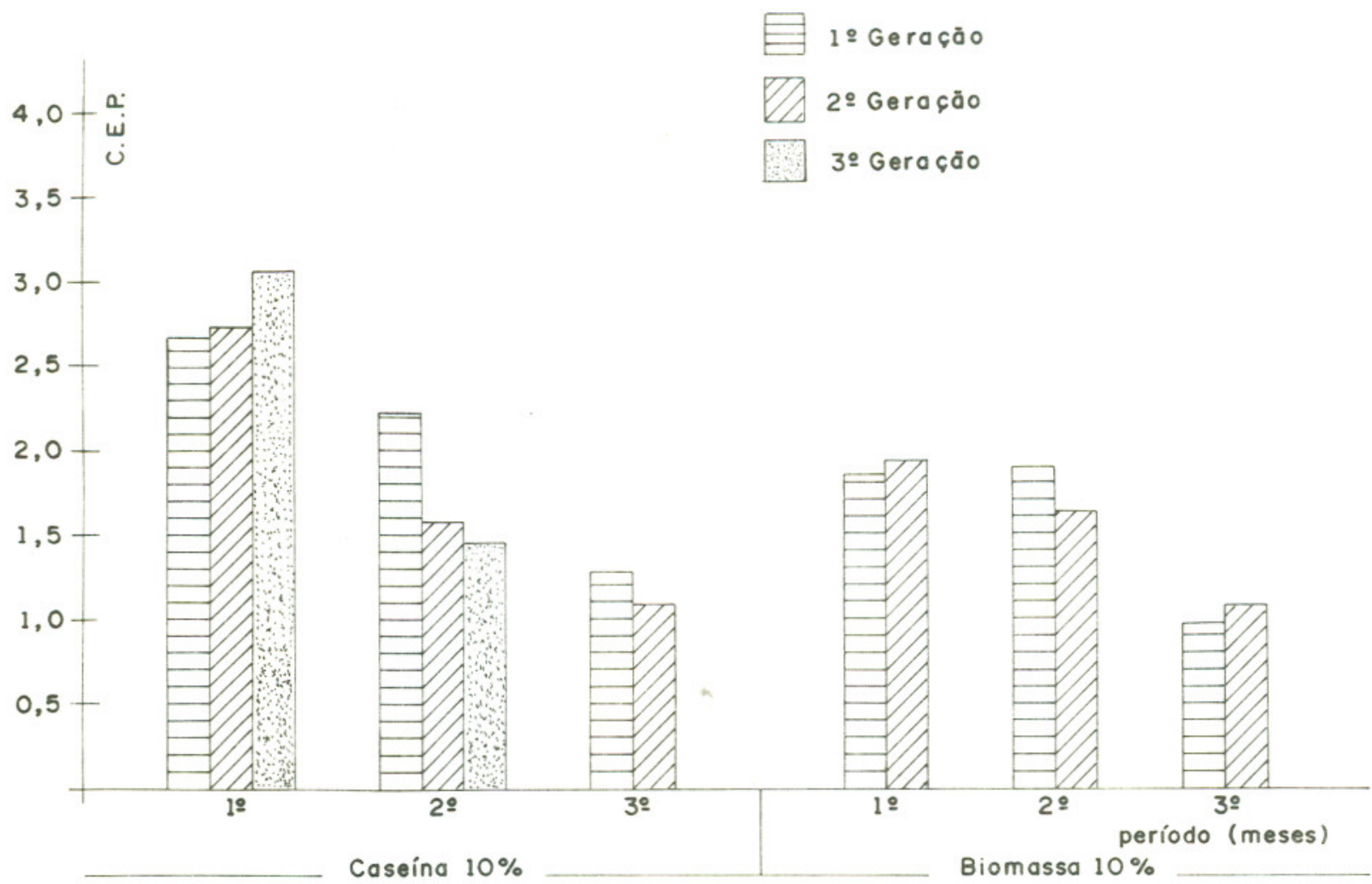

Fig.32 - Coeficiente de Eficácia Protéica (C.E.P.) de 3 geraçōes de ratos machos, alimentados com raçōes de Caseína e Biomassa, ao nível protéico de $10 \%$.

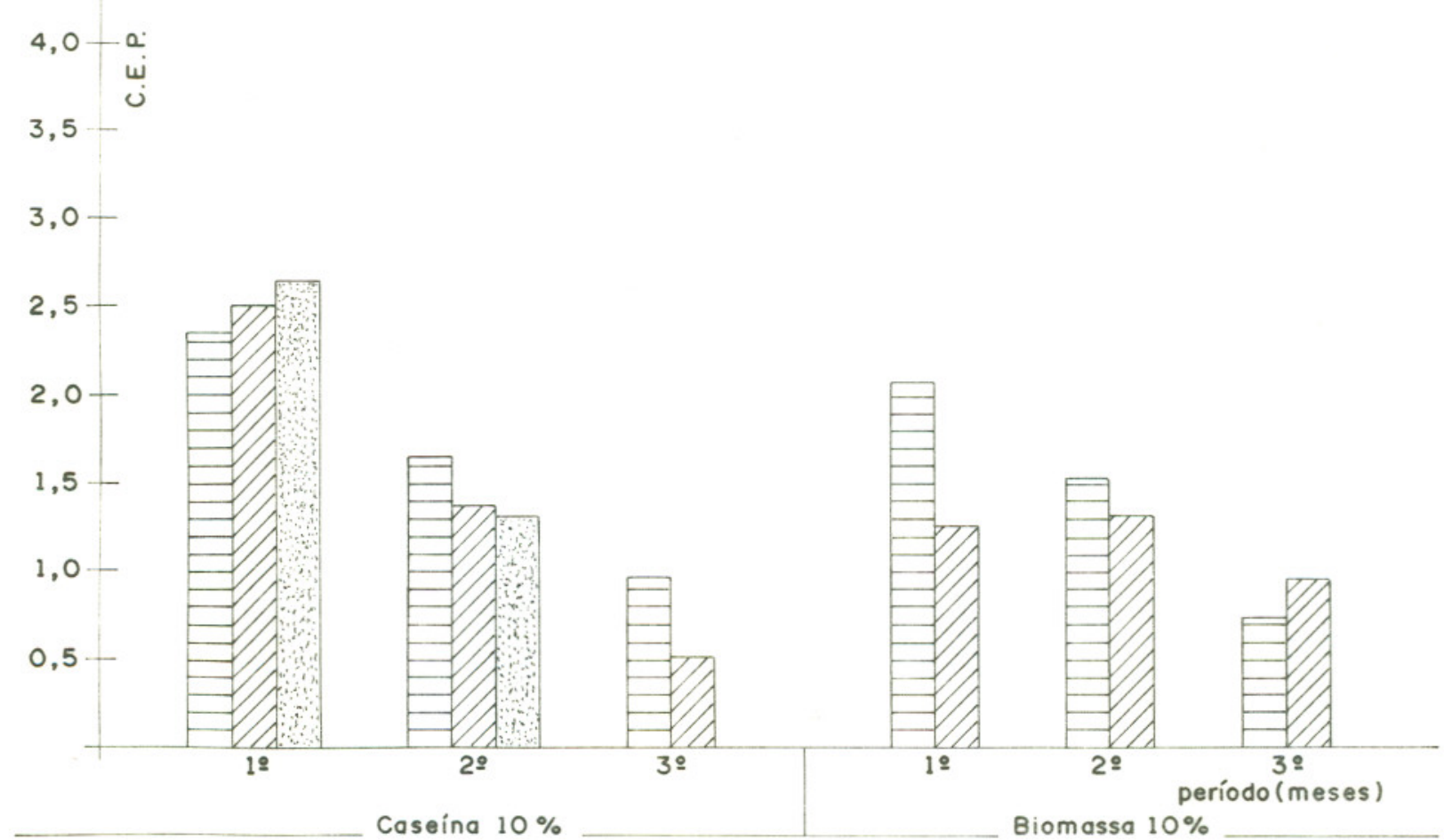

Fig.33 - Coeficiente de Eficócia Proteîca (C.E.P.) de 3 geraçōes de ratos femeas, alimentados com raçōes de Caseína e Biomassa, ao nível protéico de $10 \%$. 

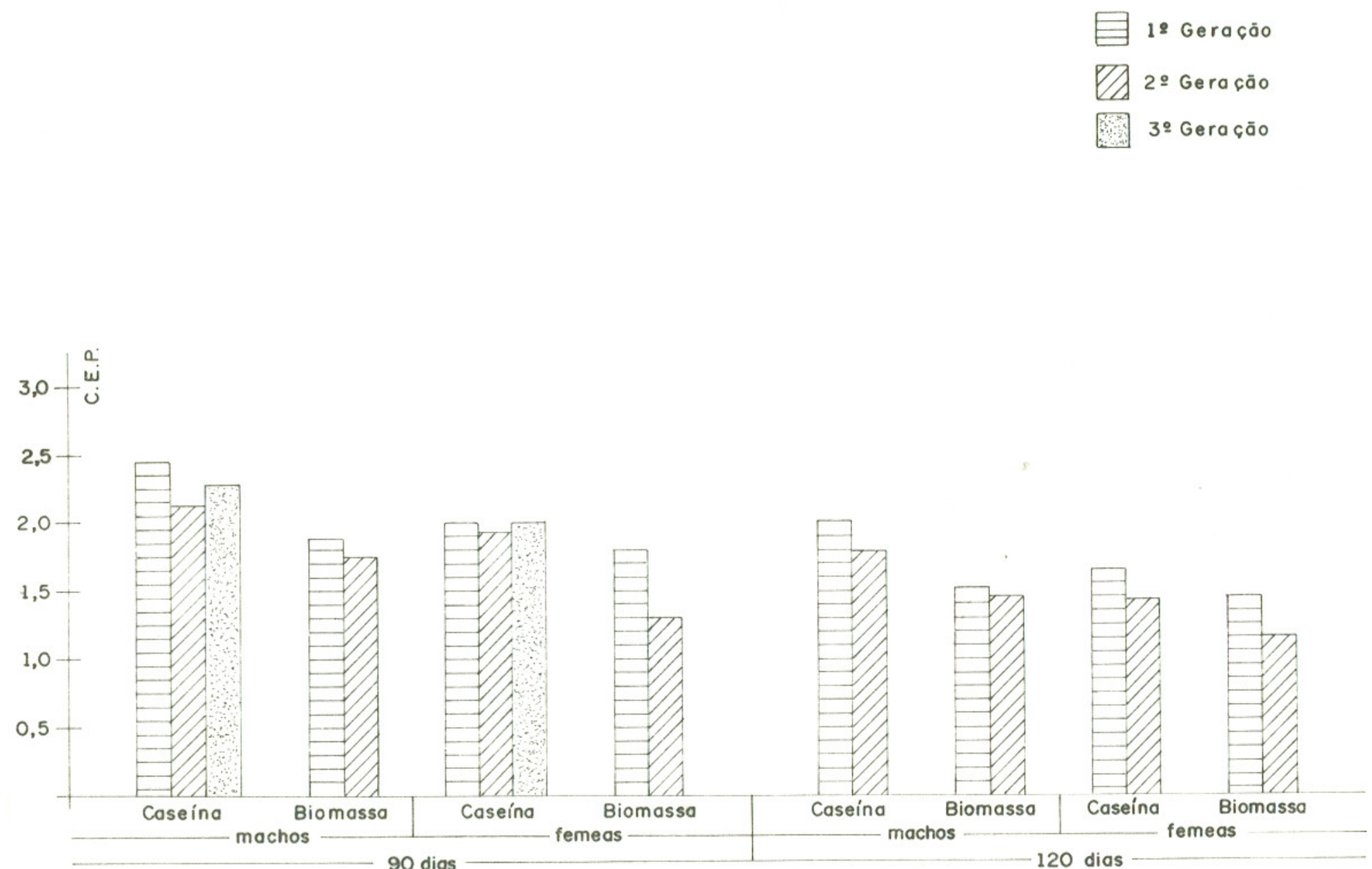

Fig.34- Coeficiente de Eficácia Protéica (C.E.P.), do desmame até 90 e 120 dias, de 3 geracōes de animais alimentados com raçöes de Caseína e Biomassa, ao nível protéico de $10 \%$ 
ção ao 1ọ, acentuando-se ainda mais no 30 mês, tanto para machos como para fêmeas, nas 3 gerações estudadas.

Em relação aos grupos experimentais de biomassa, observamos que os resultados obtidos foram diferentes daqueles observados para os grupos controle de caseina. Assim, ao nïvel protēico de $25 \%$ na ração, verificamos que nas 2 as. e 3 as. gerações, os îndices obtidos principalmente no primeiro mês fo ram inferiores aos obtidos na la. geração, entretanto novamente mostrando um aumento da eficiência alimentar e protëica aos 20 e 30 meses, indicando uma adaptação do animal ao tipo de ra ção oferecida, atravēs do controle entre ingestão e aproveitamento da mesma.

Quanto aos grupos de animais submetidos à mesma ração experimental, porēm ao nīvel protēico de $10 \%$, verificamos que os animais machos apresentaram na 2 a. geração praticamente o mesmo comportamento observado em relação à la. geração, porēm o grupo de fêmeas mostrou nīveis inferiores em relação ao primeiro mês, aumentando gradativamente em relação ao 20 e 30 meses, da mesma forma observada para os demais grupos experi mentais de biomassa ao nîvel protēico de $25 \%$.

A verificação evolutiva dentro do mesmo grupo, tambēm fixando o îndice de $100 \%$ para o 10 mês, mostrou que em rela ção à la. geração, os resultados foram semelhantes aos obtidos para os grupos controle de caseīna em relação ao nīvel protēi co de $25 \%$, pois observamos uma diminuição da eficiência alimen tar e protēica no 20 mês em relaçäo ao 10 mês, acentuando-se ainda maiss no 30 mês. Entretanto, tal fato não foi verifica- 
do para os grupos de animais machos, ao nïvel protēico de $10 \%$ na ração, onde observamos indices de CEA e CEP superiores para os 20 e 30 meses de experiência em relação aos demais grupos, não ocorrendo o mesmo em relação às femeas, que se comportaram de acordo com os grupos anteriores.

Em relação à 2a. geração, os grupos de biomassa, mos traram da mesma forma anteriormente descrita para o grupo de animais machos, alimentados ao nīvel protēico de $10 \%$ na la. geração, uma continuidade de eficiência alimentar e protēica nos meses subsequentes, portanto demonstrando mais uma vez, a im portância da adaptação do animal em fenômenos de desnutrição.

A comparação entre os grupos de caseĩna e de biomassa ao nīvel protēico de $25 \%$ na 1 a. geração, em relação ao CEA e CEP, como indicadores do valor biolögico da biomassa em rela ção à caseîna, mostrou-se inferior para os grupos de biomassa, sendo que para os machos, os valores comparativos em relação ao CEA e CEP, respectivamente, foram: $71,0 \%$ e $73,2 \%$ no 10 mês, $80,5 \%$ e $85,4 \%$ no 20 mês e $116,4 \%$ e $122,7 \%$ no 30 mês; em rela ção às fêmeas foram $78,2 \%$ e $80,6 \%$ no 1 ọ mês, $76,7 \%$ e $81,5 \%$ no 20 mês e $64,9 \%$ e $69,7 \%$ no 30 mês. Verificamos, portanto, que - grupo de animais machos, alimentados com ração de biomassa ao nîvel protēico de $25 \%$, mantiveram um desenvolvimento crescente atē o 30 mês, suplantando inclusive os valores observados em relação à caseĩna no ūltimo mês, enquanto que as fêmeas submetidas ao mesmo tratamento, apresentaram um desenvolvimento mais acentuado no 10 mês, entretanto inferiores aos observa dos para o grupo controle de caseĩna. 
A mesma comparação anterior para os grupos controle de caseína e experimental de biomassa, ao nīvel protēico de 10\% na ração da la. geração, apresentaram os seguintes valores: em relação aos machos, os indices de CEA e CEP foram res pectivamente $66,7 \%$ e $69,3 \%$ no 10 mês, $82,5 \%$ e $85,3 \%$ no 20 mês e $78,8 \%$ e $76,7 \%$ no 30 mês, e em relação às fêmeas, $85,1 \%$ e $88,7 \%$ no 10 mês, $89,4 \%$ e $93,3 \%$ no 20 mês e $77,2 \%$ e $78,0 \%$ no 30 mês. Portanto, novamente verificamos que os resultados fo ram inferiores para a biomassa, durante todo período experi mental da 1a. geração.

Em relação à segunda geração, verificamos que ao nị vel protēico de $25 \%$, tambëm considerando-se os valores obti dos para o grupo controle de caseina como $100 \%$, os resultados obtidos para CEA e CEP respectivamente, para o grupo de animais machos foram: $56,9 \%$ e $59,3 \%$ no 10 mês, $105,7 \%$ e $110,0 \%$ no 20 mês, $240,0 \%$ e $249,8 \%$ no 30 mês, em relacão às fêmeas, $74,8 \%$ e $77,8 \%$ no 19 mês, $125,2 \%$ e $129,7 \%$ no 20 mês e $97,3 \%$ e $100,4 \%$ no 30 mês. Portanto, mais uma vez, os animais obtiveram indices inferiores ao dos grupos de caseína no 10 mês, re cuperando-se em seguida atê 030 mês.

Ao nîvel protēico de $10 \%$ na ração, os resultados fó ram para os machos, $69,9 \%$ e $70,6 \%$ no 10 mês, $101,7 \%$ e 102,7\% no 20 mês, $98,3 \%$ e $98,6 \%$ no 30 mês, e em relação às fêmeas $49,6 \%$ e $50,2 \%$ no 10 mês, $95,4 \%$ e $96,2 \%$ no 20 mês e $184,5 \%$ e $187,1 \%$ no 30 mês, portanto o mesmo fato se repetiu.

$\mathrm{Na} 3 \mathrm{a}$. geração as mesmas comparações para os grupos ao nīvel protēico de $25 \%$, mostram os seguintes valores para 
os grupos de biomassa em relação aos da caseĩna: para os gru pos de machos $53,9 \%$ e $56,1 \%$ no 10 mês, $100,6 \%$ e $104,8 \%$ no 20 mês, e em relação às fêmeas $79,1 \%$ e $82,4 \%$ no 10 mês e $75,2 \%$ e $78,4 \%$ no 20 mês.

Portanto, analisando-se estes resultados verificamos que os grupos controle apresentaram o desenvolvimento esperado em relação às gerações, bem como em relação à sua evolução no periodo estudado (120 dias), enquanto os grupos de biomassa apresentaram resultados diferentes, mantendo seu desenvolvimento de forma equilibrada atë o 30 mês, demonstrando uma adaptação do organismo animal em relação ao tratamento utilizado.

As comparações em relação ao CEA e CEP das rações ex perimentais e controle, mostraram-se sempre inferiores para as experimentais, fato jā bastante discutido devido aos inūmeros fatôres apresentados que influiram em tais resultados. 


\section{7 - CONSIDERAÇOES FINAIS}

Como pode ser observado atravēs da anālise dos resul tados, o comportamento biológico dos animais submetidos aos tra tamentos de caseina como fonte protëica padrão e biomassa como fonte protēica experimental, mostrou-se diferente em rela ção ao desenvolvimento dos animais, sendo que os grupos de caseina mostraram-se superiores aos de biomassa.

Nossos dados estão em concordāncia com o de outros a $\underline{u}$ tores, que tambēm demonstraram que esta fonte protéica, possue valor biolögico inferior às fontes consideradas padrões (19) $(31)(39)(47)(48)(73)(75)(78)(86)(106) 116)$.

Houve uma diminuição do valor biolögico nas segunda e terceira gerações dos grupos de biomassa em relação à primeira geração, chegando inclusive a uma interrupção no caso de bio massa ao nível de $10 \%$ de proteỉna na ração.

Este fato embora bastante discutido em nosso traba1ho, pode ser uma vez mais explicado, devido ao fato da proteí na da biomassa por nōs estudada, ter apresentado um teor de ni trogênio não protēico da ordem de $1,6 \mathrm{~g}$ em 100 gramas de biomas sa, calculado atravēs do aminograma, onde obtivemos apenas 40 gramas de proteina em 100 gramas de biomassa. Portanto, na 
na realidade teríamos apenas $8 \%$ de proteinna na ração.

os problemas observados em relação à reprodução, poderiam numa anālise final, serem atribuidos a um retardo no de senvolvimento do animal, entretanto não permitem conclusões de finitivas.

Quanto à anālise dos örgãos dos animais, procuramos ve rificar possîveis alterações nestes örgãos, decorrentes do tipo de tratamento, uma vez que värios trabalhos $(46)(54)(66)$, demonstraram problemas toxicolōgicos principalmente em relação ao figado e rins. Entretanto, como o nümero de animais obti dos na 2 a. e $3 a$. geração foì reduzido, os resultados não trouxeram subsĩdios para conclusões definitivas, assim eles não constarão do presente trabalho, ficando ainda sujeitos a anāl ses posteriores mais detalhadas.

Por outro lado, os resultados não sugerem problemas de ordem toxicolögica, pois não observamos anormalidades quanto a excesso de gordura hepātica, bem como os teores de prote nas totais nos ōrgãos tambēm foram semelhantes em relação aos grupos controle e experimentais.

As anālises histolōgicas, tambēm mostraram-se normais, mesmo ao nîvel protēico de $25 \%$, considerado al to para esta fonte alimentar.

Por outro lado, como jā evidenciamos na introdução deste trabalho, existem normas para utilização desta fonte protëica que devem ser tomadas como base para qualquer programa que venha a ser estabelecido. Assim segundo o P.A.G. ${ }^{\star}(6)(33)$

\footnotetext{
*Protein advisory group.
} 
(51)(52) dependendo da utilização desta fonte protēica, se para al imentaçäo humana ou animal, värios cuidados devem ser respei tados, principalmente se för para alimentação humana. Sabemos que os teores elevados de ācidos nucleicos causam problemas ao ser humano, entretanto não foram estudados neste trabalho, uma vez que o rato não $\overline{\mathrm{e}}$ o animal adequado para este estudo, pois podem metabolizar o ācido ürico atē alantoỉna e desta forma eliminā-lo sem problemas de acumulo.

Como potencial protēico, esta biomassa apresentou fa tores limitantes, que foram observados desde a fase inicial do experimento, ou seja na lactação dos animais, e durante todo o desenvolvimento, acentuando-se na gestação, tanto que os animais da 2a. geração, apresentaram um desenvolvimento mais lento em relação ao padrão, podendo-se observar os ratos da mesma idade nas fotos 1 e 2, 15 dias apōs o nascimento e na foto 3 , na ēpoca do desmame.

Estes animais na fase adulta puderam se recuperar, em bora os resultados tenham sido inferiores aos da caseína.

Pode-se observar tambēm que alguns animais do grupo de biomassa apresentaram manchas brancas no olho (foto 4), levando-nos a pensar em deficiēncia de vitamina A. Sabe-se que esta vitamina é transportada ligada a proteīna, em em casos de desnutrição, a deficiência desta proteīna poderia explicar a deficiēncia ao nīvel de visão, provocando tais anormalidades, mesmo encontrando-se presente na ração. 


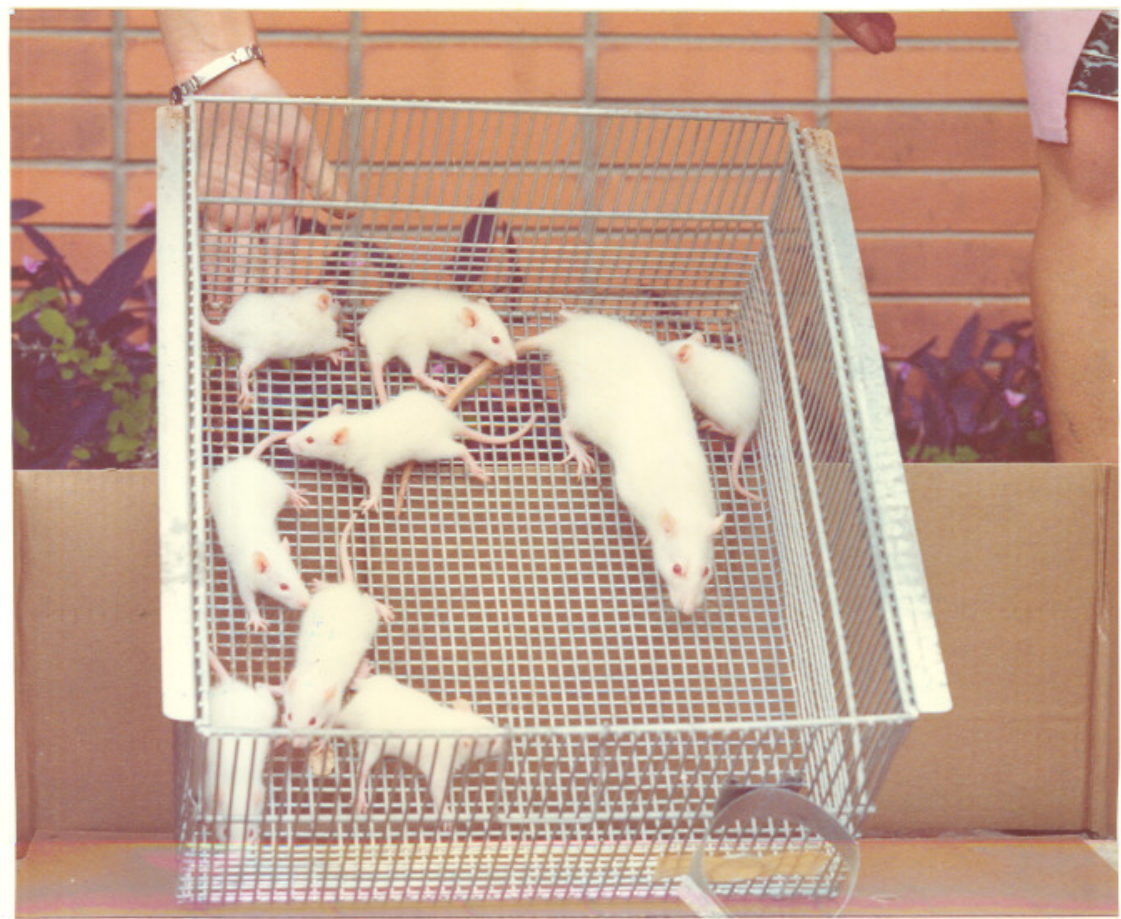

Foto 1 - Animais do grupo controle de caseīna, 15 dias apōs o nascimento.

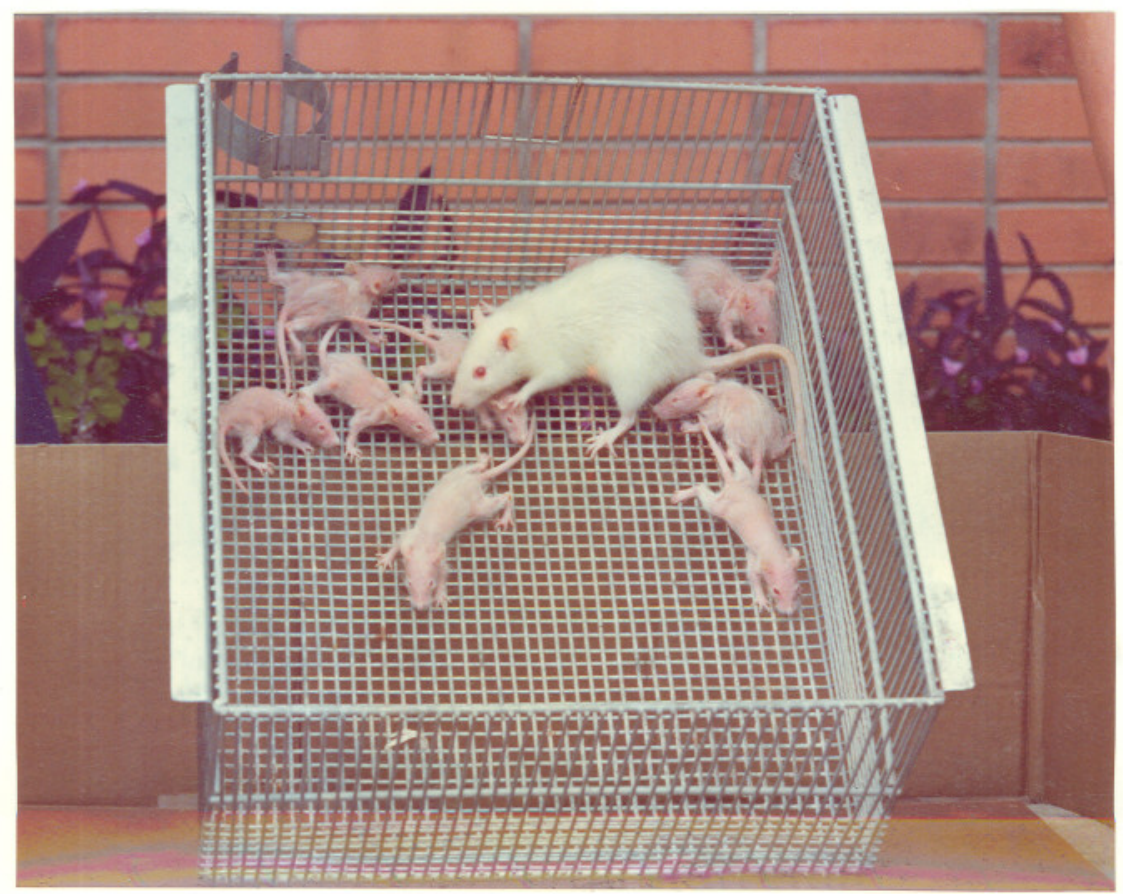

Foto 2 - Anjmais do grupo experimental de biomassa, 15 dias apös o nascimento. 


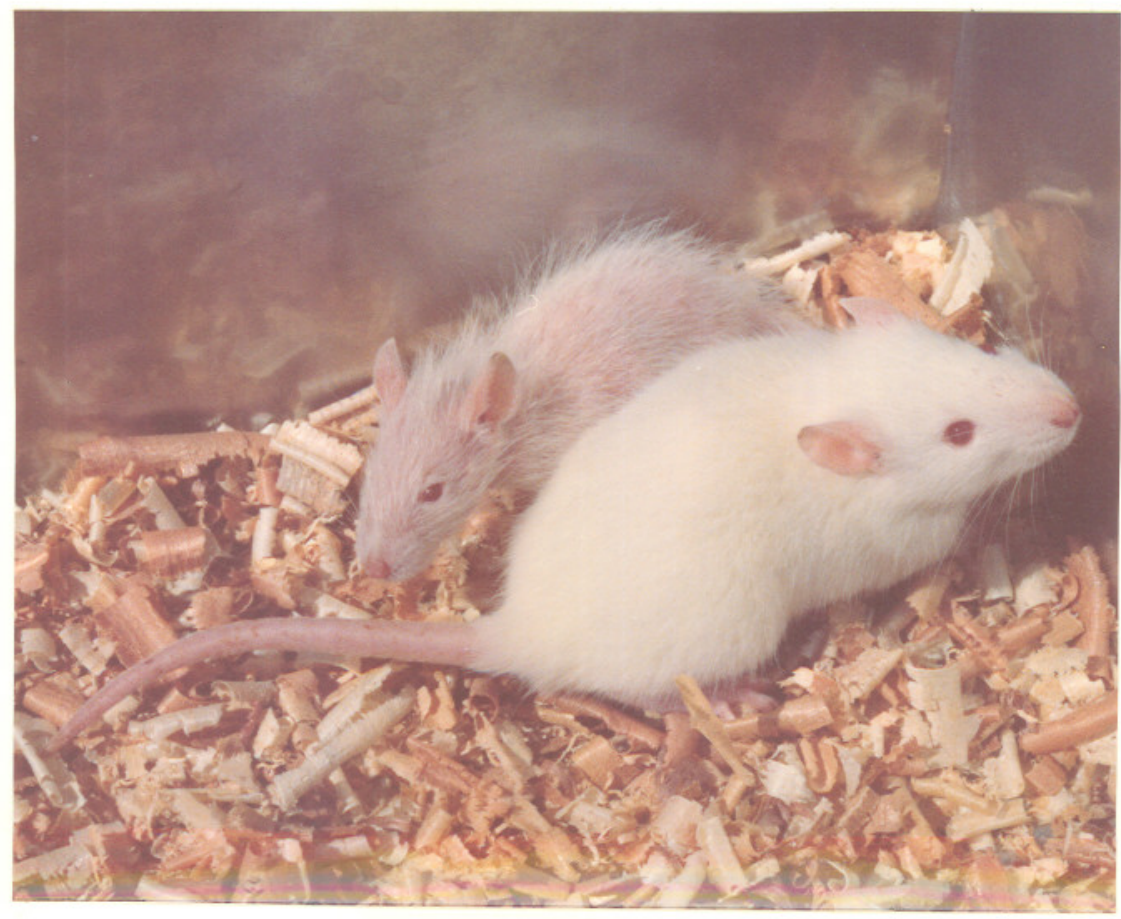

Foto 3 - Animais do grupo controle e experimental na ēpoca do de smame.

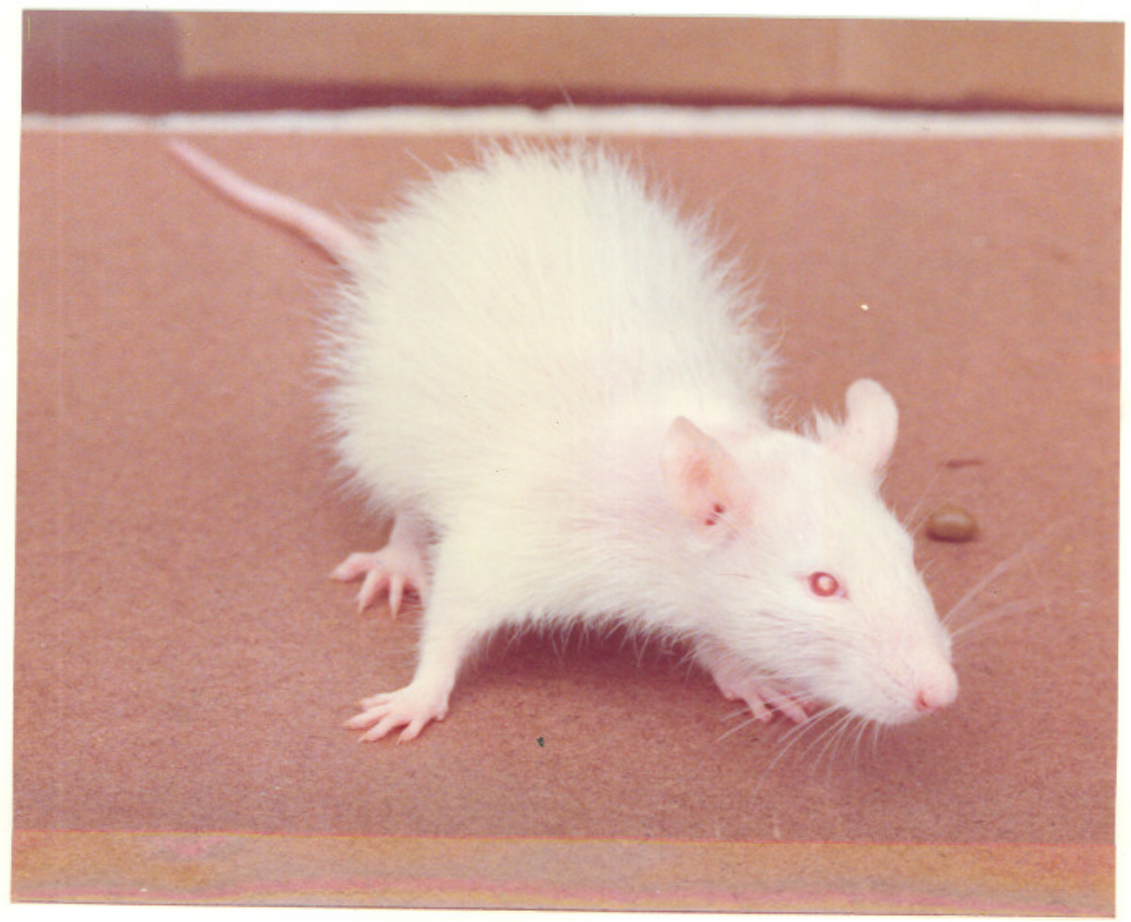

Foto 4 - Animal adulto do grupo de biomassa, apresentando man cha branca no olho. 
Vārios autores tem estudado esta fonte protēica, no estado natural em que é obtida, isolando-se a proteĩna, ou mes mo suplementando-a com os aminoācidos limitantes.

No estado natural, a biomassa possue as cēlulas intactas, que causam uma diminuicão do valor biolögico, pois nem todos organismos conseguem romper a parede celular, impedindo assim a sua utilização, fato que hoje justifica os problemas de diarrēias e desconforto gastrointestinal observados, quando da utilização das primeiras biomassas produzidas, atualmente, a tecnologia tem progredido neste campo, produzindo biomassa com celulas rompidas $(59)(83)(90)(94)(113)$.

o isolamento da proteîna é outro método que permite me lhor utilização da biomassa pois elimina os problemas relativos a ingestão de grandes quantidades de àcidos nucleicos, embora seu custo seja elevado. (73) (103) (113)

Finalmente, a suplementação com aminoācidos limitantes, permite um maior aproveitamento biolōgico atravēs do aumento da sintese protēica $(73)(98)(109)(111)$.

Com base no exposto, verificamos que esta fonte protēica poderā ser utilizada, embora estudos devam ser con tinuados, a fim de se esclarecer os problemas relativos a re produção. Ou seja, deve-se estabelecer qual etapa do desenvol vimento foi comprometida; se foi devido apenas a problemas decorrentes da desnutrição ou se foi devido a fatores exōgenos à biomassa, como por exemplo do processamento utilizado para sua obtenção; ou se foi por alguma caracteristica do pröprio microorganismo. 
8 - CONCLUSJES

Com base no exposto, podemos concluir:-

10) A ração de biomassa ao nîvel protēico de $10 \%$, em ensaio de curta duração, apresentou indices satisfatōrios de valor biolögico.

20) A ração de biomassa, ao nỉvel protēico de 10\%, em ensaio de gerações, não foi suficiente para manutenção dos animais atē a $3 a$. geração.

30) A ração de biomassa, ao nível protëico de $25 \%$, manteve os animais atē a 3a. geração, entretanto com diminuição grada tiva do valor biolögico.

40) A biomassa utilizada neste experimento como ūnica fonte protēica na ração, durante o estudo de gerações, apresen tou-se inferior à fonte protēica padrão de caseỉna, em relação aos indices de valor biológico testados. 
50) Nas condições experimentais deste trabalho, observamos pro blemas de reprodução nos animais machos; alimentados com fonte protëica de biomassa. 
9 - REFERENCIAS BIBLIOGRAFICAS*

1 - Abdel-hafez, A.M.; Mahmoud, S.A.Z.; El-SAWy, M.; RAMAdan, E.M. - Studies on protein production by yeasts. II Protein, non-protein nitroqen, and amino acid content of yeast strains. Zbl. Bakt., II Abt., 132:631-40, 1977.

2 - AHMAd, G. \& RAHMAN, M.A. - Effects of undernutrition and protein malnutrition on brain chemistry of rats. J.Nutr., Philadelphia, 105:1090-103, 1975.

3 - ALLEN, L.H. \& ZEMAN, F.J. - Influence of increased post natal food intake on body composition of progeny of protein - deficient rats. J. Nutr., Philadelphia, 101: $1311-8,1971$.

4 - AltSChUl, A.M. - The agricultural, scientific and economic basis for low-cost protein foods. In: MATELES, R. J. \& TANNENBAUm, S. R. Single cell protein. Massachussetts, M.I.T. Press, 1968. p.48-64.

5 - ashraf, M.; Vetter, R.L.; nissen, S.; graham, D.L. Nutritional evaluation of methanol-based yeast single cell protein in a multigeneration rat study. Nutr. Rep. Int., Los A1tos, 23(5):813-24, 1981.

\footnotetext{
* De acordo com as normas preconizadas pela ASSOCIAÇAO BRASILEI RA DE NORMAS TECNICAS (ABNT). As abreviaturas dos títulos de periódicos estão de acordo com World Medical Periodicals, 3. ed., New York, 1961.
} 
6 - ASPECTOS de nutricion y seguridad de las nuevas fuentes de proteinas para alimentacion de animales. Bol. GAP, New York, $\underline{4}(3): 12-20,1974$. |Norma nọ 15|.

7 - ASSESSMENT of the world food situation present and future (extracts from the papers of the United Nations World Food Conference). Food Nutr., Rome, I(1):7-43,1975.

8 - ASSOCIATION OF OFFICIAL ANALYTICAL CHEMISTS. Official methods of analysis. 11.ed. Washington, 1970. p.168 .

9 - Atallah, M.T.; Barbeau, I.S.; Pellett, P.L. - Metabolic and development changes in growing rats born to dams restricted in protein and/or energy intake. J. Nutr., Philadelphia, 107:650-5, 1977.

10 - BARBER, R.S.; BRAude, R.; MitChELL, K.G.; MYRES, A. W. The value of hidrocarbon-grown yeast as a source of protein for growing pigs. Brit. J. Nutr., London, $25: 285-94,1971$.

11 - BEATON, G.H. \& SWISS, L.D. - Evaluation of the nutritional quality of food supplies: prediction of "desirable" or "safe" protein calorie ratios. Amer. J. clin. Nutr., New York, 27:485-504, 1974.

12 - BENDER, A.E. \& DOELL, B.H. - Note on the determination of net protein utilization by carcass analysis. Brit. J. Nutr., London, 11:138-9, 1957.

13 - Bender, A.E. \& DOELL, B.H. - Biological evaluation of proteins: a new aspect. Brit. J. Nutr., London, 11: $140-8,1957$. 
14 - BENDER, A.E. \& DOELL, B.H. - Absence of toxic effects by food yeast on the rat. Brit. J. Nutr., London, 14 : $305-13,1960$.

15 - BhATTAChARJEE, J.K. - Microorganisms as potential sources of food. Advanc. appl. Microbiol., New York, 13:13961,1970 .

16 - BLOCK, R.J. \& BOLLING, D. - The aminoacids yielded by various yeasts after hydrolysis of the fat free material. A comparative investigation. Arch. Biochem., New York, 7:313-21, 1945 .

17 - BOWERING, J.; CALLOWAY, D.H.; MARGENS, S.; KAUFMANN, N.A. - Dietary protein level and uric acid metabolism in normal man. J. Nutr., Philadelphia, 100:249-61, 1969.

18 - BRENNER, S.; WODICKA, V.0.; DUNLOP, S.G. - Experimentation with dried yeast for use in army rations. J. Amer. diet. Ass., Chicago, 25:409-15, 1949 .

19 - BRESSANI, R. - The use of yeast in human foods. In: MATE LES, R.I. and TANNENBAUM, S.R. Single-cell protein, Massachussetts, M.I.T. Press, 1968. p.90-121.

20 - BRESSANI, R.; VALLE, L.U.; ELIAS, L.G. - Relacion entre el nitrogenio retenido por ratas, determinado por analisis corporal de nitrogeno y por medio de balance nitrogena do. Arch. Iatinoam.Nutr., Caracas, 26 (4):449-83, . 1976.

21 - BUNKER, H.J. - Sources of single cell protein: perspective and prospect. In: MATELES, R.I. \& TANNENBAUM, S. R. Single-cell protein, Massachussetts, M.I.T. Press, 1968. p. 67-78. 
22 - CANEPA, A.; PIEBER, M.; ROMERO, C.; TOHA, J.C. - A method for large reduction of the nucleic acid content of yeast. Biotechnol. Bioeng., New York, 14:173-7, 1972.

23 - CARNEIRO, W. - A indüstria de proteinas no Brasil. Bras. açucareiro, Rio de Janeiro, 64(6):34-9, 1967.

24 - CARneiro, W. - Economicidade da indūstria de leveduras. Bras. açucareiro, Rio de Janeiro, 64(7):16-23, 1967.

25 - CARTER, M.B. \& PHILlips, G.E. - The nutritive value of yeast proteins. Fed. Proc., Washington, 3:123, 1944.

26 - CAStro, A.C.; Sinskey, A.J.; TANnenbaum, S.R. - Reduction of nucleic acid content in yeast cells by bovine pancreatic ribonuclease treatment. Appl. Microbiol., Baltimore, 22:422-7, 1971 .

27 - CHIAO, J.S. \& PETERSON, W.H. - Yeasts-methionine and cystine contents. J. agric. Food Chem., Washington, $1: 1005-8,1953$.

28 - CLIFFORD, A.J. \& STORY, D.L. - Levels of purines in foods and their metabolic effects in rats. J. Nutr. Phila delphia, 106:435-42, 1976 .

29 - Cozzolino, S.M.F. - Valor biolögico da proteína da mistura de arroz e feijão, suplementada com metionina, cāicio e retinol. Ensaio em ratos alimentados ad libitum e com restrição. São Paulo. 1975.72 p. |Dissertação de Mestrado - Faculdade de Ciências Farmacēuticas - USP|.

30 - CULLEY, W.J. \& LINEBERGER, R.0. - Effect of undernutrition on the size and composition of the rat brain. J. Nutr., Philadelphia, 96:375-81, 1968 . 
31 - DABBAH, R. - Protein from microorganisms. Food Technol., Chicago, 24:659-66, 1970.

32 - EDOZIEN, J.C.; UDO, U.U.; YOUNG, V.R.; SCRIMSHAW, N.S. Effects of high levels of yeast feeding on uric acid metabolism of young men. Nature, London, 228: 180,1970 .

33 - ENSAYOS preclinicos de nuevas fuentes de proteinas. Bol. GAP, New York, $\underline{4}(3): 20-35,1974$. |Norma nọ 6|.

34 - EVANS, E. \& WITTY, R. - An assessment of methods used to determine protein quality. Wld. Rev. Nutr. Diet., Lon don, 32: $1-26,1978$.

35 - FOOd AND AgRiculture ORGANizATION OF THE UNITEd NATIONS . Nutrition Division Food policy and food service Amino-acid content of foods and biological data on proteins. F.A.0. Nutritional Studies, Roma (24), 1970. $285 \mathrm{p}$.

36 - enRIQUECIMIENTo de los alimentos. Desnutrición proteico-calörica. In: COMITE MIXTO FAO/OMS DE EXPERTOS EN NU TRICIÓN, 8., Ginebra, 1970. Informe. Ginebra, Organi zacion Mundial de la Salud, 1972. 131 p. IOMS Sērie de informes tēcnicos, 477; FAO Reuniones sobre nutri ciōn, 49|.

37 - NECESIDADES de energia y de proteinas. In: COMITE ESPECI AL MIXTO FAO/OMS DE EXPERTOS EN NECESIDADES DE ENERGIA $Y$ DE PROTEINAS, Roma, 1971. Informe, Roma, Organizaci ōn Mundial de la Salud, 1973. 138 p. |OMS Sērie de informes tëcnicos, 522; FAO Reuniones sobre nutriciōn, 52; Colecciōn FAO Alimentaciōn y nutriciōn, $7 \mid$. 
38 - FITZGERALD, J.F. \& FERDINANDUS, L.D. - Effect of maternal protein deprivation on in vitro neonatal intestinal function in rats. J. Nutr., Philadelphia, 105:1476-80, 1975 .

39 - FLORENTINO, R.F. \& BROQUist, H.P. - Production and nutritional evaluation of a high lysine baker's yeast. (Saccharomyces cerevisiae) in rats. J. Nutr., Philadelphia, 104:884-93, 1974 .

40 - FloRes, H.; SieRralta, W.; MONCKEBERG, F. - Triglyceride transport in protein-depleted rats. J. Nutr., Philadelphia, 100:375-9, 1970 .

41 - FOLCH, J.; LEES, M.; STANLEY, G.H.S. - A simple method for the isolation and purification of total lipides from animal tissues. J.biol. Chem., Baltimore, 226 : 497-509, 1957 .

42 - FUNDAÇÃo Instituto Brasileiro de Geografia e Estatistica Estudo Nacional de Despesa Familiar - ENDEF, Rio de Janeiro, 1977. 2 v.

43 - FUNK, C.; LYLE, W.G.; MC CASKEY, D. - The nutritive value of yeast, polished rice and white bread, as determined by experiments on man. J.biol. Chem., Baltimore, 27: $173,1916$.

44 - GoYCO, J.A. - Nitrogen balance of young adults consuming a deficient diet supplemented with Torula yeast and other nitrogenous products. J. Nutr., Philadelphia, 69: $49-57,1959$. 
45 - GoYco, J. A. - Studies on edible yeasts. II Growth and reproduction performance of rats fed on yeasts as sole source of protein. Puerto Rico J. publ. H1th trop. Med., New York, 23: 476-87, 1948a.

46 - GoYco, J.A. - A study of the relation between the liver protein regeneration capacity and the hepatic neurogenic activity of yeast proteins. J.Nutr., Philadelphia, 58 $: 299-308,1956$.

47 - GOYCO, J.A. \& ASENJO, C.F. - Net protein and growth -promoting values of three different types of yeast prepared under identical conditions. J. Nutr., Philadelphia, 38:517-26, 1949.

48 - GoYCO, J.A. \& ASENJO, C.F. - The net protein value of food yeast. J. Nutr., Philadelphia, 33:593-600, 1947.

49 - GROOT, A.P.; TIL, H.P.; PERON, V.J. - Safety evaluation of yeast grown on hydrocarbons. III. Two-year feeding and multigeneration study in rat with yeast grown on gas oil. Food Cosmet. toxicol., London, 9:787-80,1971.

50 - guanabara filho, A. - A rentabilidade da indüstria de le vedura-alimento. Bras. açucareiro, Rio de Janeiro, 64 (5) $: 19-25,1967$.

51 - GUIDELINE for human testing of supplementary food mixtures. In: TANNENBAUM, S.R. \& WANG, D. I. C. Single-cell protein II, Massachussetts, M.I.T. Press, 1975. p. 655-69. |PAG Guideline nọ 7 - Human Testing Procedures|. 
52 - GUIDELINE on the production of single-cell protein for human consumption. In: TANNENBAUM, S.R. \& WANG, D. I. C. Single-cell protein II, Massachussetts, M.I.T. Press, 1975, p.670-3. |PAG Guideline nọ 12 - Single-cell protein!.

53 - GUTHRIE, H.A. \& BROWN, M.L. - Effect of severe undernutrition in early life on growth brain size and composition in adult rats. J. Nutr., Philadelphia, 94:419-26, 1968.

54 - GYÖRGY, P.; ROSE, C.S.; TOMARELLI, R.M.; GOLDBLATT, H. Yeast in the production of dietary massive hepatic necrosis in rats. J. Nutr., Philadelphia, 41:265-78, 1950 .

55 - HAN, Y. W.; DUNLAP, C.E. \& CALLIHAN, C.D. - Single-cell protein from cellulosic wastes. Food technol., Chica go, 25:130-3, 1971 .

56 - HAWK, P.B.; SMITH, C.A.; HOLDER, R.0. - Bakers' yeast as food for man. Amer. J. Physiol., Baltimore, 48:199, 1919 .

57 - HEDENSKOG, G. \& EDDINGHAUS, L. - Reduction of the nucleic acid content of single-cell protein concentrates. Biotechnol. Bioeng., New York, 14:447-57, 1972.

58 - HENDERSON, J.F. - Purine Nucleotide Metabolism in Mammaliam Cells. Biochem. Soc. Trans., London, $\underline{3}$ : $1195-8,1975$.

59 - HUMPHREY, A.E. - Product outlook and technical feasibility of S.C.P. In: TANNENBAUM, S.R. \& WANG, D.I.C. Single-cel1 protein II, Massachussetts, M.I.T. Press, 1975, p. $1-23$. 
60 - instituto Adolfo LUTz, São Paulo - Normas analiticas do Instituto Adolfo Lutz. 2.ed. São Paulo, 1976. 371 p.

61 - Kenney, M.A. \& BARTON, E.B. - Malnutrition and fetal development in two generations of rats. Nutr. Rep. Int., Los Altos, 11(3):243-250, 1975.

62 - Kilberg, R. - The microbe as a source of food. Ann. Rev. Microbiol., Palo Alto, 26:427-65, 1972.

63 - Kinsela, J.E. \& SheTty, H.J. - Yeast proteins recovery, nutritional and funcional properties. Advanc. Exp. Med. Biol., New York, 107:797-825, 1978.

64 - KLAPKA, M.R.; DUBY, G.A.; PAVCER, P.L. - Torula yeast as a dietary supplement-study in acceptability by patients J. Amer. diet. Ass., Chicago, 34:1317-20, 1958.

65 - KWONG, E. \& BARNES, R.H. - Comparative contributions of dietary protein quality and quantity to growth during gestation, lactation and postweaning in the rat. J. Nutr., Philadelphia, 107:420-5, 1977.

66 - LINDAN, 0. \& WORK, E. - The amino-acid composition of two yeasts used to produce massive dietetic liver necrosis in rats. Biochemistry, New York, 48:22-34, 1951.

67 - Lipinsky, E.S. \& LitChfield, J.H. - Single-cell protein in perspective. Food Technol., Chicago, 28(5):16-23, 1974 .

68 - Litchfield, J.H. - Single-cell proteins. Food Technol., Chicago, 31(5):175-9, 1977. 
69 - LIU, T.Y. \& CHANG, Y.H. - Hydrolysis of proteins with p- toluensulfonic acid. J. biol. Chem., Baltimore, 246: $2842-8,1981$.

70 - LOESECKE, H.W. - Controversial aspects: yeast in human nutrition. J.Amer. diet. Ass., Chicago, 22:485-93, 1946 .

71 - LOMBARDI, B. - Pathogenesis of fatty liver. Fed. Proc., Washington, 24:1200-5, 1965 .

72 - LOURENÇO, E.J. - Influência da proteina da dieta sobre o desenvolvimento de örgãos de ratos. São Paulo, 1975, $99 \mathrm{p}$. ITese de doutoramento - Faculdade de Ciēncias Far macêuticas da Universidade de São Paulo|.

73 - MARIATH, J.G.R. - Comportamento biolögico da proteína isolada do resỉduo de cerveja - Estudo de alguns parâmetros bioquímicos e nutricionais. São Paulo, 1981, 166 p. ITese de doutoramento - Faculdade de Ciēncias Farmacêuticas da Universidade de São Paulol.

74 - MAUL, S.B.; SINSKEY, A.J.; TANNENBAUM, S.R. - New process for reducing the nucleic acid content of yeast. Nature, London, 228:181, 1970 .

75 - MILLER, S.A. - Nutritional factors in single-cell protein. In: MATELES, R.I. \& TANNENBAUM, S.R. Single-cell protein, Massachussetts, M.I.T. Press, 1968. p.79-89.

76 - MOORE, S. - On the determination of cystine as cisteic acid. J.biol. Chem., Baltimore, 238, 235-7, 1963.

77 - MORGAN, B.L.G. \& NAISMITH, D.J. - Effects on the products of conception of protein supplementation on the diets of rats. J.Nutr., Philadelphia, 107:1590-4, 1977. 
78 - MOURA, E.C.V. - Estudos nutricionais e bioquimicos de biomassa protēica obtida a partir de saccharomyces, sp., São Paulo, 1978, 173 p. Tese de Doutoramento - Faculda de de Ciências Farmacêuticas da Universidade de S. Paulol.

79 - MOURA, E.C.V. \& ZUCAS, S.M. - Estudo das alterações metabō licas em ratas, decorrentes da ingestão de proteina derivada de microorganismos (Biomassa - SCP), empregando como substrato a vinhaça (Saccharomyces, sp) e o melaço (Saccharomyces cerevisiae): I - Valor biolögico das fon tes protéicas durante 9 semanas a partir do desmame $e$ no período de gestação. Ciênc. Cult., São Paulo, 32 (7) : $787-8,1980$.

80 - MOURA, E.C.V. \& MENDES, A.A. - Efeitos da substituição do farelo de soja pela proteīna derivada da cana de açūcar pelo desenvolvimento de Saccharomyces cerevisiae em me 1 aço, na alimentação de frangos de corte. In: CONGRESSO BRASILEIRO DE AVICULTURA, Recife, 1981. 9 p.

81 - NATIONAL ACADEMY OF SCIENCES - Nutrient requeriments of laboratory animals. 2.ed. Washington, 1972. p.56-93. (Nutrient requeriments of domestic animals series, 10 ).

82 - NOBREgA, F.J.; TONETE, S.S.Q.; SARTOR, M.E.A.; CURY, P.R.

- Estudo experimental do crescimento placentārio na des nutrição protēico-calörica. J. Pediat., St. Louis, 46 (2): $82-92,1979$.

83 - OHTA, S.; MAUL, S.; SINSKEY, A.J.; TANNENBAUM, S.R. Characterization of heat-shock process for reduction of the nucleic acid content of Candida utilis. Appl. Microbiol., Baltimore, 22(3):415-21, 1971 .

84 - OLIVEIRA, E.V. - Proteīna derivada da cana de açūcar pe10 desenvolvimento de Saccharomyces cerevisiae em me 1 aço. In: CONGRESSO INTERNACIONAL DE NUTRIÇAOO, 11. , Rio de Janeiro - 1978. 31 p. 
85 - OLIVEIRA, J.D. - Desafio Brasileiro: alimentar adequadamen te 110 milhões de habitantes. Bol. ABIA/SAPRO, São Paulo, 26:43-53, 1976 .

86 - OMSTEDT, T.; VON DER DECKEN, A.; HEDENSKOG, G.; MOGREN, H. - Nutritive value of processed Saccharomyces cerevisiae, Scenedesmus obliquus and spirulina platensis as measured by protein synthesis in vitro in rat skeletal muscle. J. Sci. Food Agric., London, 24:1103-13, 1973.

87 - OSER, B.L. - Evaluation of the safety of new food products. In: MATELES, R.I. \& TANNENBAUM, S.R. Single-ce 11 protein. Massachussetts, M.I.T. Press, 1968. p. 15362 .

88 - OSER, B.L. - Guidelines for the evaluation of S.C.P. for human consumption. In: TANNENBAUM, S.R. \& WANG,D.I.C. Single-cel1 protein II, Massachussetts, M.I.T. Press, 1975. p. 484-8.

89 - Pellett, P.L. \& Young, V.R. - Nutritional evaluation of protein foods. The United nations University, 1980. $150 \mathrm{p}$.

90 - PEPPLER, H.J. - Industrial production of single-cell protein from carbohydrates. In: MATELES, R.J. \& TANNENBAUM,S.R. Single-cel1 protein, Massachussetts, M.I.T. Press, 1968. p.229-42.

91 - PINTO, G.F. \& ARAUJO NETO, J.S. - Limits for single-cell protein utilization in human feeding. Arch. latinoam. Nutr., Caracas, 22(1):49-63, 1972. 
92 - POKROVSKY, A. - Toxicological studies on single-cell proteins. In: MATELES, R.I. \& TANNENBAUM, S.R. Singlecel1 protein, Massachussetts, M.I.T. Press, 1968. p. 163-5.

93 - POKROVSKY, A. - Some results of SCP medico-biological investigations. In: TANNENBAUM, S.R. \& WANG, D.I.C. Single-cell protein II, Massachussetts, M.I.T. Press, 1975. p. 475-84.

94 - REED, G. \& PEPPLER, H.J. - Yeast technology. Westport AVI, 1973. $378 \mathrm{p}$.

95 - RHA, C. - Utilization of single-cell protein for human food. In: TANNENBAUM, S.R. \& WANG, D.I.C. Single-cel? protein II, Massachussetts, M.I.T. Press, 1975. p.587602 .

96 - ROBERTS, M.M.H. \& ZEMAN, F.J. - Effects of protein deficiency pair-feeding, or diet suppiementation on maternal, fetal and placental growth in rats. J.Nutr., Philadelphia, 107:973-82, 1977.

97 - SAlES, A.M.; MEnezes, T.J.B. de, ARAKAKI, T. - Produção de biomassa protēica em melaço de cana de açūcar Coletānea do Inst. Tecnol. Alimentos, Campinas, 7:97105,1976 .

98 - SCRIMSHAW, N.S.; BRESSANI, R.; WILSON, D.; BEHAR, M. Al1-vegetable protein mixtures for human feeding. $X$. Effect of Torula yeast on protein quality of INCAP Vegetable Mixture 9. Amer. J. clin. Nutr., New York, $11,537-42,1962$. 
99 - SCRIMSHAW, N.S. - Single-cell protein for human consumption. An overview. In: TANNENBAUM, S.R. \& WANG, D.I.C. Singlecell protein II, Massachussetts, M.I.T. Press, 1975. p. $24-5$.

100 - SCHIMSHAW, N.S. - Conceptual basis of the world hunger program. Food Nutr. Bu11., New York, I (4):1-2, 1979.

101 - SHACKLADY C.A. - Microbiological protein as a food and feed ingredient. Food Manuf., London, 44:36, 1969.

102 - SHACKLADY, C.A. - Value of S.C.P. for animals. In: TANNENBAUM, S.R. \& WANG D.I.C. Single-cell protein II, Massachussetts, M.I.T. Press, 1975. p. 489-504.

103 - SHETTY, K.J. \& KINSELLA, J.E. - Preparation of yeast protein isolate with low nucleic acid by succinylation. J. Food Sci., Chicago, 444:633-8, 1979.

104 - SINSKEY, A.J. \& TANNENBAUM, S.R. - Removal of nucleic acids in S.C.P. In: TANNENBAUM, S.R. \& WANG, D.I.C. Single-cell protein II, Massachussetts, M.I.T. Press, 1975. p. 158-78.

105 - SMITH, A.W. - El ratōn. S.L.p., Organizaciōn Panamerica na de la Salud, s.d. 122 p. ISerie de monografias c entificas y tëcnicas, 3/. 2.ed. Rio de Janeiro, 1976.

106 - SNYDER, H.E. - Microbial sources of protein. Advanc.Food Res., New York, 18:85-137, 1970.

107 - STEWART, J.M. \& YOUNG, J. - Solid phase peptide synthesis.

Freeman W.H. and Company, San Francisco, 1969, p.53-4. 
108 - STEWART, R.J.C. \& SHEPPARD, H.G. - Protein-calorie deficiency in rats. Growth and reproduction. Brit.J. Nutr.. London, 25:175-80, 1971.

109 - SURE, B. - Biological value of food yeast proteins and their role as suplements to the proteins of the cereal grains. J. Amer. diet. Ass., Chicaqo, 22:1146,1946 .

110 - SURE, B. - Dietary requirements for fertility and lactation XXXIII. Brewers' and cultured food yeasts as sources of proteins and the vitamin B complex for growth, reproduction and lactation. J. Amer. diet. Ass., Chicago, 22:766-9, 1946.

111 - SURE, B. - The nature of the supplementary value of the proteins in milled corn meal and milled wheat flour with dried food yeast. J. Nutr., Philadelphia, 36:5973,1948 .

112 - SURE, B. \& HOUSE, F. - Protein utilization of various dried food yeasts. Arch. Biochem., New York, 20:55-8, 1949 .

113 - TANnenbaum, S.R. - Factors in the processing of single cell protein. In: MATELES, R.I. \& TANNENBAUM, S.R. Single-cell protein, Massachussetts, M.I.T. Press, 1968. p.343-52.

114 - tannenbaum, S.R. - Single-cell protein, food of the future. Food Technol., Chicago, 25:962-6, 1971.

115 - TANnenbaum, S.R. - A quest for protein and a quest for safety. Food Technol., Chicago, 30:76-80, 1976. 
116 - THAYSEN, C.A. - Value of microorganisms in nutrition (food yeast). Nature, London, 151:406, 1943.

117 - UDO, U.; YOUNG, V.; EDOZIEN, J.; SCRIMSHAW, N. S. Evaluation of Torula yeast for human consumption. Fed. Proc., Washington, 28:807-10, 1969.

118 - Vananuvat, P. \& Kinsella, J.E. - Aminoacid composition of protein isolates from Saccharomyces fragilis. J. agric. Food chem., Washington, 23(3):595-7, 1975.

119 - VANANUVAT, P. - Value of yeast protein for poultry feeds. CRC Crit. Rev. Food Sci. Nutr., Cleveland $9(4): 325-43$, 1977.

120 - VICKERY, J.R. - Possible developments in the supply and utilization of food in the next 50 years. Food Technol., Chicago, 25:619-24, 1971.

121 - WASLIEN, C.I.; CALLOWAY, D.H.; MARGEN, S. - Uric acid production of men fed graded amounts of egg protein and yeast nucleic acid. Amer. J. clin. Nutr., New York, $21: 892-7,1968$.

122 - WASLiEN. C.I.; CALLOWAy, D.H.; MARGEN, S.; COSTA, F. Uric acid levels in men fed algae and yeast as protein sources. J. Food Sci., Chicago, 35:294-8, 1970.

123 - WASLIEN, C.I. - Unusual sources of protein for man. CRC Crit. Rev. Food Sci. Nutr., Cleveland, 6⑴:77-151, 1975.

124 - WATSON, J. - New Protein Food. Nutrition(Lond.), London, $28: 249-54,1973$. 
125 - WILKS, S.S. Apud: MORRISON, D.F. Multivariate statistical methods, New York, McGraw-Hi11, 1967. p.197.

126 - WINIK, M. - Nutrition pre-and postnatal development, New York, Plenum, 1979. 496 p.

127 - YOUNG, V.R. \& SCRIMSHAW, N.S. - Clinical studies on the nutritional value of single-cell proteins. In: TANNENBAUM, S.R. \& WANG, D.I.C. Single-cell protein II, Massachussetts, M.I.T. Press, 1975. p.564-86.

128 - ZAMENHOF, S.; GUTHRIE, D.; CLARKSON, D. - Study of possible correlations between body weights and brain parameters in neonatal and mature rats. Biol. Neonate, Base1, 24:354-62, 1974 . 


\section{SUMMARY}

The biological value of the proteins of Saccharomyces cerevisiae grown in sugar cane molasses was studied in rats during 3 generations.

The animals were fed two levels of yeast protein either $10 \%$ or $25 \%$ and compared with casein bed controls.

In the first generation the PER and body weight were significantly lower for the animals receiving the yeast in their diet. In the $2^{\text {rd }}$ and $3^{\text {rd }}$ generation the growth was retarded even more in relation to what had been observed for the first one, specially at $10 \%$ protein level. A decreased male fertility was also observed at litter born from rats bed either $10 \%$ or $25 \%$ protein.

The digestibility for casein was $90 \%$ and $80 \%$ for single cell protein. 